
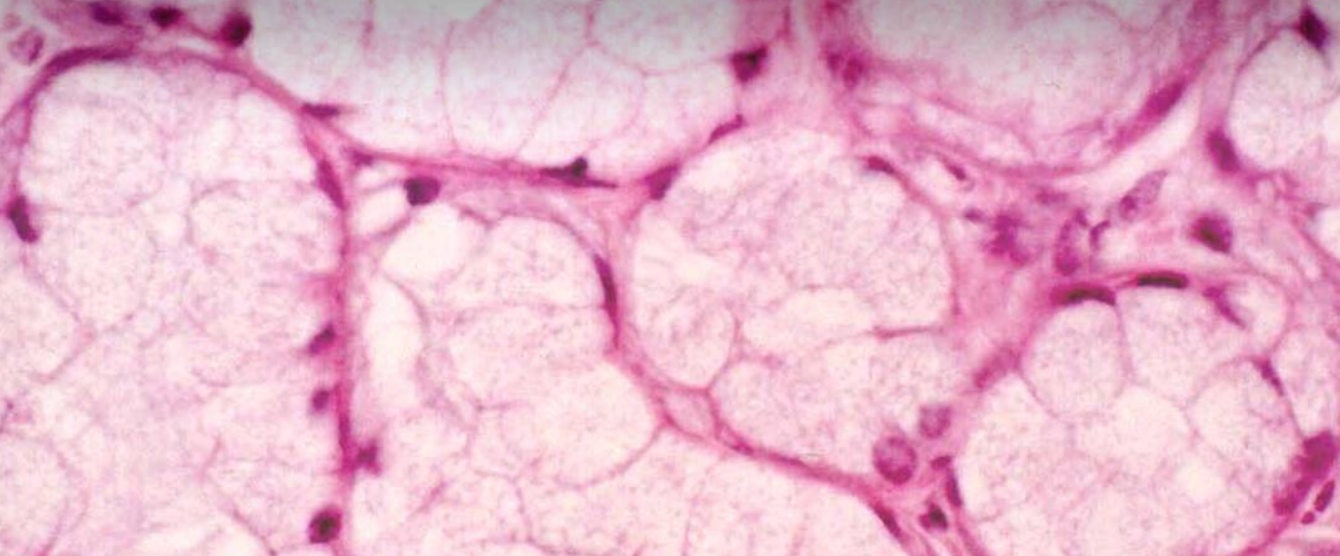

Alterações HistológiCAS dA GLÂNDULA SUBLINGUAL Humana COM A IDADE. ESTUdO MORFOMÉTRICO
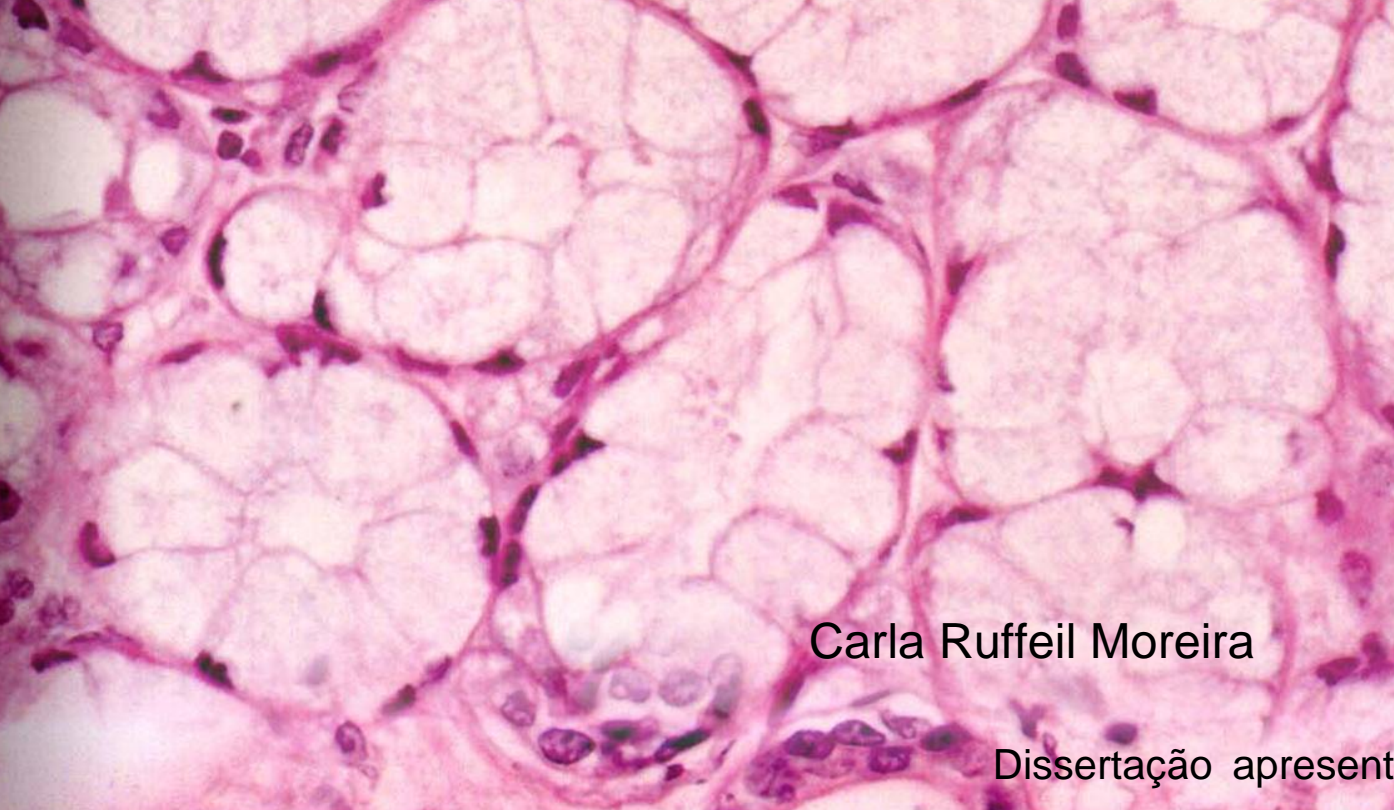

Carla Ruffeil Moreira

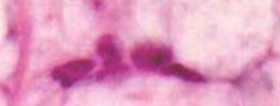

(4)
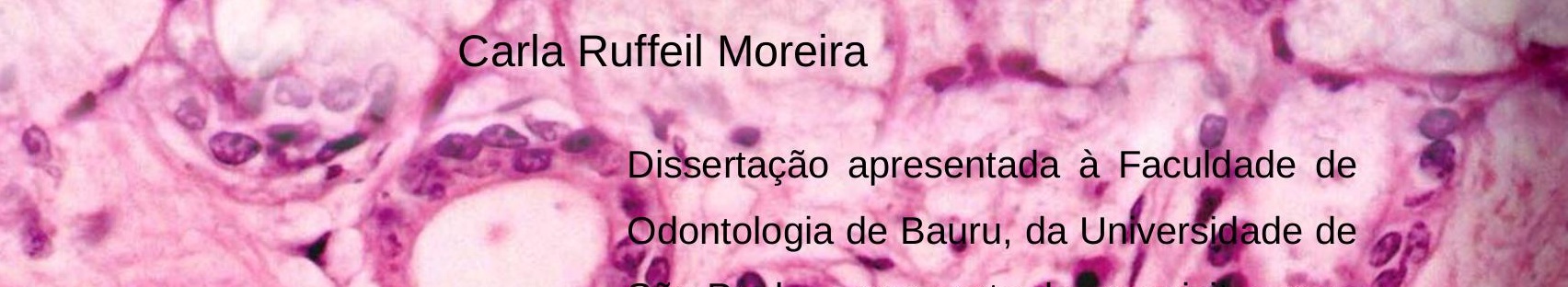

(2) Dissertação apresentada à Faculdade de Odontologia de Baýru, da Universidade de Sẫo Paulo, como parte đos requisitos para
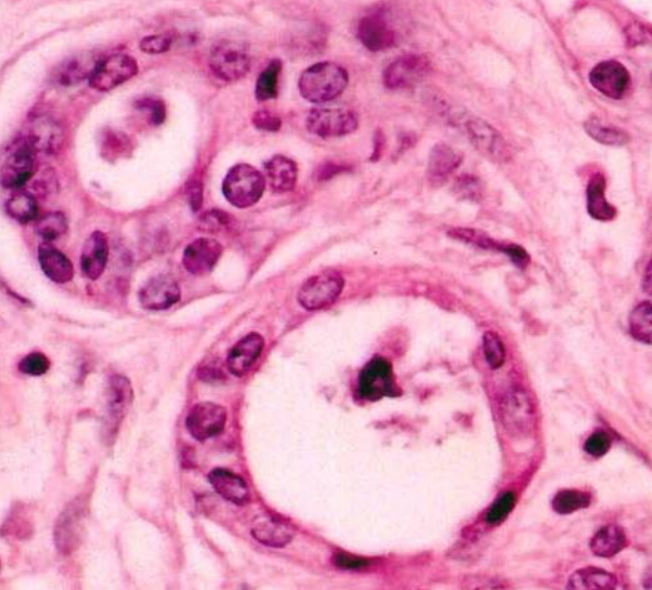

- 25 obtenção do sítulo de Mestre êm - Odontologia, área de Estomatologia.

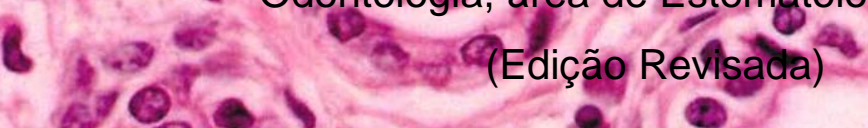

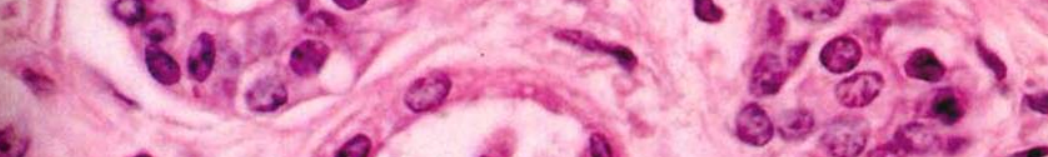

168.

$4 x^{2}$

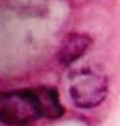

\%

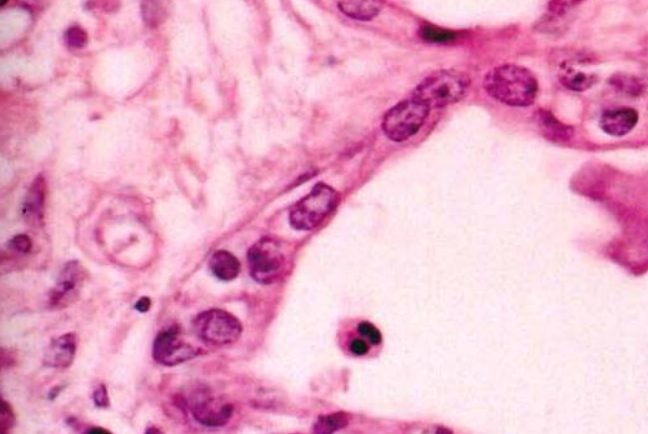

i
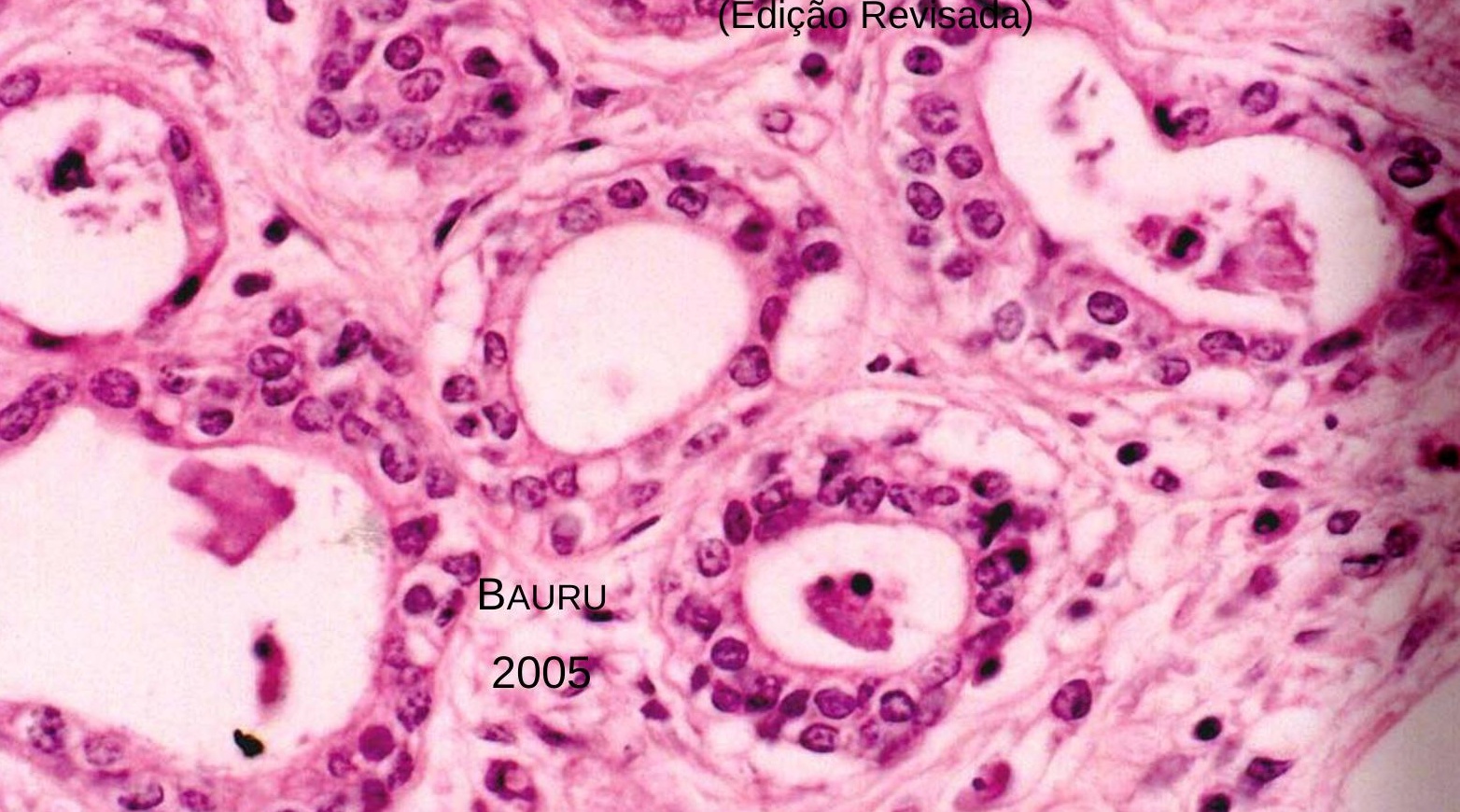

.

1.90
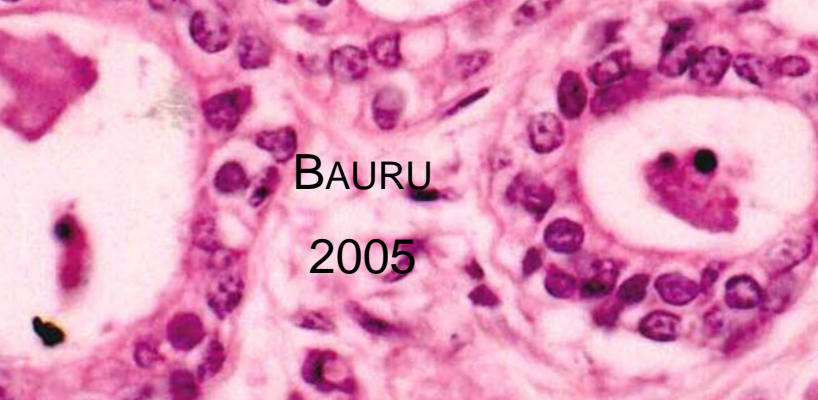

บ.6.

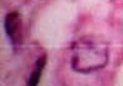

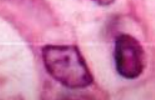

1 $4{ }^{3}$ 


\section{ALterações Histológicas dA GLÂNDULA SUBLINGUAL HUMANA COM A IDADE. ESTUDO MORFOMÉTRICO}

Carla Ruffeil Moreira

Dissertação apresentada à Faculdade de Odontologia de Bauru, da Universidade de São Paulo, como parte dos requisitos para obtenção do título de Mestre em Odontologia, área de Estomatologia.

Orientador: Prof. Dr. José Humberto Damante (Edição Revisada)

BAURU 
Moreira, Carla Ruffeil

M813a Alterações histológicas da glândula sublingual humana com a idade. Estudo morfométrico /Carla Ruffeil Moreira - Bauru, 2005.

74p; il.; $30 \mathrm{~cm}$

Dissertação (Mestrado) - Faculdade de Odontologia de Bauru. USP.

Orientador: Prof. Dr. José Humberto Damante

Autorizo, exclusivamente para fins acadêmicos e científicos, a reprodução total ou parcial desta dissertação, por processos fotocopiadores e/ou meios eletrônicos.

Assinatura do autor:

Data: / 2005.

Comitê de Ética em Pesquisa da FOB

No. do Protocolo: 606/03

Data: 18 de março de 2003. 


\section{Universidade de São Paulo \\ Faculdade de Odontologia de Bauru}

Al. Dr. Octávio Pinheiro Brisolla, 9-75 - Bauru-SP - CEP 17012-901 - C.P. 73

PABX (0XX14)235-8000 - FAX (0XX14)223-4679

Pos-Craduafăo

e-mail: posgrad@fob.usp.br -Fone: (0XX14)235-8223

\section{FOLHA DE APROVAÇÃO}

Dissertação apresentada e defendida por

CARLA RUFFEIL MOREIRA

e aprovada pela Comissão Julgadora

em 25 de abril de 2005.

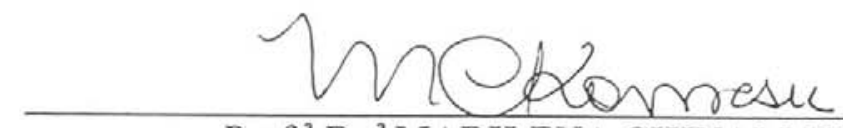

Prof. ${ }^{a}$ Dr. ${ }^{a}$ MARILENA CHINALI KOMESU

Faculdade de Odontologia de Ribeirão Preto - USP
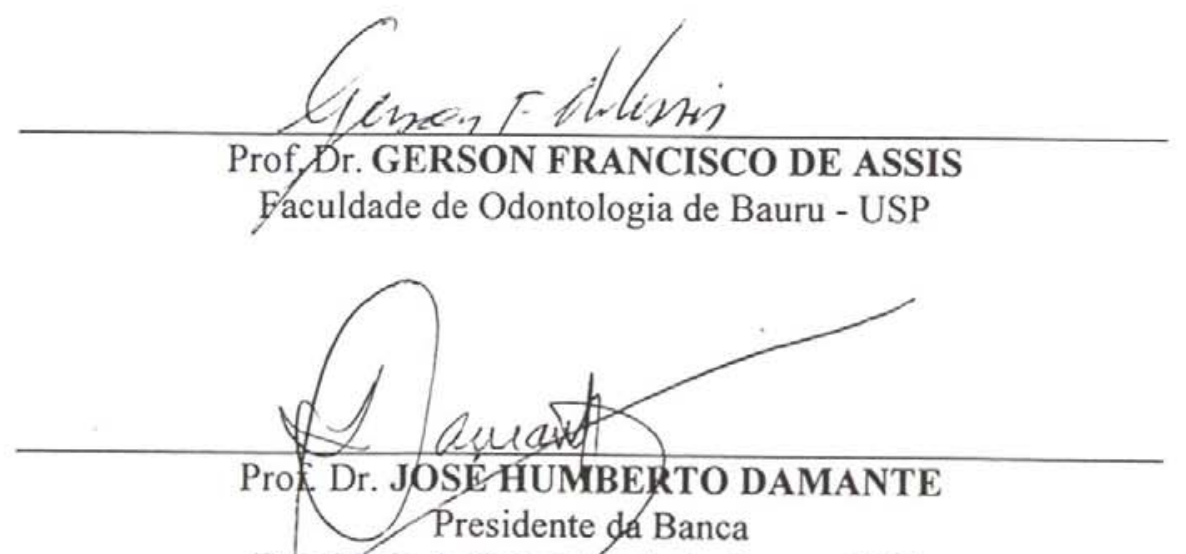

Faculdade de Odontologia de Bauru - USP

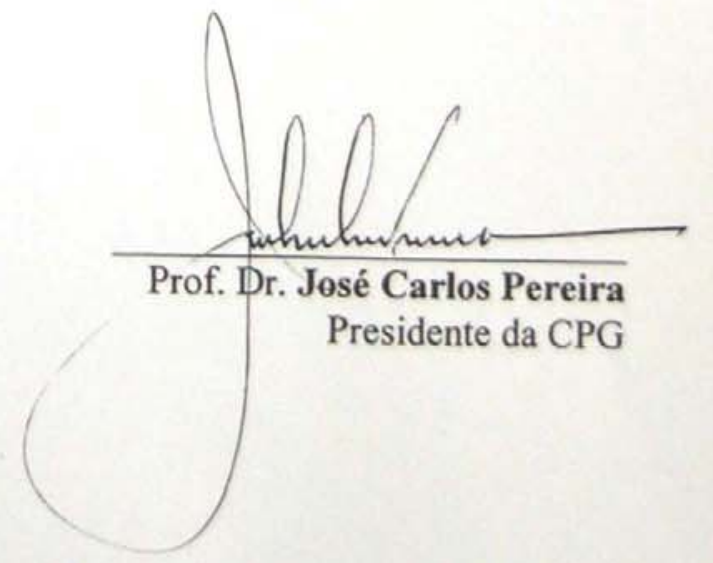




\section{CARLA Ruffeil MoReIRA}

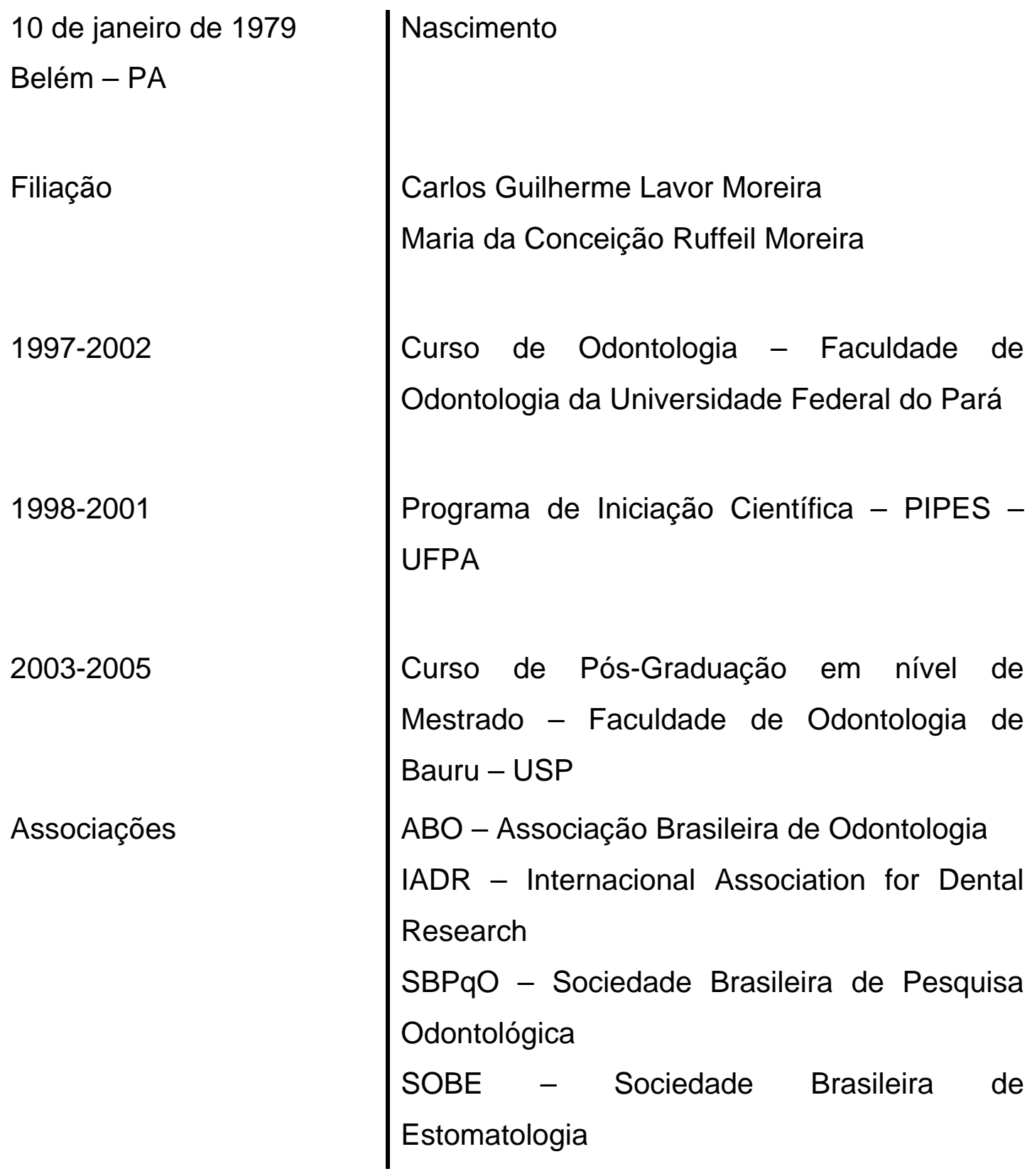


Aos meus pais,

irmão e família. 


\section{Ao Prof. Dr. José Humberto Damante}

Além do profissionalismo admirável, o caráter e a humildade fazem com que sua orientação não se limite a trabalhos científicos. Pela dedicação peculiar, entrega e sensibilidade, que o tornam esse ser humano,

MINHA SINCERA GRATIDÃO

\section{Ao Prof. Dr. Rumio Taga}

O incentivo e a solicitude fizeram com que, através de colocações precisas e oportunas, sua orientação se tornasse um privilégio.

MEU AGRADECIMENTO ESPECIAL 


\section{AGRADECIMENTOS}

À Faculdade de Odontologia de Bauru, na pessoa de sua diretora, Profa. Dra. Maria Fidela de Lima Navarro.

À Comissão de Pós-graduação, na pessoa de seu coordenador, Prof. Dr. José Carlos Pereira.

À Fundação de Amparo à Pesquisa do Estado de São Paulo - FAPESP, pelo investimento através da bolsa de mestrado (02/11883-6).

Aos professores e funcionários do Departamento de Estomatologia (Disciplinas de Radiologia, Estomatologia e Cirurgia), Profa. Dra. Ana Lúcia Álvares Capelozza, Prof. Dr. Eduardo Sant'Ana, Profa. Dra. Izabel Regina Fischer Rubira-Bullen, Prof. Dr. Júlio de Araújo Gurgel, Prof. Dr. Luiz Eduardo Montenegro Chinellato, Prof. Dr. Osny Ferreira Júnior, Prof. Dr. Paulo Perri, Camila Medina, David Almeida, Fernanda Cavalari, Josieli Farinha, José Messias, Marília Gião, Roberto Sales, Walderez Alves.

Aos professores e funcionários do Departamento de Ciências Biológicas (Disciplina de Histologia), Prof. Dr. Antônio Carlos Marconi Stipp, Prof. Dr. Gerson Francisco de Assis, Daniele Ceolin, Aldivina da Silva, Tânia Cestari, Beonildes Terezinha Ruiz.

Aos professores e funcionários do Departamento de Estomatologia (Disciplina de Patologia), Prof. Dr. Alberto Consolaro, Prof. Dr. Antônio Taveira, Profa. Dra. Denise Oliveira, Profa. Dra. Vanessa Lara, Maria Cristina Felipe, Fátima Silveira, Valdir João Afonso.

Aos amigos do curso de Pós-graduação (mestrado), Etiene Munhoz, Ligia Schmitd, Marcelo Zanda, Márcia Malmström e Renato Yaedú.

Aos colegas do curso de Pós-graduação (doutorado), Cássia Rubira, Cláudio Xavier, Eduardo Gonçales, Fernando Giglio, Flávio Amado e Luís Fernando Sant'Ana.

À Profa. Dra. Luciana Reis de Azevedo.

Ao Prof. Dr. José Roberto Lauris.

Aos funcionários do Serviço de Verificação de óbitos da Capital (SVOC). 
Aos profissionais do Setor de Cirurgia Buco-maxilo-facial do Hospital das Clínicas da Faculdade de Medicina da Universidade de São Paulo.

A todos os demais funcionários da Faculdade de Odontologia de Bauru. Às professoras da Universidade Federal do Pará, Profa. Dra. Cecy Martins Silva e Profa. Dra. Regina Feio Barroso, pela orientação durante a iniciação científica.

Aos professores da Universidade Federal do Pará, Prof. Armando Ferreira, Prof. Érick Pedreira, Prof. Dr. Fabrício Tuji, Profa. Flávia Pontes, Prof. Hélder Pontes e Prof. Dr. João Pinheiro, pelo incentivo constante.

Às amigas Ana Raquel Benetti, Graziella Danin, Ligia Schmitd e Tatiane Mota, pela convivência diária.

Aos amigos que, apesar de distância, se fazem presentes... Bruna Aquino Ilana Levy, Karla Lobato, Kleber Vieira, Mariella Braga, Nathália Cunha, Rodrigo Matoso, Rodrigo Salim e Tatiana Athayde.

Aos amigos Adilson Furuse, Alex Pozzobon, Augusto Bodanezi, Ana Carolina Leão, Angélica Hannas, Luciana Marocchio, Patrícia Andrade e a todos que, direta ou indiretamente, contribuíram para a realização deste trabalho. 


\section{SUMÁRIO}

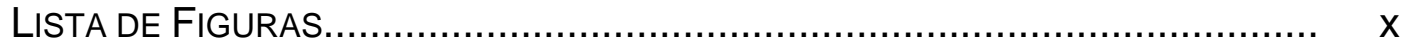

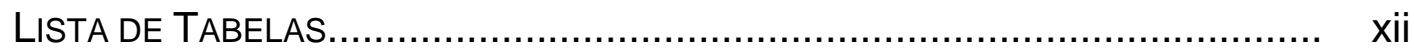

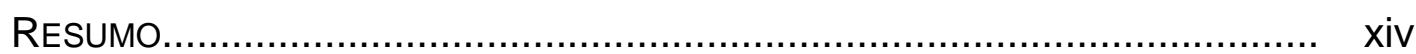

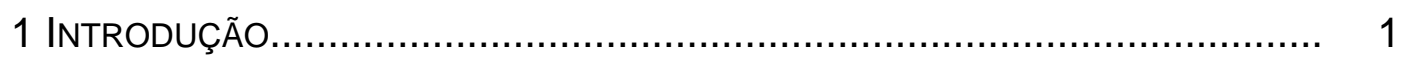

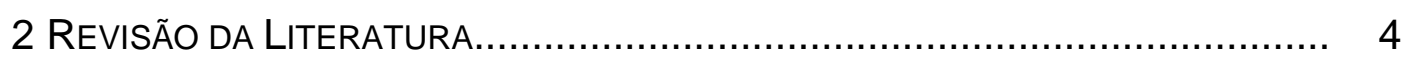

2.1 Trabalhos específicos............................................................ 5

2.2 Efeitos do envelhecimento nas glândulas salivares.......................... 6

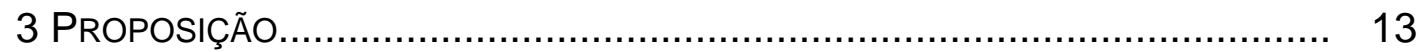

4 MATERIAL E MÉTODOS................................................................. 15

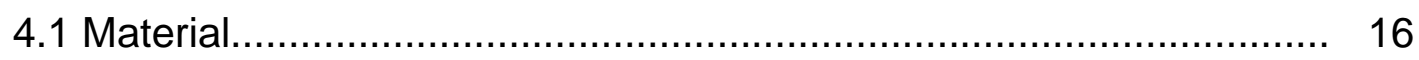

4.1.1 Obtenção das glândulas sublinguais humanas............................ 16

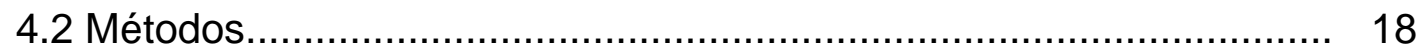

4.2.1 Procedimentos histológicos.................................................. 18

4.2.2 Análise morfométrica......................................................... 19

4.2.2.1 Avaliação da densidade da glândula sublingual........................ $\quad 19$

4.2.2.2 Determinação da retração provocada pelo processamento

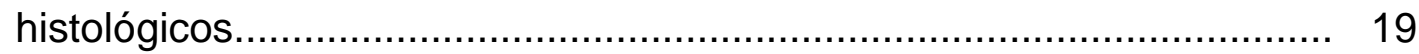

4.2.2.3 Estimativa do volume glandular processado........................... 20

4.2.2.4 Sistema-teste utilizado nas avaliações morfométricas................. 20

4.2.2.5 Casualização dos campos microscópicos................................... 21

4.2.2.6 Determinação da densidade de volume (Vvi) de cada componente glandular................................................................ 22

4.2.2.7 Determinação do coeficiente de variação da média.................... 24

4.2.2.8 Determinação do volume absoluto de cada estrutura.................. 24

4.2.3 Critérios adotados nas quantificações........................................... 24

4.2.4 Análise estatística............................................................... 32

5 RESULTADOS.......................................................................... 33

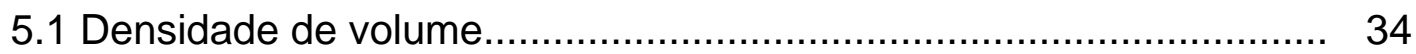

5.1.1 Densidade de volume de ácinos............................................. 34 
5.1.2 Densidade de volume de ductos.

5.1.3 Densidade de volume de estroma..................................... 37

5.1.4 Densidade de volume de tecido adiposo............................ 38

5.1.5 Densidade de volume de septos...................................... 39

5.1.6 Densidade de volume de parênquima e de estroma total............. 40

5.2 Comparação da densidade de volume entre gêneros..................... 41

5.3 Coeficiente de variação (Erro) .......................................... 42

5.4 Volume glandular e volume absoluto por componente.................. 43

5.4.1 Relação parênquima/estroma e ácinos/ductos......................... 45

6 DıSCUSSÃO..................................................................... 47

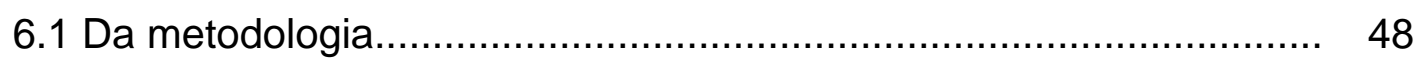

6.1.1 Da casualização dos campos microscópicos............................ 48

6.1.2 Dos critérios adotados nas quantificações.................................. 49

6.2 Dos resultados............................................................... 50

6.2.1 Da densidade de volume ................................................. 50

6.2.1.1 Densidade de volume de ácinos..................................... 50

6.2.1.2 Densidade de volume de ductos......................................... 51

6.2.1.3 Densidade de volume de estroma....................................... 52

6.2.1.4 Densidade de volume de tecido adiposo............................ 53

6.2.1.5 Densidade de volume de septos......................................... 53

6.2.1.6 Densidade de volume de parênquima e de estroma total.......... 54

6.2.2 Da comparação entre gêneros........................................... 54

6.2.3 Do coeficiente de variação (Erro)....................................... 55

6.2.4 Dos volumes glandular e absoluto por componente.................... 56

6.2.4.1 Da relação parênquima/estroma e ácinos/ductos.................... 58

7 CONCLUSÕES.................................................................. 59

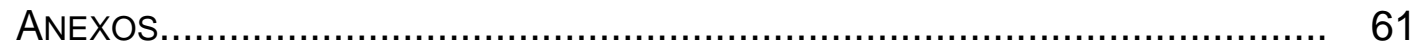

REFERÊNCIAS BIBLIOGRÁFICAS ..................................................... 67

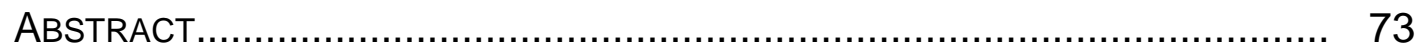




\section{LISTA DE FIGURAS}

FIGURA 1 - Esquema mostrando as secções transversais da glândula sublingual durante a macroscopia.

FIGURA 2 - Retículo de integração II Zeiss

FIGURA 3 - Esquema de casualização sistemática que representa um corte de glândula sublingual. Os quadrados preenchidos representam os campos a serem contados.

FIGURA 4 - Determinação da densidade de volume de cada estrutura pela contagem de pontos. Esquema ilustrativo.

FIGURA 5 - Ácinos mucosos da glândula sublingual. Mulher de 47 anos. (H.E.; aumento 550X).

FIGURA 6 - Ducto excretor interlobular $\left({ }^{*}\right)$ da glândula sublingual. Mulher de 39 anos. (H.E.; aumento 550X)...

FIGURA 7 - Estruturas ductiformes e tecido conjuntivo (setas) em sublingual atrófica. Homem de 70 anos. (H.E.; aumento 550X).

FIGURA 8 - Células do sangue e vasos (setas) em glândula sublingual. Mulher de 39 anos. (H.E.; aumento 550X).

FIGURA 9 - Infiltrado inflamatório $\left(^{*}\right)$ em glândula sublingual. Mulher de 73 anos. (H.E.; aumento 550X)

FIGURA 10 - Epitélio do soalho bucal e tecido conjuntivo subjacente. Mulher de 59 anos. (H.E.; aumento 550X).

FIGURA 11 - Interface entre glândula sublingual $\left(^{*}\right)$ e glândula submandibular ( $\bullet$ ). Homem de 40 anos. (H.E.; aumento 128X)..

FIGURA 12 - Espaço vazio $\left(^{*}\right)$ em glândula subingual. Mulher de 59 anos. (H.E.; aumento 550X)....

FIGURA 13 - Células adiposas (setas) entre ácinos da glândula sublingual. Homem de 30 anos. (H.E.; aumento 550X)..

FIGURA 14 - Substituição por tecido adiposo (setas) e tecido conjuntivo $\left({ }^{*}\right)$. Homem de 85 anos. (H.E.; aumento 550X).

FIGURA 15 - Septo interlobular (*) em glândula sublingual. Homem de 11 anos. (H.E.; aumento 550X). 
FIGURA 16 - Cápsula da glândula sublingual (*). Homem de 11 anos. (H.E.; aumento 550X)

FIGURA 17 - Autólise acinar (*) em glândula sublingual. Homem de 70 anos. (H.E.; aumento 550X).

FIGURA 18 - Valores médios da densidade de volume dos componentes glandulares nos três grupos estudados.

FIGURA 19 - Distribuição da densidade de volume de ácinos dos indivíduos segundo a idade.

FIGURA 20 - Distribuição da densidade de volume de ductos dos indivíduos segundo a idade.

FIGURA 21- Distribuição da densidade de volume de estroma dos indivíduos segundo a idade.

FIGURA 22- Distribuição da densidade de volume de tecido adiposo dos indivíduos segundo a idade

FIGURA 23 - Distribuição da densidade de volume de septos dos indivíduos segundo a idade.

FIGURA 24 - Valores médios da densidade de volume de parênquima e de estroma total nos três grupos estudados.

FIGURA 25 - Distribuição da densidade de volume de parênquima dos indivíduos segundo a idade.

FIGURA 26 - Distribuição da densidade de volume de estroma total dos indivíduos segundo a idade

FIGURA 27 - Valores médios da densidade de volume dos vários componentes glandulares nos gêneros masculino e feminino.

FIGURA 28 - Distribuição do volume glandular dos indivíduos segundo a idade.

FIGURA 29 - Distribuição da relação parênquima/estroma dos indivíduos segundo a idade.

FIGURA 30 - Distribuição da relação ácinos/ductos dos indivíduos segundo a idade. 
TABELA 1 - Distribuição dos indivíduos da amostra segundo a idade e o gênero.

TABELA 2 - Média da densidade de volume de ácinos nos três grupos estudados.

TABELA 3 - Diferenças percentuais entre as médias da densidade de volume de ácinos dos três grupos estudados.

TABELA 4 - Média da densidade de volume de ductos nos três grupos estudados.

TABELA 5 - Diferenças percentuais entre as médias da densidade de volume de ductos dos três grupos estudados.

TABELA 6 - Média da densidade de volume de estroma nos três grupos estudados.

TABELA 7 - Diferenças percentuais entre as médias da densidade de volume de estroma dos três grupos estudados.

TABELA 8 - Média da densidade de volume de tecido adiposo nos três grupos estudados.

TABELA 9 - Diferenças percentuais entre as médias da densidade de volume de tecido adiposo dos três grupos estudados.

TABELA 10 - Média da densidade de volume de septos nos três grupos estudados.

TABELA 11 - Diferenças percentuais entre as médias da densidade de volume de septos dos três grupos estudados.

TABELA 12 - Média da densidade de volume de parênquima e de estroma total nos três grupos estudados

TABELA 13 - Média da densidade de volume dos vários componentes glandulares nos gêneros masculino e feminino.

TABELA 14 - Coeficiente de variação médio dos componentes glandulares nos três grupos estudados.

TABELA 15 - Volume glandular médio $\left(\mathrm{cm}^{3}\right)$ nos três grupos estudados. 
TABELA 16 - Volume glandular médio $\left(\mathrm{cm}^{3}\right)$ nos gêneros masculino e feminino

TABELA 17 - Volume absoluto médio $(\mathrm{VT})$, em $\mathrm{cm}^{3}$, dos vários componentes glandulares nos três grupos estudados.

TABELA 18 - Média da relação parênquima/estroma nos três grupos estudados.

TABELA 19 - Média da relação ácinos/ductos nos três grupos estudados.

TABELA 20 - Volume glandular médio $\left(\mathrm{cm}^{3}\right)$ nos três grupos estudados considerando o grupo I com 15 indivíduos. 
Resumo 


\section{RESUMO}

O objetivo deste estudo foi avaliar as modificações morfológicas quantitativas em glândulas sublinguais humanas relacionando-as com a idade cronológica e o gênero. Noventa glândulas sublinguais direitas de cadáveres humanos foram distribuídas por gênero e grupo etário para a análise morfométrica dos vários componentes glandulares e do volume glandular. Os indivíduos de idades variando entre 7 meses e 92 anos foram divididos nos grupos I (0-30 anos, $n=25)$, II (31-60 anos, $n=30)$ e III (61-92 anos, $n=35)$. As contagens foram realizadas em microscópio óptico, usando objetiva 40x e ocular $\mathrm{Kpl}$ 8x contendo um retículo de integração constituído por 100 pontos simetricamente distribuídos. A densidade de volume de ácinos, ductos, estroma, tecido adiposo e septos foi avaliada em 51 campos histológicos por glândula, selecionados por amostragem sistemática. A análise dos resultados mostrou diminuição de $56,35 \%$ na densidade de volume de ácinos $(p<0,0001)$ e $35 \%$ na de septos $(p<0,0001)$ e, paralelamente, a ocorrência de aumento de $59,79 \%, 517,82 \%$ e $738,36 \%$ na densidade de volume de ductos $(p=0,0275)$, estroma ( $p<0,0001)$ e tecido adiposo $(p<0,0001)$, respectivamente. O volume glandular diminuiu, em média, 33,73\% ( $p=0,0005)$. Não houve diferença estatisticamente significante entre gêneros $(p>0,05)$. Ocorreu a diminuição do parênquima e o aumento do estroma com o envelhecimento. 


\section{Introdução}




\section{INTRODUÇÃO}

A glândula sublingual é a menor das três glândulas salivares maiores e está situada sob a mucosa que reveste o soalho da boca. Algumas condições sistêmicas podem estar associadas com tumefações não neoplásicas de glândulas salivares maiores, como: diabete melito, alcoolismo, amiloidose, sarcoidose, Síndrome de Sjögren, mixoedema, bulimia; má nutrição (FULOP ${ }^{12}$, 1989; CAWSON; BINNIE; EVESON ${ }^{5}, 1995$; NEVILLE et al. ${ }^{18}$, 1995; TAGAWA et al. $\left.{ }^{29}, 1996\right)$; drogas (BOSCH et al. ${ }^{2}$, 1986; TAGAWA et al. ${ }^{29}$, 1996). Fatores locais como sialoadenites, sialolitíases, sialoses e lesão linfoepitelial benigna também podem ocasionálas (CAWSON; BINNIE; EVESON ${ }^{5}, 1995$; NEVILLE et al. $\left.{ }^{18}, 1995\right)$.

Alguns pacientes desdentados parciais ou totais podem apresentar tumefações não neoplásicas relacionadas às glândulas sublinguais que dificultam a adaptação de próteses, às vezes necessitando tratamento cirúrgico (CAMPOS ${ }^{3}$, 1996; DAMANTE et al. ${ }^{7}, 1999$; IWAKI FILHO ${ }^{13}$, 1999).

Poucos estudos vem sendo realizados com o objetivo de esclarecer a etiologia de tais tumefações. Na literatura, há quem as classifique como variações normais, resultantes apenas da reabsorção do rebordo alveolar (CASTRO ${ }^{4}$, 1995). Entretanto, já foram descritas como hiperplasia das glândulas sublinguais (CAMPOS $\left.{ }^{3}, 1996\right)$.

A observação clínica destas alterações somada à falta de informação sobre a conduta e o tratamento dos pacientes levou a um estudo clínico e microscópico in vivo (DAMANTE et al. ${ }^{7}, 1999$; IWAKI FILHO ${ }^{13}, 1999$ ). Atrofia acinar, aumento de estruturas ductiformes e substituição do parênquima por fibrose e tecido adiposo foram os principais aspectos microscópicos observados. A etiologia do quadro ficou a esclarecer, sendo o envelhecimento um dos possíveis fatores mencionados e discutidos. A ausência de estudos anteriores e, até mesmo, de padrões de normalidade da glândula sublingual humana, limitaram as conclusões.

Em 2003, um estudo morfológico descritivo em diferentes faixas etárias objetivando reconhecer as alterações histológicas ao longo dos anos 
foi realizado em glândulas sublinguais de cadáveres humanos. Foi estimado o envelhecimento glandular como um processo que se inicia pela atrofia de ácinos seguido do aumento do número de ductos e/ou estruturas ductiformes que resulta na substituição do parênquima por tecidos adiposo e/ou fibroso (AZEVEDO $\left.{ }^{1}, 2003\right)$.

O problema clínico das tumefações não neoplásicas do soalho bucal de desdentados não pôde ser explicado $\left(\right.$ CAMPOS $^{3}$, 1996; DAMANTE et al. $^{7}$, 1999; IWAKI FILHO ${ }^{13}$, 1999; AZEVEDO ${ }^{1}$, 2003). Permaneceu a dúvida se o processo de substituição redundaria no aumento do volume glandular. Este trabalho, envolvendo morfometria do parênquima e do estroma de glândulas sublinguais humanas em relação com a idade, é uma continuidade dos estudos acima referidos. Tem como objetivo quantificar as alterações morfológicas ao longo da vida e suas possíveis relações com os gêneros masculino e feminino. 
Revisão de Literatura 


\section{REVISÃO DA LITERATURA}

\subsection{Trabalhos específicos}

Em 1996, em estudo inédito, CAMPOS $^{3}$ descreveu tumefações assintomáticas do soalho bucal em alguns pacientes desdentados. Ele as considerou entidade patológica, denominando-as de "hiperplasia das glândulas sublinguais". Foram relatados 12 casos de pacientes de ambos os gêneros, entre 26 e 67 anos de idade. Os indivíduos apresentavam tumefações sublinguais uni ou bilaterais, assintomáticas, que protruíam do soalho da boca, eram macias à palpação e recobertas por mucosa normal. $\mathrm{O}$ tempo de evolução era desconhecido. Fatores locais foram descartados como possíveis causas. Todas as hiperplasias estavam associadas com perda total ou parcial de dentes posteriores inferiores. Desta forma, o autor sugeriu que a perda dos dentes teria contribuição no surgimento das hiperplasias, já que não conseguiu relacioná-las com nenhuma outra causa mais específica.

Em 1999, IWAKI FILHO ${ }^{13}$ analisou clinica e microscopicamente as tumefações do soalho de boca em desdentados parciais ou totais, propondo estabelecer a epidemiologia das tumefações do soalho, considerando idade cronológica, gênero, raça e lado de ocorrência. Foram obtidas vinte e quatro peças contendo glândulas sublinguais de dezenove pacientes (15 do gênero feminino e 4 do masculino, com idade variando de 48 a 74 anos) no período entre 1985 e 1999. O tratamento cirúrgico teve razões protéticas ou parafuncionais. Apesar do aspecto clínico alterado, seis glândulas foram consideradas histologicamente normais. Nas 18 glândulas restantes, entre outras, foram observadas as seguintes alterações: atrofia acinar, aumento no número de ductos e/ou estruturas ductiformes e, fibrose intersticial. As tumefações ocorreram principalmente em mulheres após a quarta década de vida, sempre associadas com ausência de dentes posteriores inferiores. $\mathrm{O}$ autor especulou sobre a etiologia, que julgou multifatorial com ênfase no processo de envelhecimento das glândulas sublinguais. Finalmente, pelas características clínicas e microscópicas das tumefações do soalho bucal em 
desdentados, o autor sugeriu que elas fossem reconhecidas como entidade nosológica.

Em 2003, AZEVEDO ${ }^{1}$ realizou um estudo microscópico morfológico descritivo ressaltando os efeitos do envelhecimento nas glândulas salivares sublinguais humanas, relacionando-os com o gênero e com a idade. Cento e oitenta e seis glândulas sublinguais humanas foram obtidas por meio de necropsias junto ao Serviço de Verificação de Óbitos da Capital, na Faculdade de Medicina da Universidade de São Paulo. Critérios de exclusão envolveram quaisquer condições patológicas em vida que pudessem influenciar a histologia glandular "post mortem" (SCOTT ${ }^{22}$, 1977a). Os indivíduos foram distribuídos em três grupos etários: I (0-30 anos); II (31-60 anos) e III (61-90 anos). O material foi analisado microscopicamente e os achados histológicos foram: 1) atrofia acinar, 2) ductos e/ou estruturas ductiformes, 3) infiltrado mononuclear, 4) substituição do parênquima por tecido fibroso e/ou adiposo, 5) oncocitose e 6) vasos sangüíneos congestos. O envelhecimento da glândula sublingual foi considerado marcante, tendo início com a atrofia acinar, seguido do aumento do número de ductos e/ou estruturas ductiformes, resultando na substituição do parênquima por tecidos adiposo e/ou fibroso. Outras observações incluíram a mudança do infiltrado mononuclear de focal para difuso e o aumento da oncocitose e de vasos sangüíneos congestos com a idade. Não houve diferenças estatisticamente significantes entre gêneros.

\subsection{Efeitos do envelhecimento nas glândulas salivares}

Alguns estudos têm objetivado esclarecer qualitativa e quantitativamente os efeitos do envelhecimento nas glândulas salivares. Porém, no que concerne ao estudo de glândulas salivares sublinguais humanas, a literatura é escassa e o conhecimento acumulado sobre as alterações das glândulas salivares com a idade decorre de alguns estudos post mortem em humanos e outros estudos em animais. Tais estudos envolveram, principalmente, parótidas, submandibulares, glândulas labiais e palatinas. 
Em 1973, WATERHOUSE et al. ${ }^{32}$ fizeram o primeiro estudo quantitativo avaliando a substituição do parênquima por tecido adiposo e tecido conjuntivo, em glândulas submandibulares humanas. Uma modificação do método morfométrico de contagem de pontos de CHALKLEY $^{6}$ (1943) para determinar o volume relativo de constituintes teciduais foi aplicada às glândulas submandibulares de 42 indivíduos (6 em cada década de vida entre 5 e 84 anos) de uma série de 211 necropsias, consecutivas. Uma redução gradual significativa do volume ocupado pelo parênquima glandular foi observada com a idade, devido a sua substituição por tecido conjuntivo e adiposo. Neste estudo, o maior volume ocupado pelo parênquima glandular foi de 76\%, (na faixa etária de 5-14 anos) e o menor, $30 \%$ (na faixa etária 75-84 anos). Houve perda de até 25\% do volume de células secretoras entre a infância e a velhice. Os resultados evidenciaram que a diminuição das células do parênquima estava relacionada com alterações do envelhecimento.

Em 1975, SCOTT ${ }^{21}$ estudou as diferenças entre o volume da glândula submandibular humana com relação à idade, gênero e lado. Cento e cinqüenta e três glândulas submandibulares foram obtidas por necropsias de indivíduos entre 16 e 95 anos e os seus volumes avaliados por deslocamento de líquido de baixa densidade. O autor relatou grande variação do volume glandular, não só entre indivíduos como também entre os lados direito e esquerdo. Houve diferença estatisticamente significante entre os gêneros, sendo as glândulas masculinas mais volumosas. Em mulheres idosas, foi observada diminuição estatisticamente significante do volume glandular.

Em 1977a, SCOTT ${ }^{22}$ realizou um estudo histológico quantitativo sobre as mudanças causadas pelo envelhecimento em glândulas submandibulares humanas. Uma glândula submandibular de cada uma das 96 necropsias foi utilizada e o total foi distribuído por gênero e idade entre 16-95 anos, em 3 grupos: 16-35 anos (jovem), 36-75 anos (meia-idade) e 76-95 anos (idoso). As seguintes condições clínicas constituíram-se em critérios de exclusão da amostra: obesidade, caquexia, história recente de administração de drogas 
citotóxicas ou radioterapia à região de cabeça e pescoço, diagnóstico de leucemia, linfoma, doenças do colágeno, Síndrome de Sjögren, mucoviscidose, diabete melito, cirrose hepática e autólise severa. O autor observou que, durante oito décadas, os ácinos perderam em média 40\% de volume em relação ao grupo jovem. Em contrapartida, o volume de ductos sofreu um crescimento gradual em torno de 30\% com o aumento da idade. Houve substituição contínua do parênquima por tecido fibroso e tecido adiposo e o aumento de volume dos vasos foi relacionado com o aumento da prevalência de doenças vasculares degenerativas que acompanham o envelhecimento.

Em 1980, SCOTT $^{24}$ realizou um estudo histológico qualitativo e quantitativo em glândulas salivares labiais humanas. Os espécimes, obtidos em 70 necropsias, foram distribuídos em 3 grupos etários: 18-40 anos, 41-65 anos e 66-90 anos. Os critérios de exclusão da amostra e o processamento do material obtido foram os mesmos de trabalhos anteriores (SCOTT ${ }^{22}$, 1977a; SCOTT ${ }^{23}$, 1977b). A análise morfométrica da densidade de volume de ácinos, ductos, tecido adiposo e outros tecidos foi realizada com objetiva de 100X e retículo com 25 pontos. Houve grande variação na histologia dos diferentes espécimes. Os efeitos do envelhecimento em glândulas labiais foram semelhantes àqueles encontrados em glândulas submandibulares. Assim, atrofia acinar, dilatação ductal, hiperplasia ductal e fibrose aumentaram com a idade. Ocorreu uma redução progressiva na proporção de volume glandular ocupada pelos ácinos, com correspondente aumento na proporção de ductos e tecido fibroso. Não foi observada diferença estatisticamente significante entre os gêneros.

Em 1984, DRUMMOND; CHISHOLM ${ }^{11}$ fizeram um estudo qualitativo e quantitativo do envelhecimento nas glândulas salivares labiais. Trinta e seis glândulas labiais de cadáveres entre 25 e 80 anos, de ambos os gêneros, foram analizadas microscopicamente. Ácinos, ductos, tecido conjuntivo, tecido vascular e outros tecidos foram os componentes quantificados, sendo utilizado o total de 2000 pontos por glândula. Houve 
diminuição na densidade de volume de ácinos, e aumento na densidade de volume dos ductos e do tecido conjuntivo.

Em 1986, SCOTT; BODNER; BAUM ${ }^{26}$ estudaram os efeitos do envelhecimento em glândulas submandibulares e sublinguais de ratos. Dois grupos de 12 ratos machos, com idades de 6 e 24 meses foram sacrificados, e tiveram uma glândula submandibular removida e separada da glândula sublingual. O método estereológico adotado foi o da volumetria relativa de contagem de pontos à semelhança de estudos anteriores com humanos $\left(\right.$ SCOTT $\left.^{22}, 1977 \mathrm{a}\right)$. Um ponto por campo, em um total de 800 campos para glândula submandibular e 700 campos para glândula sublingual, foi contado sobre ácinos, ductos (intercalares, estriados e excretores) e tecido vascular ou conjuntivo. Na glândula submandibular também foram avaliados os ductos granulosos. Houve diminuição na densidade de volume dos ácinos, aumento dos ductos e do tecido conjuntivo nas submandibulares. Não houve alterações volumétricas nas estruturas das sublinguais. Os autores sustentaram que o envelhecimento biológico não ocorre de forma simultânea em todas as glândulas salivares.

No mesmo ano, SASHIMA ${ }^{20}$ realizou um estudo morfométrico e ultraestrutural dos efeitos do envelhecimento em glândulas submandibulares de rato. Para o estudo morfométrico, grupos de quatro ratos foram divididos por idade: 2, 4, 6, 12 e 22 meses. As duas glândulas submandibulares de cada animal foram removidas, pesadas, fixadas, incluídas em parafina e cortadas com $4 \mu \mathrm{m}$. Dois cortes de cada glândula foram examinadas morfometricamente pelo método de contagem de pontos num aumento de 100X. A análise morfométrica revelou que os ductos se desenvolviam entre 2 e 6 meses, alcançando o pico nos 6 meses. Dos 6 aos 22 meses estes ductos pareciam diminuir gradualmente. Não houve diferenças estatisticamente significantes entre os grupos no volume relativo dos ácinos, apesar deste ter sido maior em ratos adultos jovens (2 e 4 meses).

Também em 1986, KOMESU et al. ${ }^{14}$ estudaram as alterações morfológicas resultantes do envelhecimento nas glândulas submandibulares de ratos. Foram utilizados 40 ratos machos divididos igualmente em 4 
grupos etários de 3, 6, 12 e 24 meses. As glândulas foram processadas, cortadas com $7 \mu \mathrm{m}$ e coradas em hematoxilina-eosina. Diminuição do parênquima, aumento aparente de ductos e atrofia acinar foram eventos relatados. Os autores concluíram que o envelhecimento parecia provocar a atrofia do parênquima por meio de isquemia vascular, resultando no aumento da fibrose estromal. A alteração nos níveis dos hormônios responsáveis pela manutenção estrutural e funcional das glândulas salivares também estaria relacionada ao envelhecimento.

Ainda em 1986, DE WILDE et al. ${ }^{10}$ realizaram um estudo morfométrico das alterações histológicas com o envelhecimento em glândulas labiais humanas. Sessenta e oito indivíduos voluntários foram divididos em 7 grupos etários, de 10 a 79 anos. Os componentes glandulares quantificados foram ácinos, tecido fibroso, ductos intralobulares, vasos, foco linfocítico (acima de 50 linfócitos ou histiócitos), foco escore (número de focos linfocíticos por $4 \mathrm{~mm}^{2}$ de tecido) e infiltrado linfoplasmocitário difuso. A análise morfométrica foi realizada no computador e em microscópio óptico com diferentes objetivas e retículos. Atrofia acinar, fibrose, hiperplasia e dilatação ductal foram achados comuns com a idade.

MINTZ; MOORADIAN ${ }^{17}$, em 1987, removeram as glândulas sublinguais de ratos Fisher 344 com 3,5; 12; 18 e 24 meses de idade. A análise morfométrica foi realizada no aumento de 200X com retículo de 42 pontos, sendo, no mínimo, 2000 pontos contados por glândula. Ácinos, tecido conjuntivo intralobular, tecido conjuntivo extralobular, vasos sangüíneos, ductos excretores, estriados e intercalares foram os componentes aferidos. As densidades de volume acinar, de tecido conjuntivo e vascular permaneceram estáveis com a idade. A fração de volume ocupada pelos ductos aumentou, o mesmo ocorrendo com o aparecimento de metaplasia escamosa do epitélio ductal, focos de infiltrado linfocítico periductais e infiltração linfocítica periductal difusa.

KOMESU et al. ${ }^{15}$, em 1987, continuando o estudo anterior, realizaram um estudo morfométrico dos ácinos das glândulas submandibulares de ratos empregando a técnica morfométrica de CHALKLEY ${ }^{6}$ (1943). Cinco pontos- 
padrões e uma objetiva de 100X foram utilizados na contagem de 500 pontos por glândula. Ocorreu a diminuição do parênquima associada ao aumento de componentes estromais com a idade. Oncócitos, atrofia acinar, diminuição de volume e polimorfismo nuclear foram eventos observados.

Em 1987, SCOTT; FLOWER; BURNS ${ }^{27}$ realizaram um estudo quantitativo das alterações histológicas do envelhecimento em glândulas parótidas. Lóbulos superficiais de glândulas parótidas de 63 necropsias de indivíduos de ambos os gêneros foram distribuídos em 4 grupos etários de 17 a 90 anos. A análise estereológica dos componentes teciduais da glândula parótida foi realizada através do mesmo método utilizado em trabalho anteriormente citado (SCOTT ${ }^{22}$, 1977a). O estudo quantitativo encontrou uma redução de aproximadamente $32 \%$ do tecido acinar entre a idade adulta e a velhice. Esta perda se aproximou da obtida em estudos anteriores em glândulas submandibulares (37\%) (SCOTT $\left.{ }^{22}, 1977 a\right)$, mas era um tanto menor do que a obtida em glândulas labiais (45\%) (SCOTT ${ }^{24}$, 1980). O volume proporcional do componente ductal permaneceu estável nos quatro grupos etários. As médias dos tecidos vascular e adiposo variaram de 4,7 a $6,1 \%$ e de 18,9 a $27,2 \%$, respectivamente, do grupo mais jovem ao mais velho. Os autores observaram que as alterações do envelhecimento se assemelhavam àquelas encontradas nas outras glândulas salivares, mas ao contrário do que ocorria com estas, tais alterações não pareciam ser acompanhadas por deteriorações funcionais, sugerindo maior capacidade secretora dos ácinos ou maior reserva de secreção na parótida em relação às outras glândulas.

Em 1989, KOMESU et al. ${ }^{16}$ também em seqüência ao estudo das alterações morfológicas resultantes do envelhecimento na glândula submandibular de rato (KOMESU et al. ${ }^{14}, 1986$ ), apresentaram um estudo morfométrico dos ductos. A técnica morfométrica de CHALKLEY ${ }^{6}$ (1943), com a mesma metodologia do estudo anterior (KOMESU et al. ${ }^{15}$, 1987), foi empregada. Aumento aparente na proporção dos ductos e núcleos com menor volume ou polimórficos, foram observados. Ocorreu diminuição na altura das células dos ductos granulosos nos animais de idade avançada. 
Em 2000, VERED et al. ${ }^{31}$ realizaram um estudo histomorfométrico das alterações do envelhecimento em glândulas salivares labiais humanas em 120 glândulas obtidas através de necropsias. As amostras foram divididas em jovens (menores de 30 anos), adultos (30 a 60 anos) e idosos (maiores de 60 anos). O método estereológico foi baseado na contagem de pontos com aumento de 250X e retículo de $1,5 \times 1,5 \mathrm{~cm}^{2}$. Ácinos, ductos, tecido conjuntivo, vasos sangüíneos e linfáticos, infiltrado inflamatório e tecido adiposo foram os componentes quantificados. Foi observada notória diminuição na densidade de volume das células acinosas seromucosas (em torno de 49,3\%) acompanhada por uma menor diminuição na densidade de volume das células acinosas mucosas (28,5\%). De acordo com os autores, este fato pôde explicar a diminuição na secreção das glândulas salivares labiais com a idade. Alterações nos ductos não foram estatisticamente significantes. Dos componentes do estroma, a densidade de volume de tecido adiposo foi o que mostrou maior crescimento, seguido pelo infiltrado inflamatório.

Também em 2000, DAYAN et al. ${ }^{9}$ estudaram histomorfometricamente o envelhecimento em glândulas palatinas humanas com a mesma metodologia utilizada no trabalho acima citado. Houve diminuição na densidade de volume acinar e aumento na de ductos e de componentes estromais. Os autores concluíram que essas alterações na histologia glandular podem estar relacionadas com as mudanças funcionais decorrentes do envelhecimento.

Como pode ser percebido, não é rica em números a literatura relacionada às transformações das glândulas salivares com a idade. Em seres humanos, os estudos são poucos e a glândula sublingual quase não é contemplada. A despeito das diferenças nas metodologias utilizadas nas investigações, percebe-se, de forma geral, que o componente acinar tende a diminuir com a idade, havendo uma substituição por tecido fibroso e/ou adiposo. 
Proposição 


\section{PROPOSIÇÃo}

Devido à inexistência de trabalhos direcionados a quantificar as alterações histológicas na glândula sublingual humana com a idade, propomo-nos a determinar:

1. A densidade de volume de ácinos, ductos, estroma, tecido adiposo e septos;

2. O volume absoluto da glândula e de cada componente glandular avaliado;

3. A relação parênquima/estroma e ácinos/ductos;

4. Relacionar os dados obtidos, com a idade cronológica e o gênero.

A partir destes dados, pretendemos caracterizar quantitativamente as modificações histológicas que ocorrem na glândula sublingual durante o envelhecimento. 
Material e Métodos 


\section{MATERIAL E MÉTODOS}

\subsection{Material}

\subsubsection{Obtenção das glândulas sublinguais humanas}

De 294 glândulas sublinguais humanas, removidas de 147 cadáveres do Serviço de Verificação de Óbitos da Capital (SVOC)* 90 glândulas do lado direito foram utilizadas no presente estudo. Elas foram agrupadas segundo o gênero e a idade cronológica dos indivíduos (Tabela 1). As idades variaram de 7 meses a 92 anos.

Para a seleção dos 90 indivíduos foram excluídos dos 147 da amostra global aqueles casos onde a causa do óbito ou a doença de base envolvesse: linfoma, leucemia, mucoviscidose, doenças reumáticas, Síndrome de Sjögren, obesidade, caquexia, diabete melito, cirrose alcoólica e doenças do colágeno. Também foram fatores de exclusão: história de radioterapia de cabeça e pescoço, uso de terapia esteróide ou citotóxica nos 3 últimos meses de vida, autólise macroscópica e padrões histológicos de autólise incompatíveis com a delimitação dos ácinos.

Pertence à Faculdade de Medicina da Universidade de São Paulo - USP. Cadáveres de mortes naturais são encaminhados ao
serviço por hospitais da capital, (estado de São Paulo - Brasil) conveniados com o SUS. As famílias assinam um termo de serviço por hospitais da capital, (estado de São Paulo
consentimento padrão autorizando projetos desta natureza. 
TABELA 1 - Distribuição dos indivíduos da amostra segundo a idade e o gênero

\begin{tabular}{c|c|c|c}
\hline \multirow{2}{*}{ Idade em anos } & \multicolumn{2}{|c|}{ Gênero } & \multirow{2}{*}{ Total } \\
\cline { 2 - 3 } & Masculino & Feminino & \\
\cline { 2 - 3 } 0 & $\mathrm{~N}$ & $\mathrm{~N}$ & 9 \\
$11-20$ & 5 & 4 & 6 \\
$21-30$ & 4 & 5 & 10 \\
$31-40$ & 5 & 6 & 10 \\
$41-50$ & 5 & 4 & 9 \\
$51-60$ & 6 & 5 & 11 \\
$61-70$ & 7 & 6 & 13 \\
$71-80$ & 7 & 5 & 12 \\
$81-92$ & 5 & 5 & 10 \\
\hline
\end{tabular}




\subsection{Métodos}

\subsubsection{Procedimentos histológicos}

O processamento do material foi realizado no laboratório de Histologia da Faculdade de Odontologia de Bauru - USP. A massa glandular foi determinada, após a fixação da peça, em uma balança de precisão Mettler Toledo AT261 Delta Rang com sensibilidade de 0,01mg. Na macroscopia, cada glândula foi seccionada em fatias de $5 \mathrm{~mm}$ de espessura, independente do tamanho. As porções anterior e posterior da glândula foram desprezadas. Apenas três fatias estratificadas a intervalos regulares foram processadas, independentemente do tamanho da glândula (Figura 1).

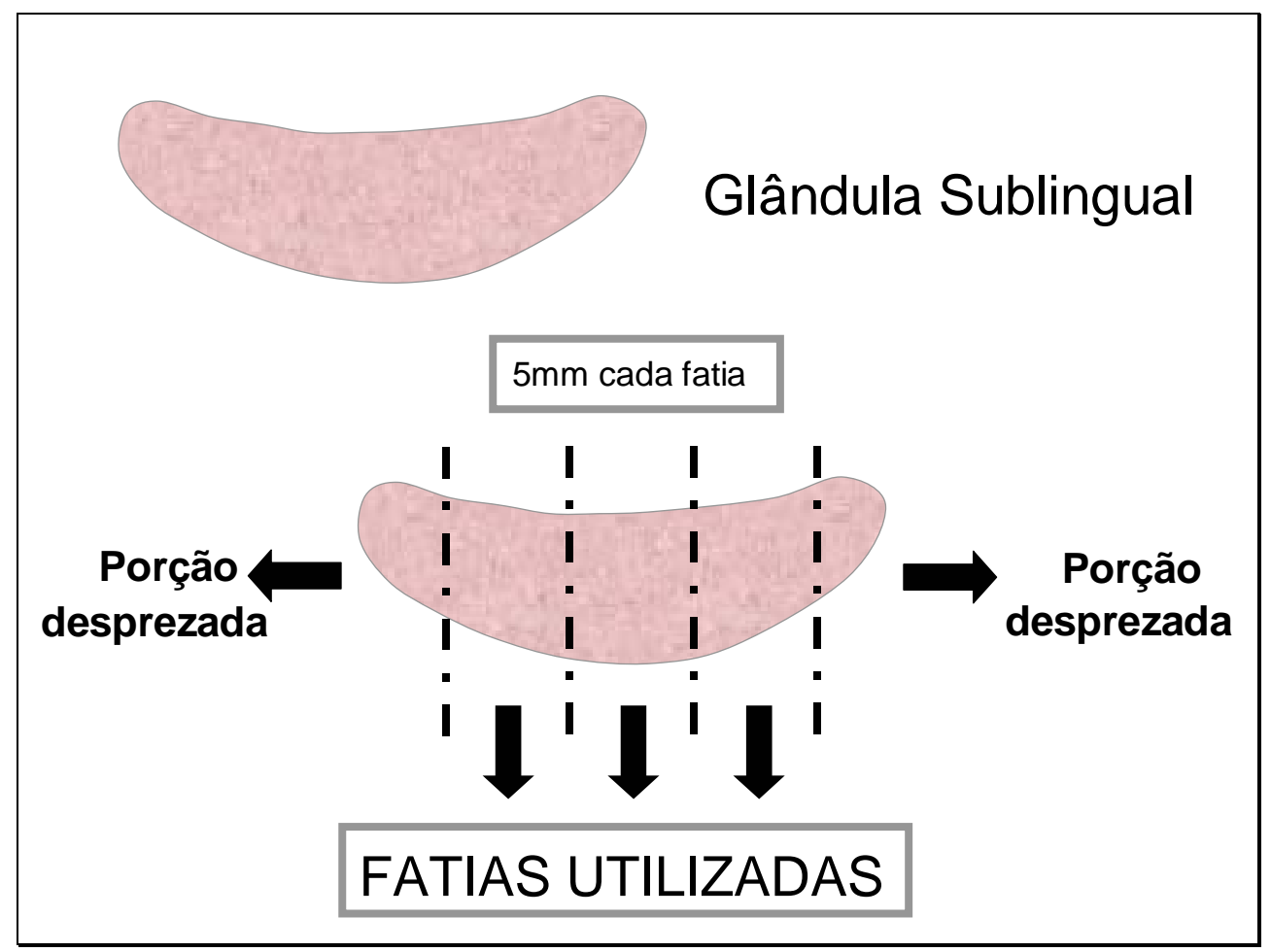

FIGURA 1 - Esquema mostrando as secções transversais da glândula sublingual durante a macroscopia

As fatias de cada glândula foram lavadas em água corrente durante 24 horas e, em seguida, mantidas em álcool 70\% por mais 24 horas. No dia subseqüente, o material foi submetido a procedimentos estandardizados de desidratação em álcool etílico, clarificação em xilol e embebição em Histosec - Merck (parafina + resina plástica). Cortes alternados de $5 \mu \mathrm{m}$ de 
espessura de cada fatia glandular foram obtidos em micrótomo Jung-Leitz Multicut e corados pela técnica da hematoxilina - eosina (H.E.).

\subsubsection{Análise morfométrica*}

\subsubsection{Avaliação da densidade da glândula sublingual}

A densidade (d) da glândula sublingual humana foi calculada a partir de sete glândulas em uma balança Mettler Toledo AT261 Delta Rang, contendo conjunto de acessórios Mettler AT/AG e PG/PG-S/PR. A determinação da densidade glandular foi baseada no Princípio de Archimedes, onde a densidade de um corpo $(\mathrm{d})=(\mathrm{m} / \mathrm{v})$. $\mathrm{d}_{\text {água }}$; onde: $\mathrm{m}=$ massa da glândula, $v$ = volume de água deslocado, e dágua =densidade da água a temperatura de $21^{\circ} \mathrm{C}$.

Para todas as idades foi utilizada a mesma densidade, igual a $1,03 \mathrm{~g} / \mathrm{cm}^{3}$, correspondente a média aritmética das densidades das sete glândulas utilizadas.

4.2.2.2 Determinação da retração provocada pelo processamento histológico

A retração provocada pelo processamento histológico foi determinada a partir de sete glândulas sublinguais previamente fixadas em formol a 10\%. As glândulas foram cortadas em fatias e uma fatia de cada foi lavada em água por 24 horas.

As fatias das glândulas foram colocadas sobre um papel de filtro, posicionadas sobre uma placa de cera rosa $\mathrm{n}^{\circ}$ 7, e levadas até o congelador por 10 minutos. Após um leve enrijecimento dos tecidos, foram recortadas com uma lâmina de barbear nova, dando um perfil retangular. Cada fragmento foi levado a um estereomicroscópio Bausch \& Lomb, com lente objetiva 0,63x e ocular micrométrica Olympus de 10x, tipo Ramsden, com filamento deslocável. As dimensões do comprimento e largura foram obtidas e convertidas para $\mu \mathrm{m}$.

\footnotetext{
* O Estudo morfométrico foi orientado pelo Prof. Dr. Rumio Taga, do Departamento de Ciências Biológicas da FOB-USP, com experiência comprovada em vasta linha de investigação em animais. As medições foram realizadas pela candidata.
} 
Em seguida, cada fragmento recebeu os procedimentos histológicos padronizados, chegando até a inclusão em parafina. Nesta fase, o fragmento em bloco foi levado novamente até o estereomicroscópico onde foram determinadas as novas dimensões da superfície.

Foi calculada a média aritmética dos valores obtidos antes e após o processamento para achar um lado médio, ou seja, transformar um retângulo em um quadrado. Esse valor foi elevado à terceira potência e o volume do fragmento da glândula foi obtido inicialmente (Si) e após o processamento até bloco (Sp), já que é considerada desprezível a retração do material entre a fase de bloco e a coloração.

O fator de retração $(\mathrm{Fr})$ foi estimado a partir da relação: $\mathrm{Fr}=\mathrm{Sp}^{3} / \mathrm{Si}^{3}$ para cada fragmento. Para todas as idades foi utilizado o mesmo valor do fator de retração, igual a 0,878, correspondente a média aritmética de todos os fatores de retração obtidos.

\subsubsection{Estimativa do volume glandular processado}

Para a determinação do volume total de cada componente glandular (Vt) é necessário conhecer o volume do órgão após todas as fases do processamento histológico.

O volume glandular processado (Vglandular) foi calculado através da massa (m) da glândula, da densidade (d) do órgão e do percentual de retração provocado pelo processamento histológico (Fr), pela seguinte relação:

$$
\text { Vglandular }=\mathrm{m} / \mathrm{d} . \mathrm{Fr}
$$

\subsubsection{Sistema-teste utilizado nas avaliações morfométricas}

Para avaliação da densidade de volume (Vvi) de cada componente glandular (i) foi utilizado um microscópio Olympus com objetiva de 40x e ocular Kpl 8x Zeiss contendo um retículo de integração II Zeiss, constituído por 10 linhas paralelas e 100 pontos simetricamente distribuídos dentro de uma área quadrada (Figura 2).

Com a objetiva de 40x as dimensões do sistema-teste valem: 

a) cada lado do quadrado $=335 \mu \mathrm{m}$;
b) área do sistema-teste: $112.225 \mu \mathrm{m}^{2}$;
c) comprimento de cada linha $=305 \mu \mathrm{m}$;
d) comprimento total das linhas $=3050 \mu \mathrm{m}$;
e) distância entre as linhas = 30 $\mu \mathrm{m}$;
f) número de pontos de cada linha = 10;
g) número total de pontos $=100$.

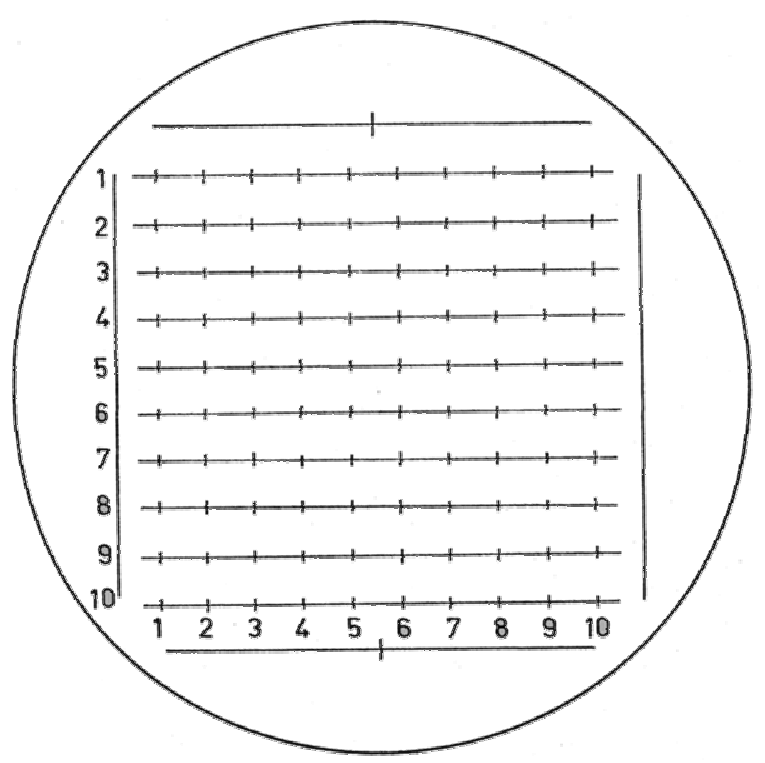

FIGURA 2 - Retículo de integração II Zeiss

\subsubsection{Casualização dos campos microscópicos}

De cada fatia foram obtidas 1 ou 2 lâminas histológicas contendo 3 cortes alternados. De cada glândula, três cortes foram selecionados para a quantificação por amostragem sistemática (WEIBEL $\left.{ }^{33}, 1969\right)$. Os 51 campos histológicos selecionados por glândula foram igualmente divididos e distribuídos entre os três cortes.

Na amostragem sistemática, os campos histológicos são escolhidos a intervalos regulares em cada corte histológico, de tal maneira a ter uma amostra representativa de toda área do corte (TAGA; SESSO; PARDINI ${ }^{28}$, 1998). Como as glândulas variavam muito de tamanho entre si, foi 
necessária, primeiramente, a realização de um mapeamento dos cortes selecionados para a determinação do número total de campos por glândula.

Na casualização sistemática o sistema-teste é colocado sobre o corte histológico em intervalos regulares, selecionando os campos histológicos para as quantificações (Figura 3).

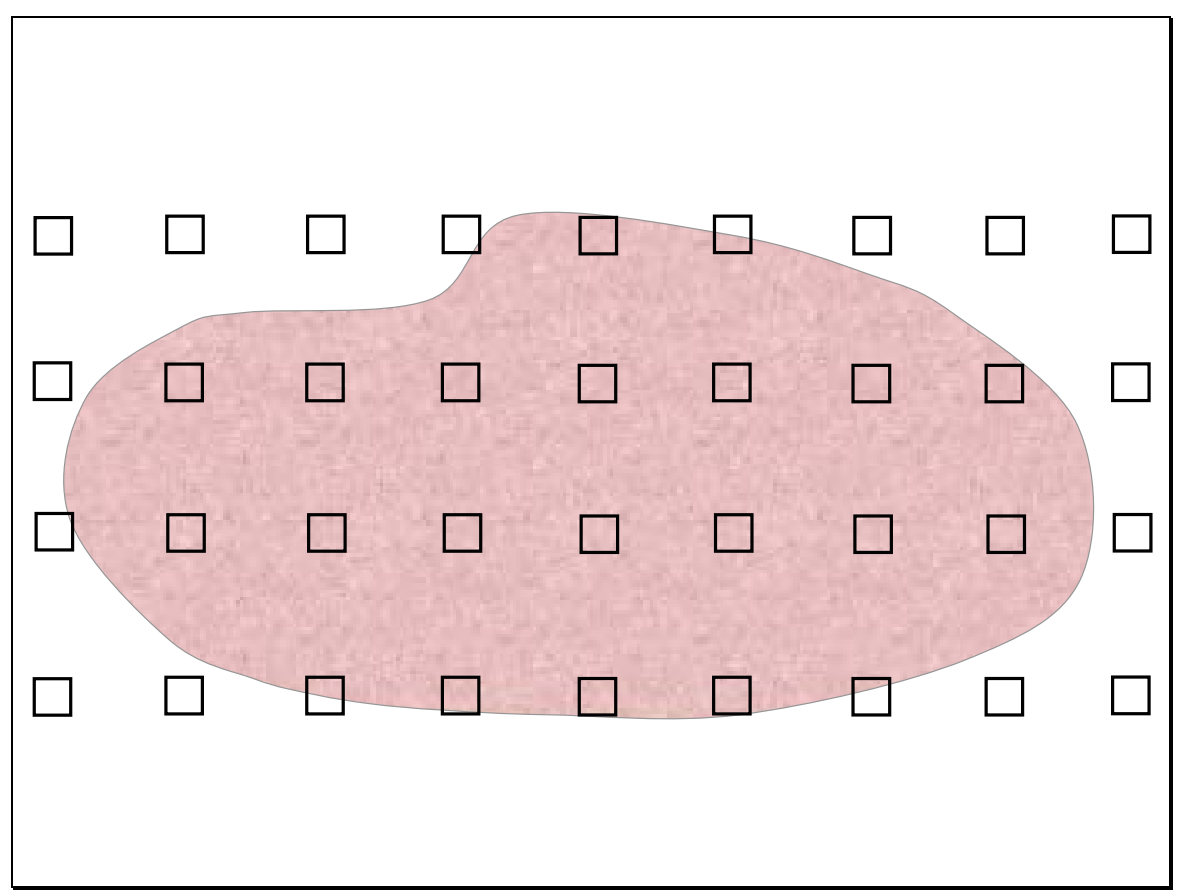

FIGURA 3 - Esquema de casualização sistemática que representa um corte de glândula sublingual. Os quadrados preenchidos representam os campos a serem contados

4.2.2.6 Determinação da densidade de volume (Vvi) de cada componente glandular

A densidade de volume (Vvi) ou fração de volume glandular ocupada por uma determinada estrutura (i) foi avaliada pela técnica de volumetria relativa de contagem de pontos (WEIBEL $\left.{ }^{33}, 1969\right)$.

Este método é baseado em princípios básicos onde a fração de volume ocupada por uma estrutura (i) é proporcional à fração de área ocupada por perfis do mesmo objeto, sendo: Vvi = AAi. A fração de área pode ser determinada colocando-se sobre a amostra um retículo de pontos 
arranjados regularmente e contando o número de pontos que caiam sobre a estrutura interessada, ou seja: AAi = PPi.

Assim, a densidade de volume foi determinada com a utilização do

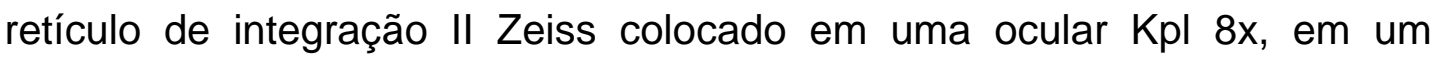
microscópio Olympus com uma objetiva de 40x. Nos campos histológicos casualizados por espécime, foram anotados o número de pontos sobre uma estrutura glandular em estudo $(\mathrm{Pi})$ e o número total de pontos sobre a glândula (Pt) (Figura 4). A densidade de volume de cada componente glandular foi calculada pela seguinte relação:

$$
\mathrm{Vvi}=\mathrm{Pi} / \mathrm{Pt}
$$

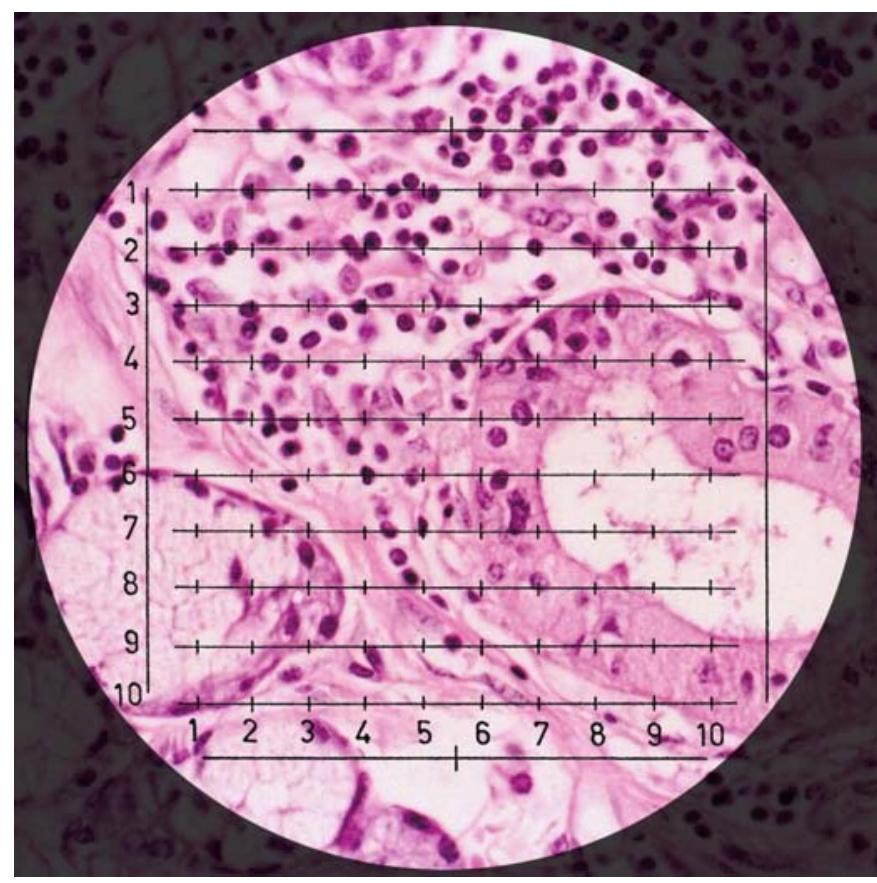

FIGURA 4 - Determinação da densidade de volume de cada estrutura pela contagem de pontos. Esquema ilustrativo

A densidade de volume ( $\mathrm{Vvi}$ ) é expressa como porcentagem ou como uma fração de 1.

As médias dos grupos etários para cada compartimento foram confrontadas entre si para calcular a redução ou aumento dos eventos aferidos (SCOTT ${ }^{25}, 1986$ ). 
4 2.2.7 Determinação do coeficiente de variação da média

O coeficiente de variação da média ("erro") associado à avaliação da densidade de volume (Vvi) foi determinado pela aplicação da relação:

$$
e=\sqrt{\frac{1-P p i}{\text { Pt.Ppi }}}
$$

onde,

e = "erro" (coeficiente da variação da média da proporção);

Ppi = fração de volume ocupada pela estrutura na glândula;

$\mathrm{Pt}=$ número total de pontos sobre a glândula $\left(\mathrm{PARDINI}^{19}, 1985\right)$.

4.2.2.8 Determinação do volume absoluto de cada estrutura

Conhecendo-se o volume glandular processado (Vglandular), o volume de cada componente $(\mathrm{Vt})$ foi calculado pela fórmula:

$$
\mathrm{Vt}=\mathrm{V} v \mathrm{x} \text { V Vglandular }
$$

Desta forma, obtivemos o volume absoluto de cada estrutura da glândula em $\mathrm{cm}^{3}$. A partir destes valores, determinamos as relações: parênquima (ácinos + ductos)/estroma e ácinos/ductos.

\subsubsection{Critérios adotados nas quantificações}

A análise morfométrica foi realizada de acordo com os seguintes critérios:

a) ácinos: a contagem englobou os ácinos mucosos (Figura 5), serosos e mistos em uma só variável;

b) ductos: não houve distinção entre os intra e interlobulares (Figura 6). As estruturas semelhantes aos ductos ou ductiformes (Figura 7) foram enquadradas neste item. Quando da existência de qualquer vestígio de célula acinar, eram contadas como ácinos, ainda que atróficos;

c) estroma: incluiu tecido conjuntivo (Figuras 7 e 14), células e vasos sangüíneos (Figura 8) e infiltrado inflamatório (Figura 9);

d) mucosa: grande parte dos cortes trazia uma faixa de mucosa bucal como referência (Figura 10). Estes campos foram quantificados separadamente para posterior exclusão do peso glandular. Em alguns casos, observou-se 
parte da glândula submandibular (Figura 11) que também foi contada como mucosa com o mesmo objetivo;

e) artefatos: os pontos que caíam no vazio (Figura 12);

f) tecido adiposo: o tecido adiposo (Figura 13) foi quantificado separadamente em virtude da substituição do parênquima por gordura (Figura 14) ser um achado freqüente;

g) septos: septos intralobulares, interlobulares (Figura 15) e a cápsula da glândula (Figura 16) estão agrupados neste item;

h) autólise acinar: o fenômeno se repetiu em diferentes faixas etárias apagando-se os limites entre as células, mas mantendo-se o contorno do ácino. Assim, o ácino com autólise (Figura 17) foi contado como "ácino" para que o verdadeiro volume ocupado pelos ácinos fosse aferido.

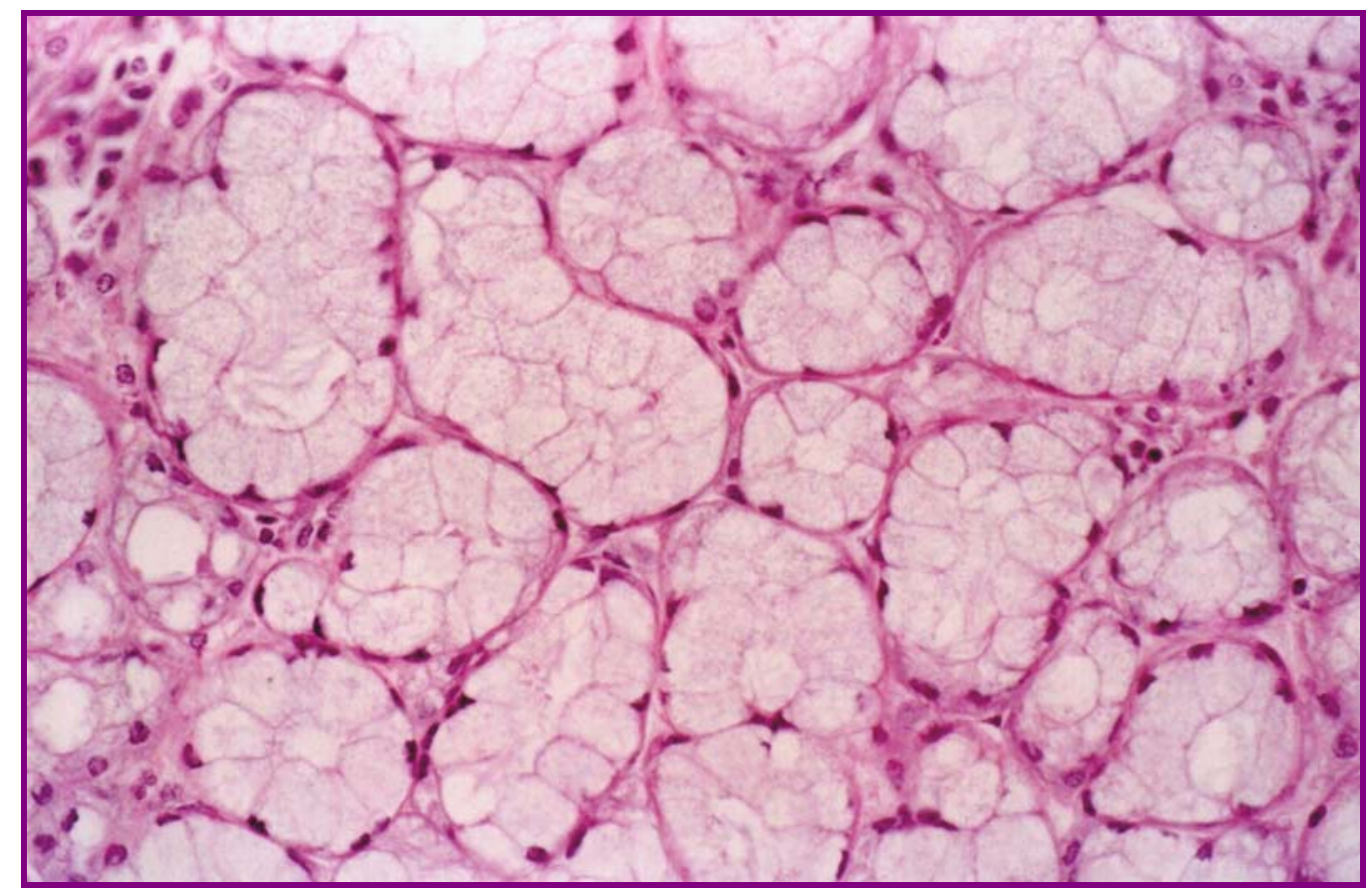

FIGURA 5 - Ácinos mucosos da glândula sublingual. Mulher de 47 anos. (H.E.; aumento 550X) 


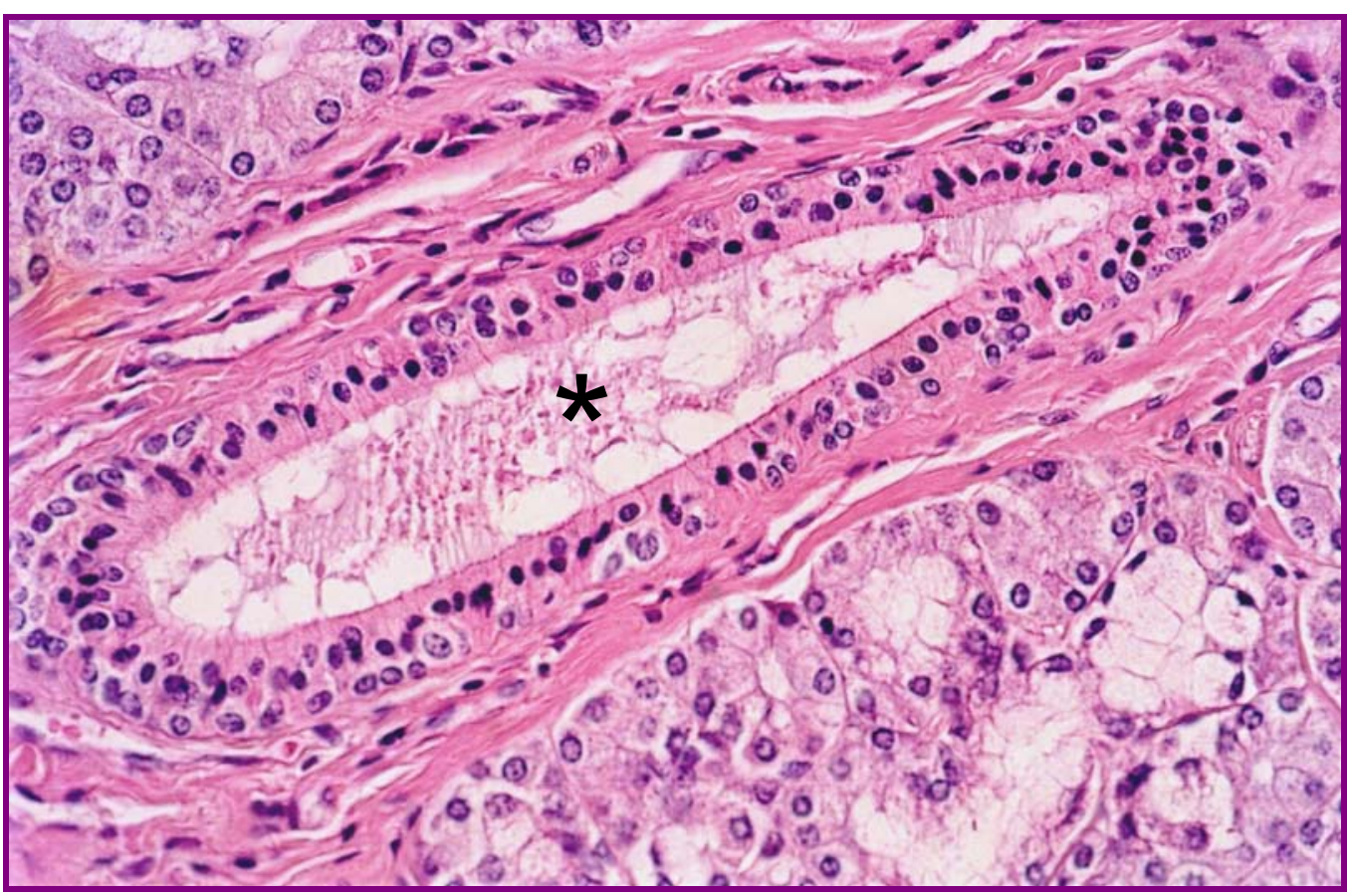

FIGURA 6 - Ducto excretor interlobular $\left(^{*}\right)$ da glândula sublingual. Mulher de 39 anos. (H.E.; aumento 550X)

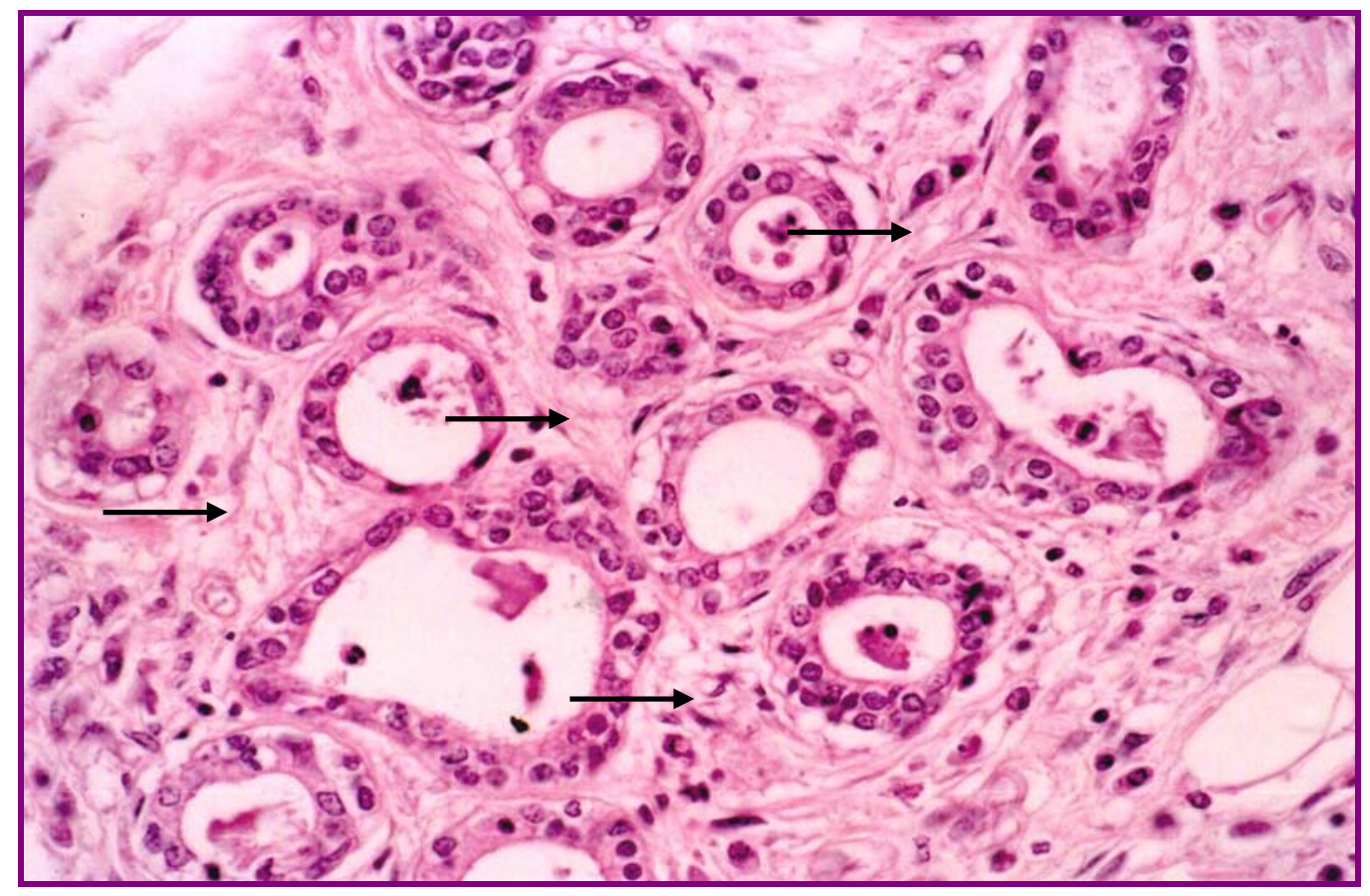

FIGURA 7 - Estruturas ductiformes e tecido conjuntivo (setas) em sublingual atrófica. Homem de 70 anos. (H.E.; aumento 550X) 


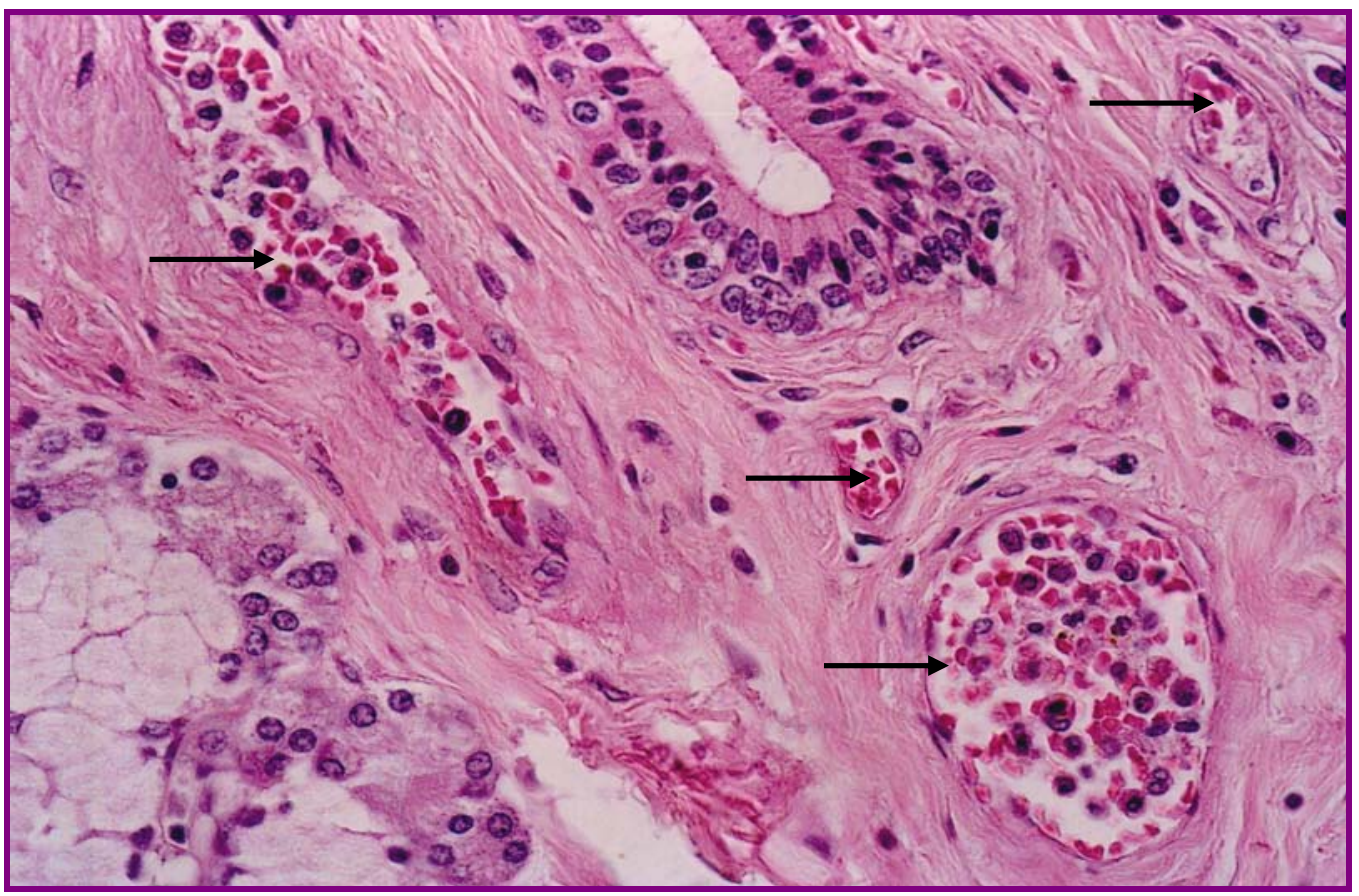

FIGURA 8 - Células do sangue e vasos (setas) em glândula sublingual. Mulher de 39 anos. (H.E.; aumento 550X)

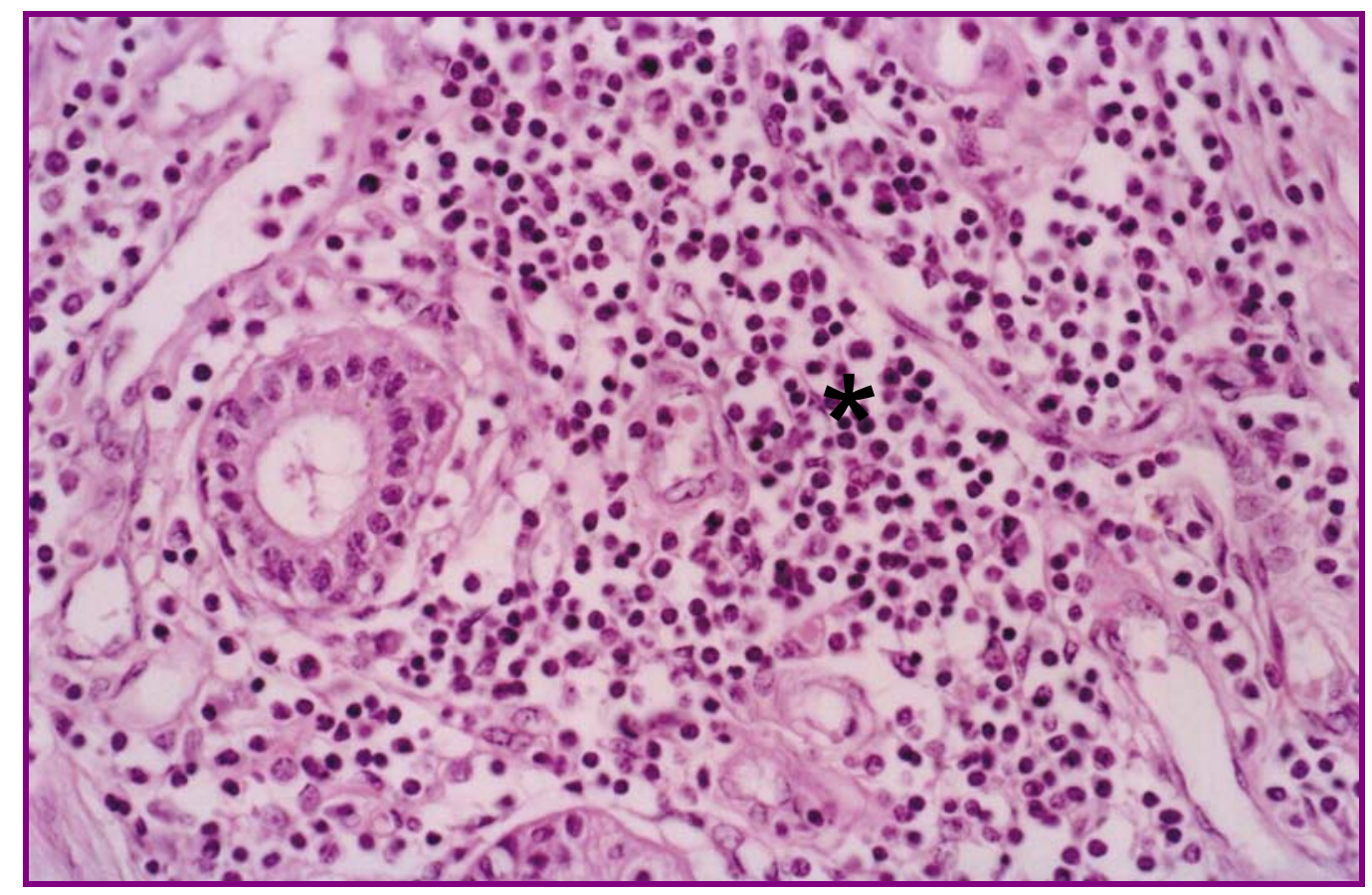

FIGURA 9 - Infiltrado inflamatório (*) em glândula sublingual. Mulher de 73 anos. (H.E.; aumento 550X) 


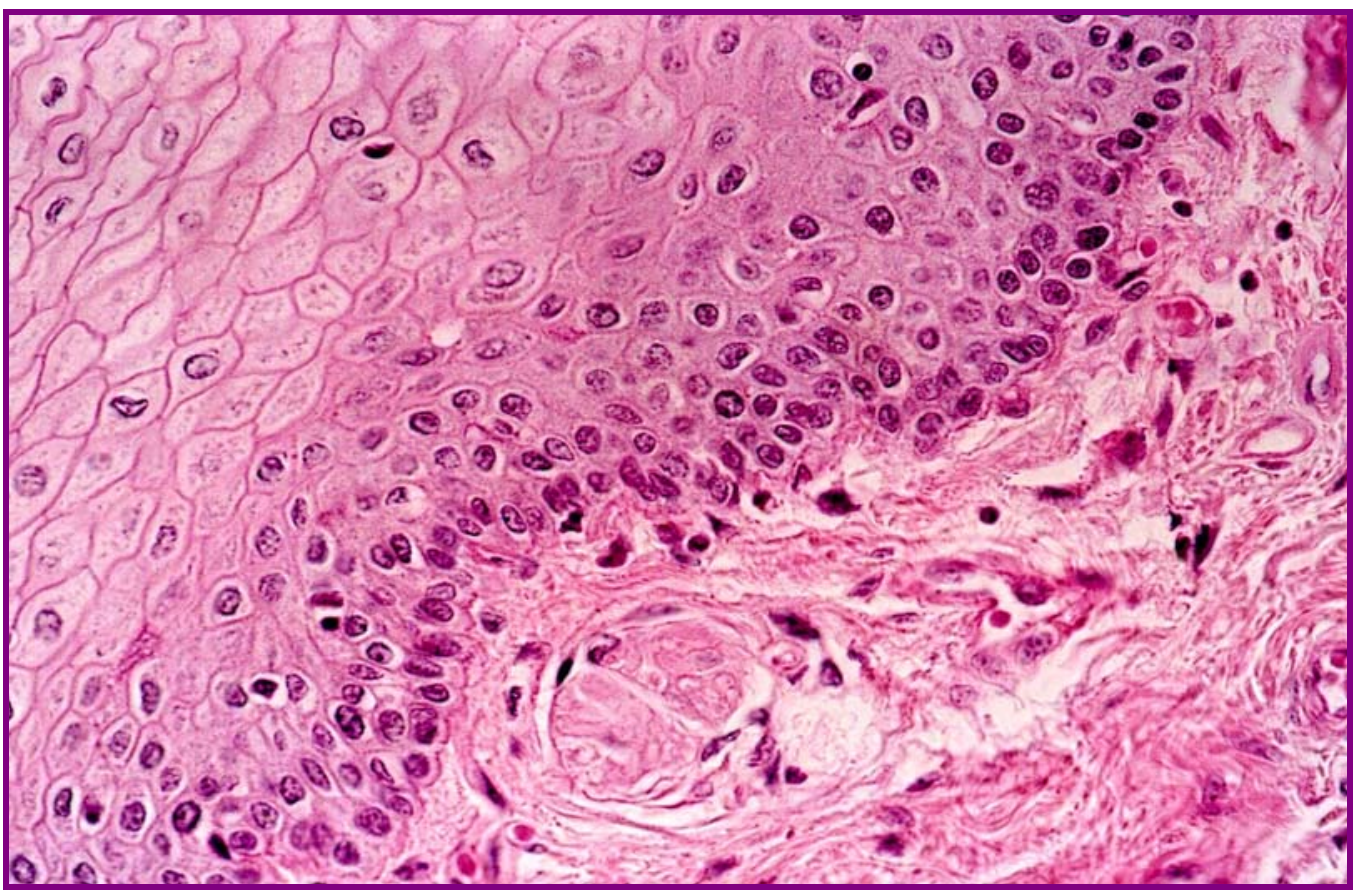

FIGURA 10 - Epitélio do soalho bucal e tecido conjuntivo subjacente. Mulher de 59 anos. (H.E.; aumento 550X)

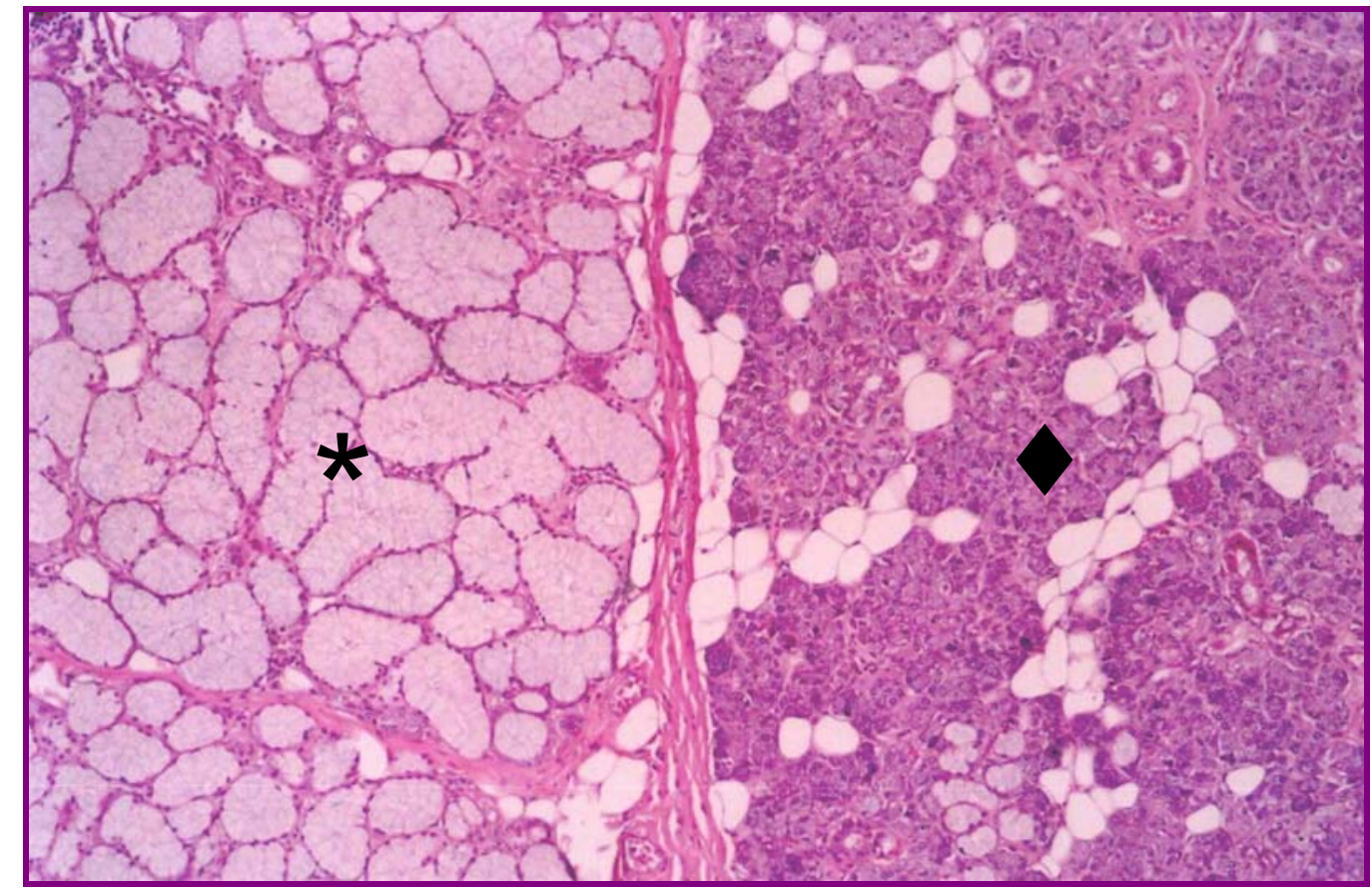

FIGURA 11 - Interface entre glândula sublingual $\left(^{*}\right)$ e glândula submandibular ( $\bullet$ ). Homem de 40 anos. (H.E.; aumento 128X) 


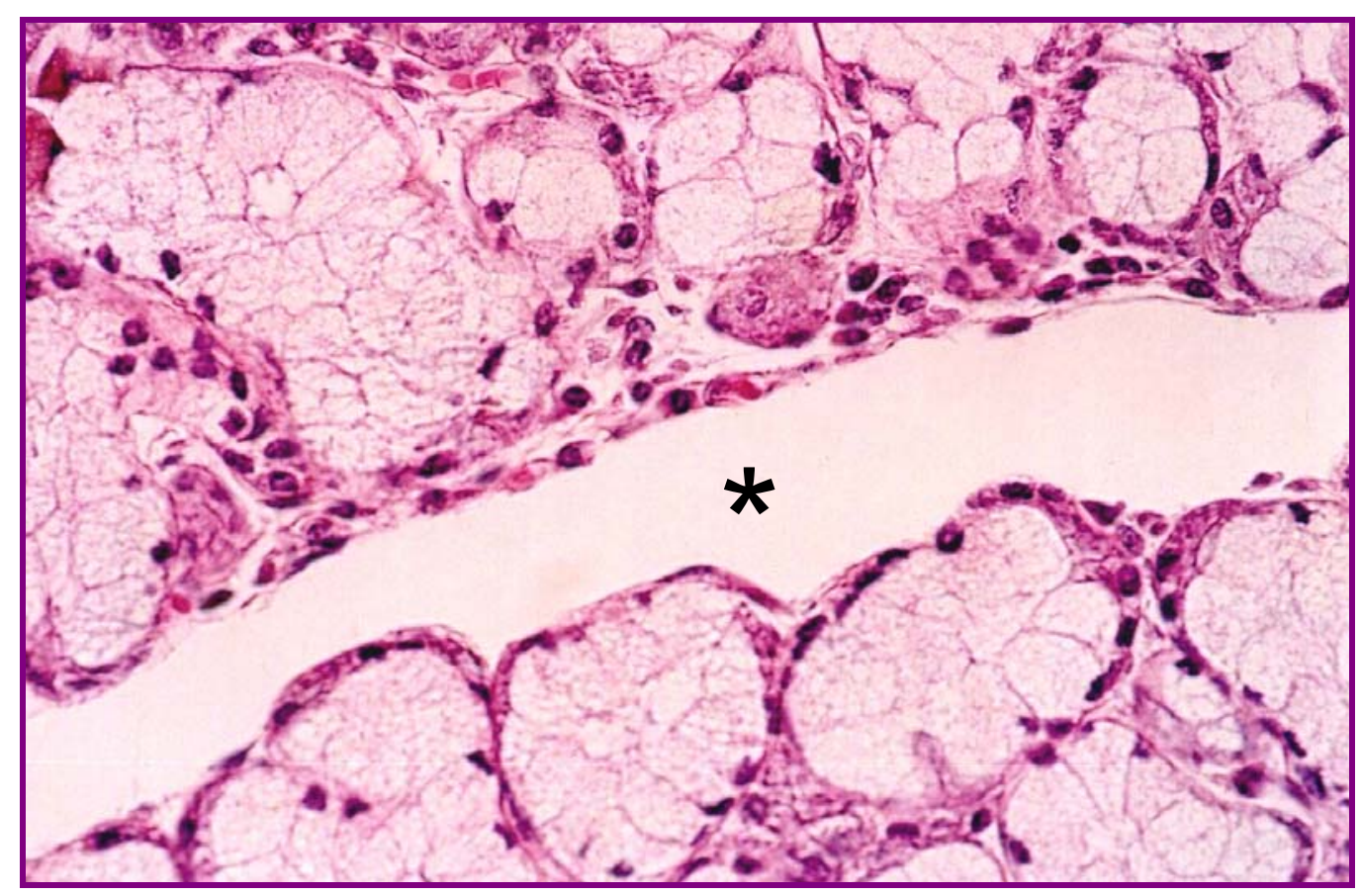

FIGURA 12 - Espaço vazio (*) em glândula sublingual. Mulher de 59 anos. (H.E.; aumento 550X)

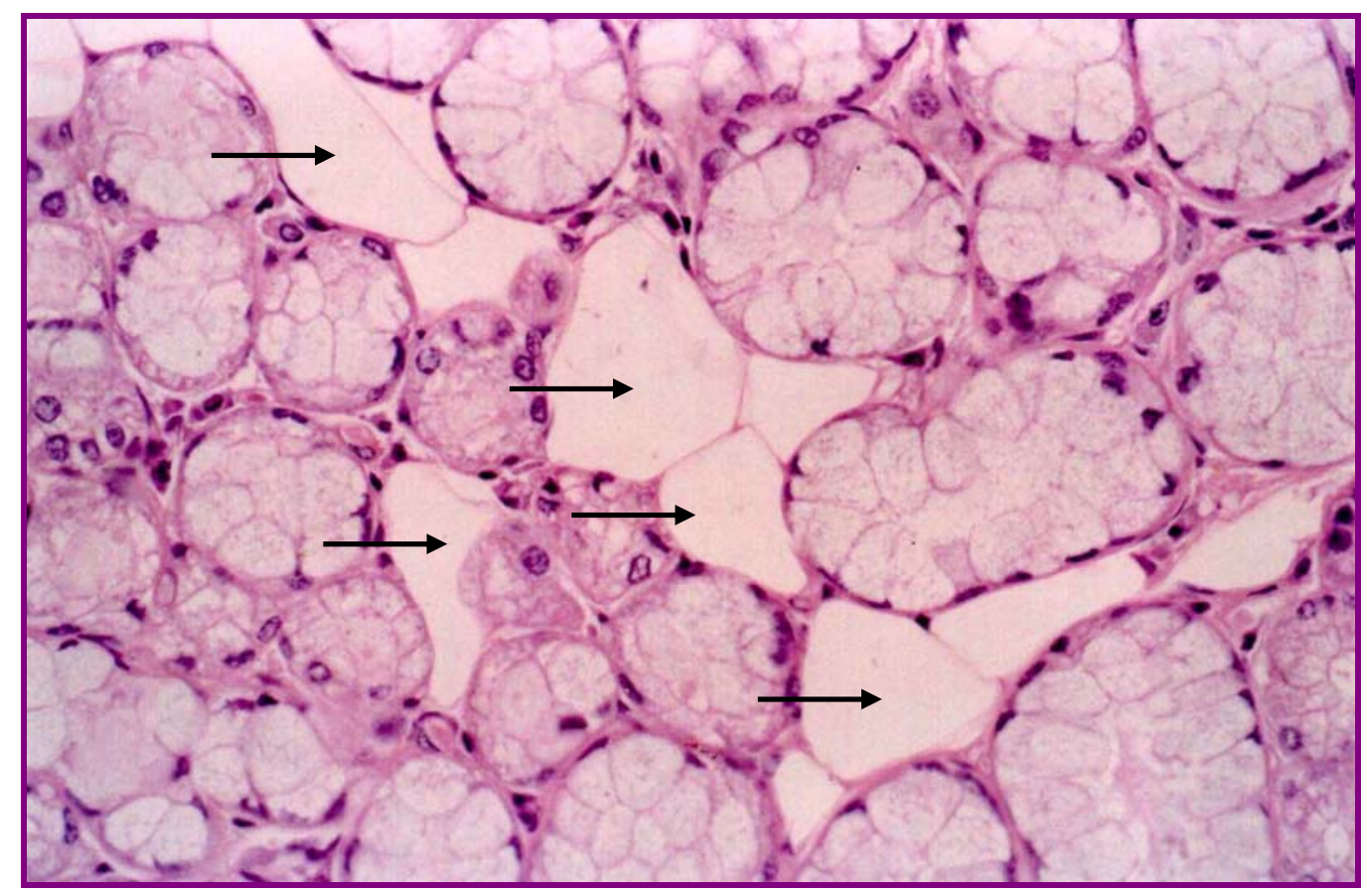

FIGURA 13 - Células adiposas (setas) entre ácinos da glândula sublingual. Homem de 30 anos. (H.E.; aumento 550X) 


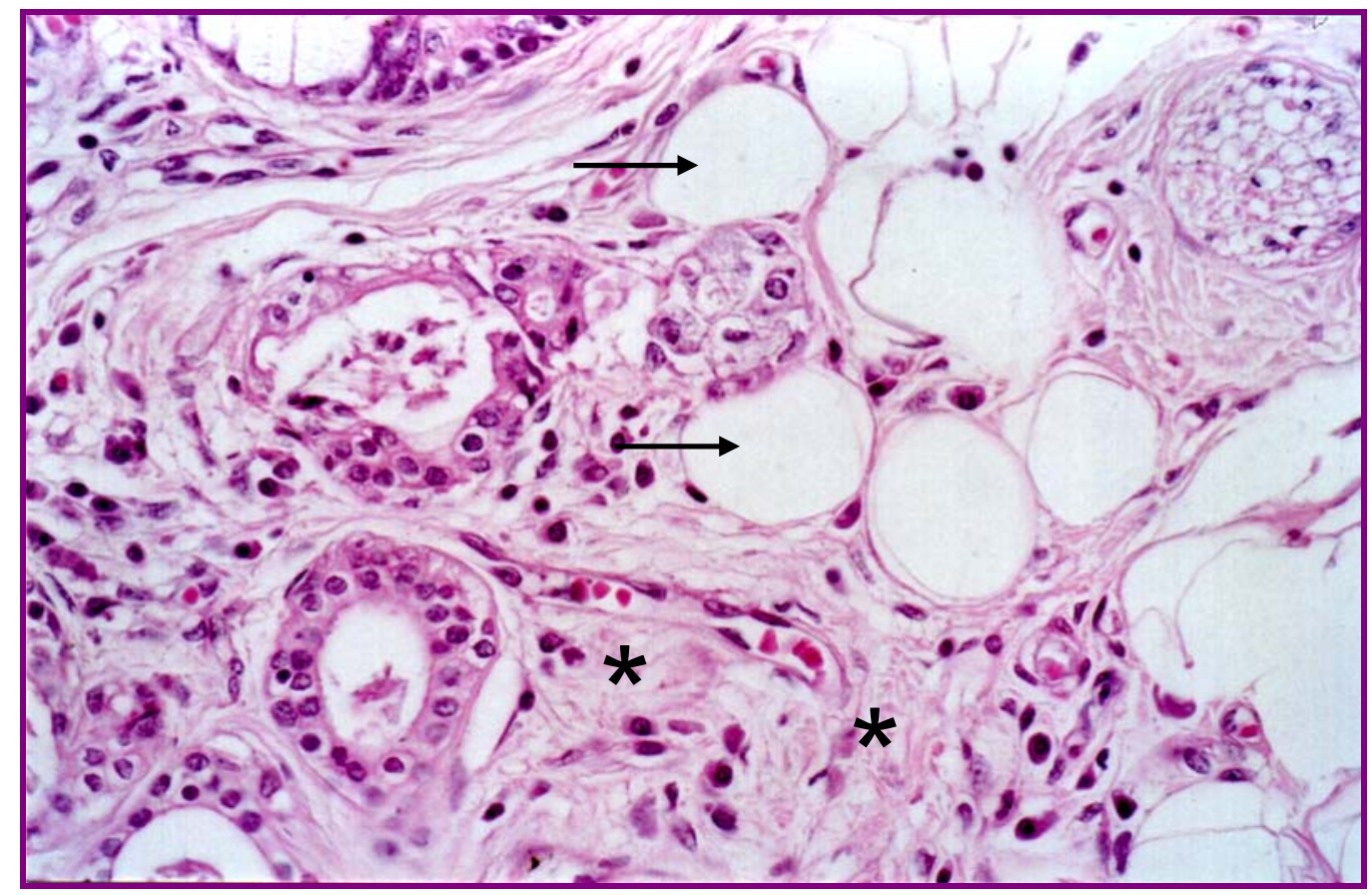

FIGURA 14 - Substituição por tecido adiposo (setas) e tecido conjuntivo $\left(^{*}\right)$. Homem de 85 anos. (H.E.; aumento 550X)

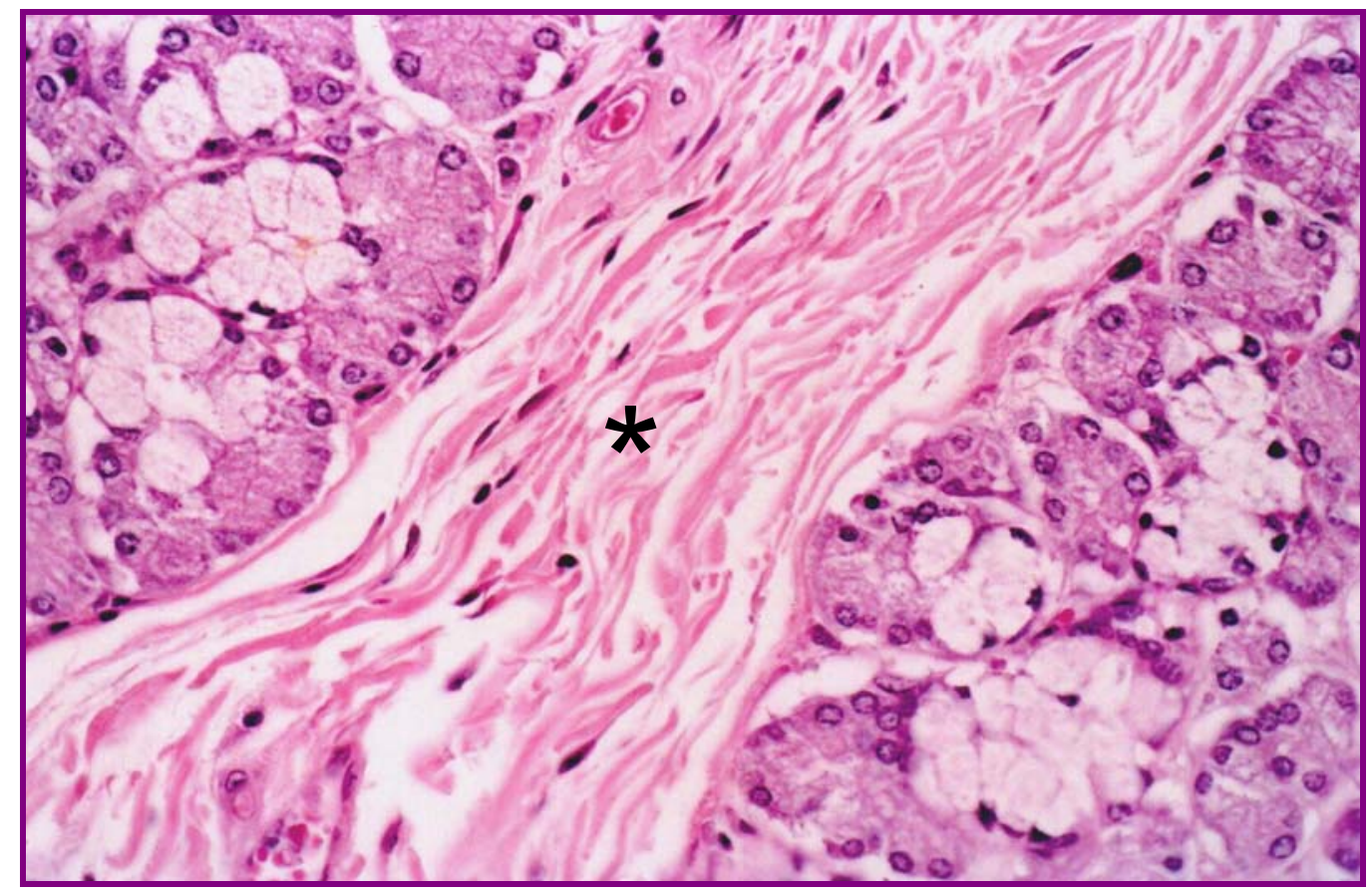

FIGURA 15 - Septo interlobular (*) em glândula sublingual. Homem de 11 anos. (H.E.; aumento 550X) 


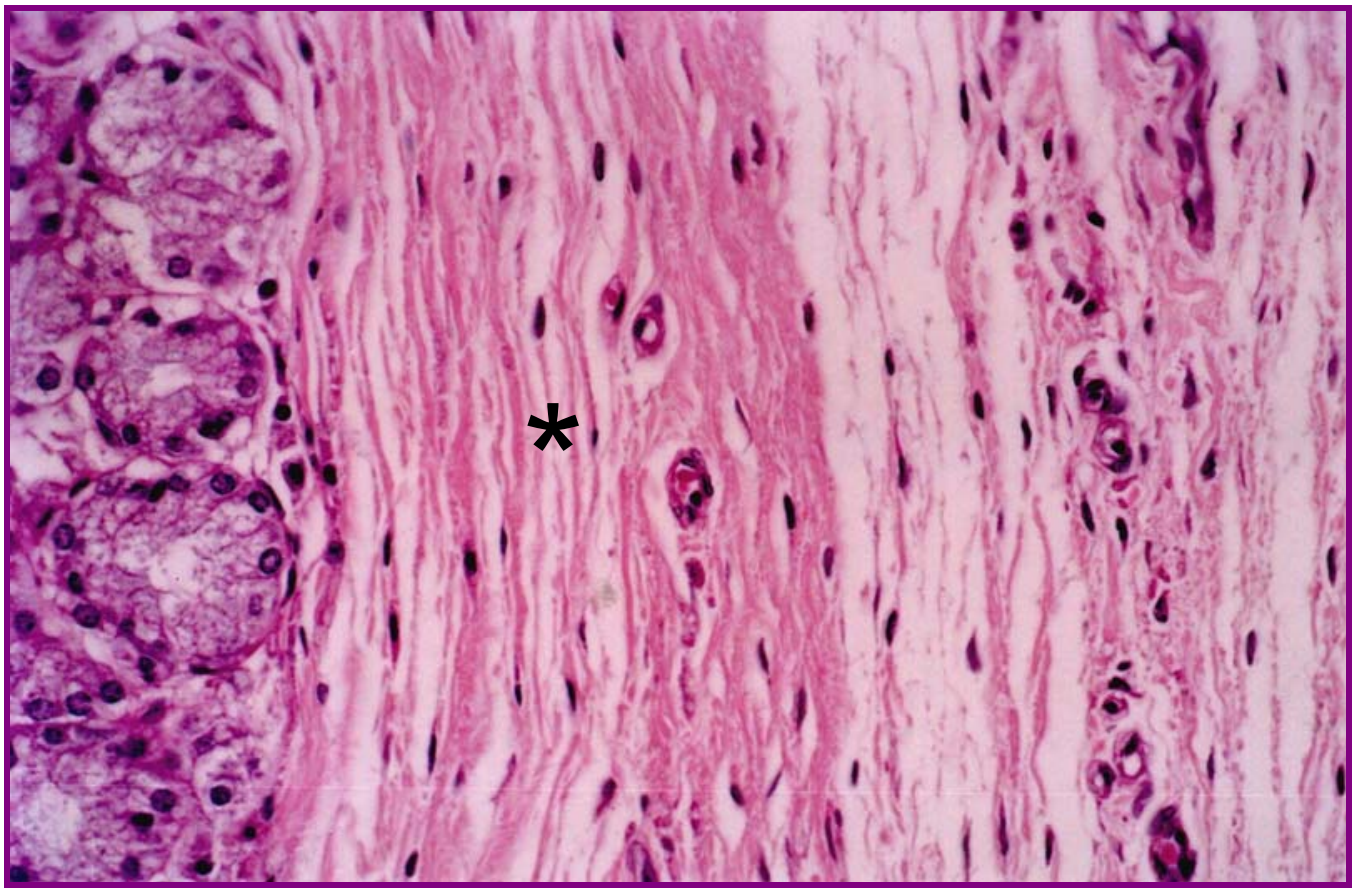

FIGURA 16 - Cápsula da glândula sublingual (*). Homem de 11 anos. (H.E.; aumento 550X)

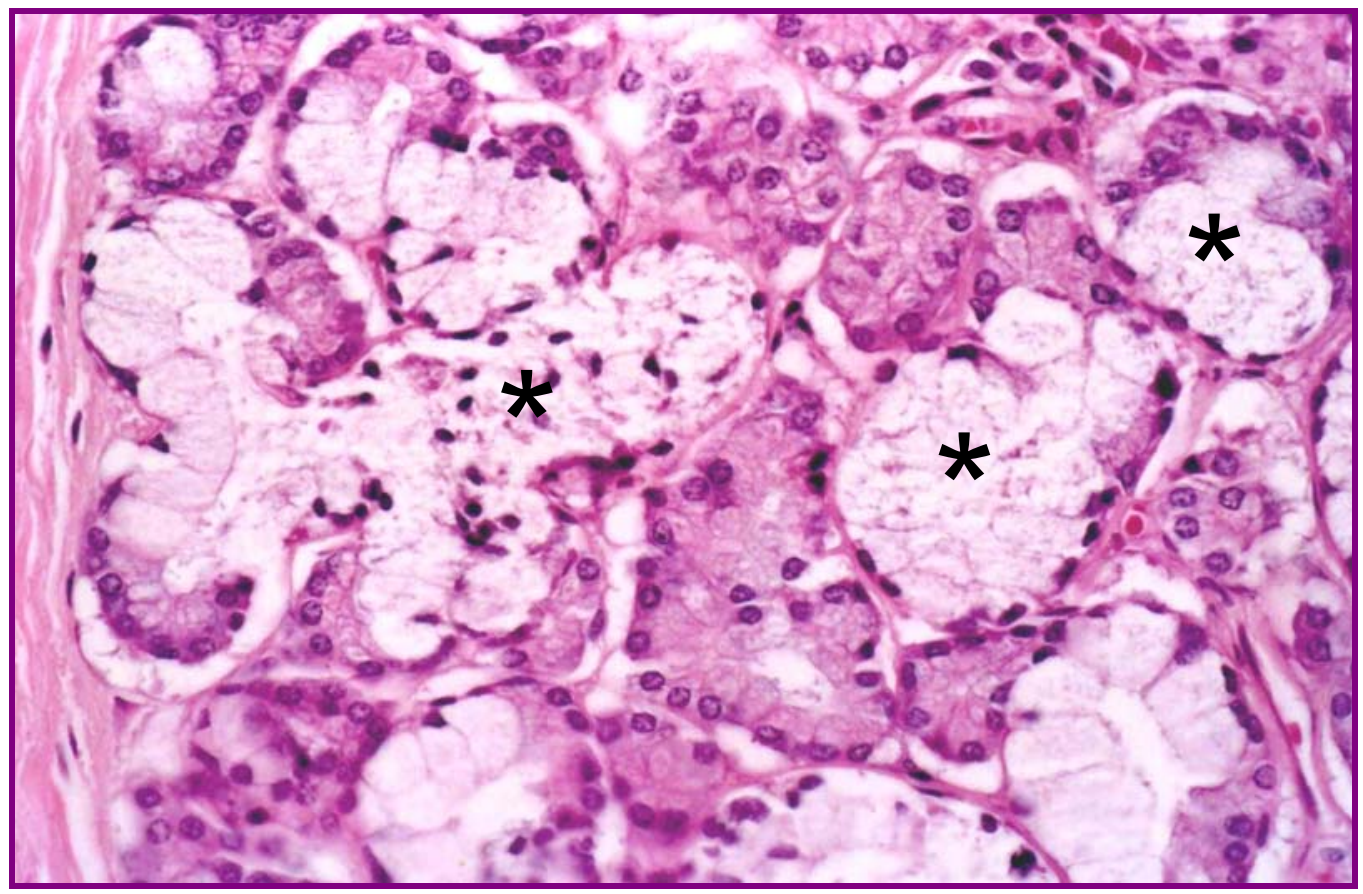

FIGURA 17 - Autólise acinar (*) em glândula sublingual. Homem de 70 anos. (H.E.; aumento 550X) 


\subsubsection{Análise estatística}

Para a análise estatística, as glândulas dos 90 indivíduos foram divididas em três grupos segundo a idade: grupo I, de 0 a 30 anos $(n=25)$, grupo II, de 31 a 60 anos ( $n=30)$, e grupo III, de 61 a 92 anos $(n=35)$.

Os valores de densidade de volume obtidos para os três grupos foram submetidos à análise de variância (ANOVA) ou ao teste de Kruskal-Wallis, seguidos pelos testes de Student-Newman-Keuls ou de Dunn.

Para a densidade de volume, os testes estatísticos foram realizados após a transformação arco-seno dos dados originais. A razão desta transformação é que a densidade de volume é expressa em percentagem, podendo não ter distribuição normal, o que impediria o confronto por testes estatísticos que pressupõem normalidade das variáveis.

A comparação entre os gêneros foi feita através do teste T-Student ou do teste de Mann-Whitney.

O volume absoluto e as relações parênquima/estroma e ácino/ductos também foram submetidas à análise de variância (ANOVA) ou ao teste de Kruskal-Wallis, seguidos pelos testes de Student-Newman-Keuls ou de Dunn.

Em todos os testes estatísticos foi adotado nível de significância de $5 \%$. O programa utilizado para as análises foi o software SigmaStat versão 1.0 (Jadel Corporation). 
Resultados 


\section{RESULTADOS}

\subsection{Densidade de volume}

A densidade de volume de ácinos, ductos, estroma, tecido adiposo e septos com a idade, está apresentada através dos seus valores médios na Figura 18.

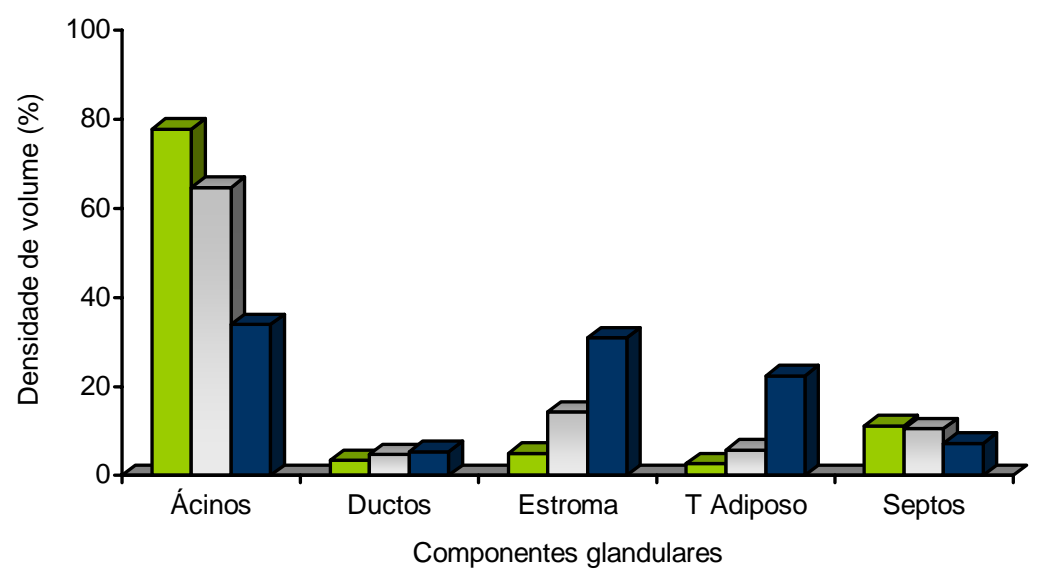

FIGURA 18 - Valores médios da densidade de volume dos componentes glandulares nos três grupos estudados

Visando melhor compreensão e descrição dos dados nos três grupos etários, a apresentação dos resultados será feita separadamente, para cada componente glandular aferido.

\subsubsection{Densidade de volume de ácinos}

A distribuição da densidade de volume de ácinos dos 90 indivíduos estudados segundo a idade, encontra-se expressa na Figura 19. Na Tabela 2 estão apresentados as médias, erros padrão das médias e desvios padrão de cada grupo etário. A Tabela 3 mostra as diferenças entre os grupos e os respectivos indicativos dos valores das probabilidades estatísticas (p) a 5\%. 


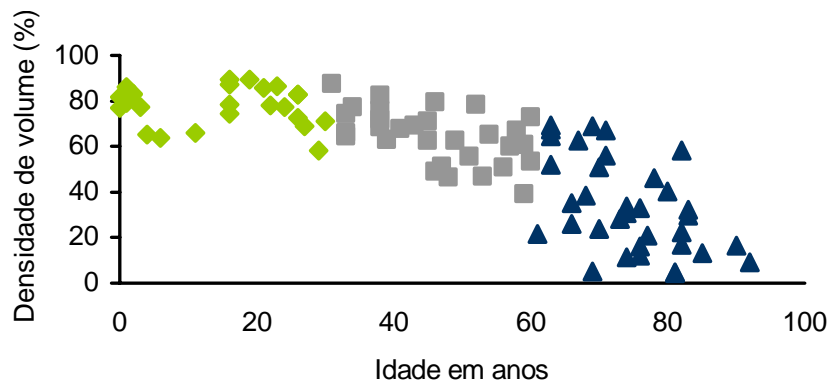

Grupo I
Grupo II
$\Delta$ Grupo III

FIGURA 19 - Distribuição da densidade de volume de ácinos dos indivíduos segundo a idade

TABELA 2 - Média da densidade de volume de ácinos nos três grupos estudados

\begin{tabular}{cccc}
\hline & GRUPO I (\%) & GRUPO II (\%) & GRUPO III (\%) \\
\hline MÉDIA & 77,76 & 64,69 & 33,94 \\
EPM & 1,696 & 2,147 & 3,498 \\
DP & 8,480 & 11,758 & 20,694 \\
\hline
\end{tabular}

Teste de Kruskal-Wallis $(\mathrm{H}=54,195 ; p<0,0001)$

EPM: erro padrão da média; DP: desvio padrão

TABELA 3 - Diferenças percentuais entre as médias da densidade de volume de ácinos dos três grupos estudados

\begin{tabular}{|c|c|c|c|c|}
\hline \multicolumn{3}{|c|}{ GRUPOS DE ESTUDO } & DENSIDADE DE VOLUME DE ÁCINOS (\%) & $P$ \\
\hline GRUPO I & $\mathrm{X}$ & GRUPO II & $-16,80$ & $p<0,05^{*}$ \\
\hline GRUPO II & $X$ & GRUPO III & $-47,54$ & $p<0,05^{*}$ \\
\hline GRUPO I & $X$ & GRUPO III & $-56,35$ & $p<0,05^{*}$ \\
\hline
\end{tabular}

Teste de Dunn; *Significante estatisticamente

\subsubsection{Densidade de volume de ductos}

A distribuição da densidade de volume de ductos dos 90 indivíduos estudados, segundo a idade, está expressa na Figura 20. As médias, erros padrão das médias e desvios padrão de cada grupo etário estão 
apresentadas na Tabela 4 e as diferenças estatísticas observadas encontram-se na Tabela 5.

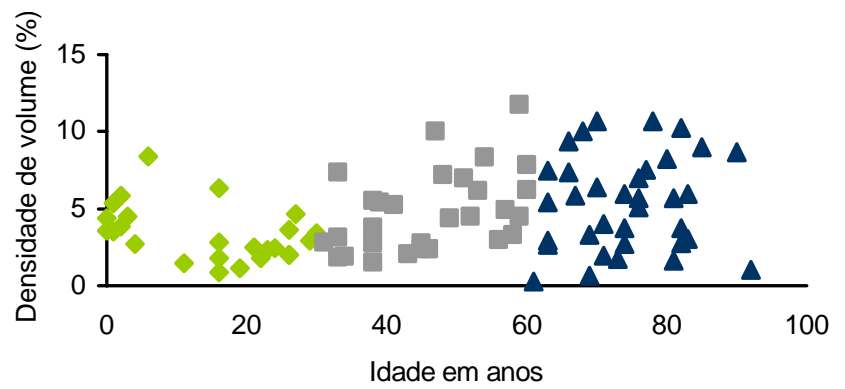

FIGURA 20 - Distribuição da densidade de volume de ductos dos indivíduos segundo a idade

TABELA 4 - Média da densidade de volume de ductos nos três grupos estudados

\begin{tabular}{cccc}
\hline & GruPO I (\%) & GruPO II (\%) & GRUPO III (\%) \\
\hline MÉDIA & 3,37 & 4,75 & 5,39 \\
EPM & 0,355 & 0,472 & 0,518 \\
DP & 1,777 & 2,585 & 3,062 \\
\hline
\end{tabular}

Análise de Variância $(\mathrm{F}=3,745 ; p=0,0275)$

EPM: erro padrão da média; DP: desvio padrão

TABELA 5 - Diferenças percentuais entre as médias da densidade de volume de ductos dos três grupos estudados

\begin{tabular}{|c|c|c|c|}
\hline \multicolumn{2}{|c|}{ GRUPOS DE ESTUDO } & DENSIDADE DE VOLUME DE DUCTOS (\%) & $P$ \\
\hline GRUPO I & X GRUPO II & 40,98 & $p>0,05^{N S}$ \\
\hline GRUPO II & X GRuPO III & 13,35 & $p>0,05^{N S}$ \\
\hline GRUPO I & X GRUPO III & 59,79 & $p<0,05^{*}$ \\
\hline
\end{tabular}




\subsubsection{Densidade de volume de estroma}

A distribuição da densidade de volume de estroma dos 90 indivíduos estudados, segundo a idade, está expressa na Figura 21. Na Tabela 6 estão apresentados as médias, erros padrão das médias e desvios padrão de cada grupo etário. A Tabela 7 mostra as diferenças estatísticas observadas entre os grupos.

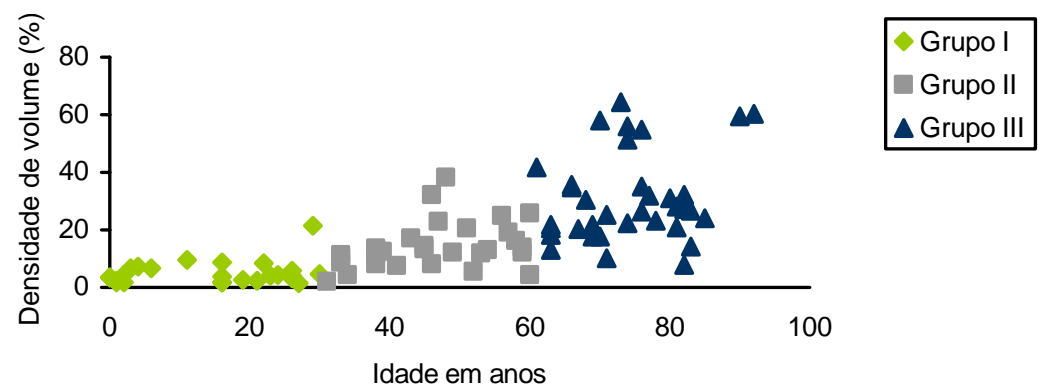

FIGURA 21- Distribuição da densidade de volume de estroma dos indivíduos segundo a idade

TABELA 6 - Média da densidade de volume de estroma nos três grupos estudados

\begin{tabular}{cccc}
\hline & GRUPO I (\%) & GRUPO II (\%) & GRUPO III (\%) \\
\hline MÉDIA & 5,02 & 14,31 & 30,98 \\
EPM & 0,829 & 1,490 & 2,615 \\
DP & 4,143 & 8,163 & 15,472 \\
\hline
\end{tabular}

Teste de Kruskal-Wallis $(\mathrm{H}=57,192 ; p<0,0001)$

EPM: erro padrão da média; DP: desvio padrão

TABELA 7 - Diferenças percentuais entre as médias da densidade de volume de estroma dos três grupos estudados

\begin{tabular}{|c|c|c|c|}
\hline \multicolumn{2}{|c|}{ GRUPOS DE ESTUDO } & \multirow{2}{*}{$\begin{array}{c}\text { DENSIDADE DE VOLUME DE ESTROMA (\%) } \\
185,33\end{array}$} & \multirow{2}{*}{$\frac{P}{p<0,05^{*}}$} \\
\hline GRUPO I $X$ & GRUPO II & & \\
\hline GRUPO II X & GRUPO III & 116,53 & $p<0,05^{*}$ \\
\hline GRUPO I X & GRUPO III & 517,82 & $p<0,05^{*}$ \\
\hline
\end{tabular}

Teste de Dunn; *Significante estatisticamente 
5.1.4 Densidade de volume de tecido adiposo

A distribuição da densidade de volume de tecido adiposo dos 90 indivíduos estudados, segundo a idade, está expressa na Figura 22. $\mathrm{Na}$ Tabela 8 estão apresentados as médias, erros padrão das médias e desvios padrão de cada grupo etário. A Tabela 9 mostra as diferenças estatísticas observadas entre os grupos.

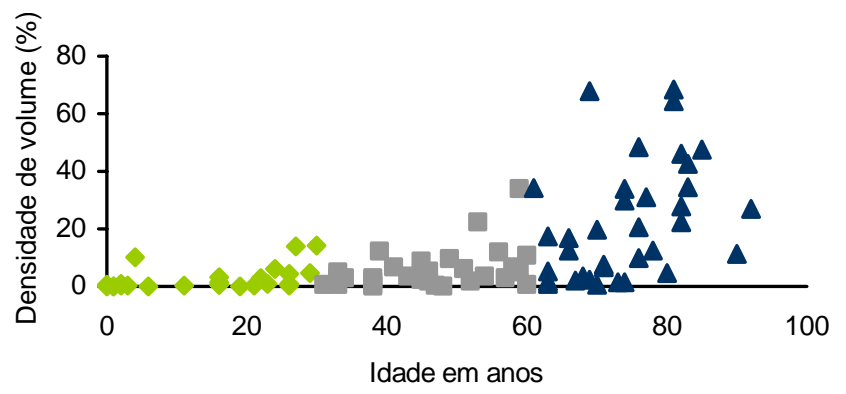

FIGURA 22- Distribuição da densidade de volume de tecido adiposo dos indivíduos segundo a idade

TABELA 8 - Média da densidade de volume de tecido adiposo nos três grupos estudados

\begin{tabular}{cccc}
\hline & GRUPO I (\%) & GRUPO II (\%) & GRUPO III (\%) \\
\hline MÉDIA & 2,67 & 5,76 & 22,42 \\
EPM & 0,842 & 1,317 & 3,409 \\
DP & 4,209 & 7,214 & 20,170 \\
\hline
\end{tabular}

Teste de Kruskal-Wallis $(\mathrm{H}=31,955 ; p<0,0001)$

EPM: erro padrão da média; DP: desvio padrão

TABELA 9 - Diferenças percentuais entre as médias da densidade de volume de tecido adiposo dos três grupos estudados

\begin{tabular}{|c|c|c|c|c|}
\hline \multicolumn{3}{|c|}{ GRUPOS DE ESTUDO } & \multirow{2}{*}{$\begin{array}{c}\text { DENSIDADE DE VOLUME DE T ADIPOSO (\%) } \\
115,30\end{array}$} & \multirow{2}{*}{$\begin{array}{c}P \\
p>0,05^{N S}\end{array}$} \\
\hline GRUPO I & $x$ & GRUPO II & & \\
\hline GRUPO II & $X$ & GRUPO III & 289,40 & $p<0,05^{*}$ \\
\hline GRUPO I & $X$ & GRUPO III & 738,36 & $p<0,05^{*}$ \\
\hline
\end{tabular}

Teste de Dunn; *Significante estatisticamente; NS: não significante estatisticamente 


\subsubsection{Densidade de volume de septos}

A distribuição da densidade de volume dos septos dos 90 indivíduos estudados, segundo a idade, está expressa na Figura 23. Na Tabela 10 estão apresentados as médias, erros padrão das médias e desvios padrão de cada grupo etário. A Tabela 11 mostra as diferenças estatísticas observadas entre os grupos.

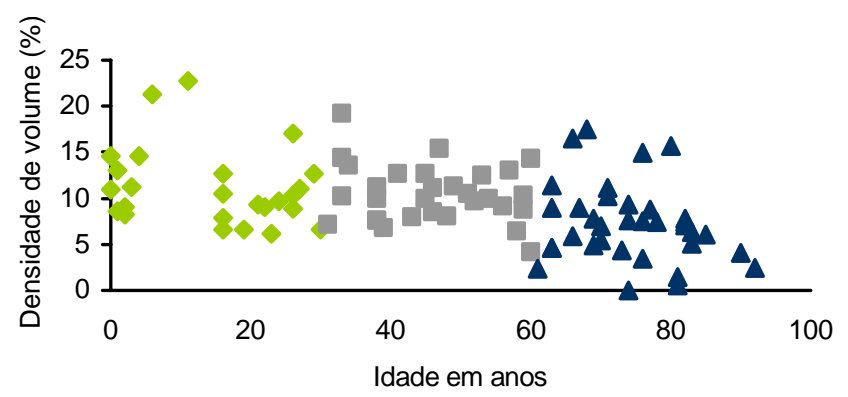

FIGURA 23 - Distribuição da densidade de volume de septos dos indivíduos segundo a idade

TABELA 10 - Média da densidade de volume de septos nos três grupos estudados

\begin{tabular}{cccc}
\hline & GRUPO I (\%) & GRUPO II (\%) & GRUPO III (\%) \\
\hline MÉDIA & 11,18 & 10,49 & 7,27 \\
EPM & 0,855 & 0,569 & 0,721 \\
DP & 4,274 & 3,116 & 4,263 \\
\hline
\end{tabular}

Análise de Variância ( $\mathrm{F}=10,616 ; p<0,0001)$

EPM: erro padrão da média; DP: desvio padrão

TABELA 11 - Diferenças percentuais entre as médias da densidade de volume de septos dos três grupos estudados

\begin{tabular}{ccccc}
\hline \multicolumn{2}{c}{ Grupos De Estudo } & Densidade De Volume De Septos (\%) & $P$ \\
\hline Grupo I & $X$ & Grupo II & $-6,24$ & $p>0,05^{N S}$ \\
Grupo II & $X$ & Grupo III & $-30,67$ & $p<0,05^{\star}$ \\
Grupo I & $X$ & Grupo III & $-35,00$ & $p<0,05^{\star}$ \\
\hline
\end{tabular}


Teste de Student-Newman-Keuls; *Significante estatisticamente; NS: não significante estatisticamente

5.1.6 Densidade de volume de parênquima e de estroma total

A densidade de volume de parênquima (ácinos e ductos) e de estroma total (estroma, tecido adiposo e septos) com a idade, está apresentada através dos seus valores médios na Figura 24. Na Tabela 12 estão apresentados as médias, erros padrão das médias e desvios padrão de cada grupo etário.

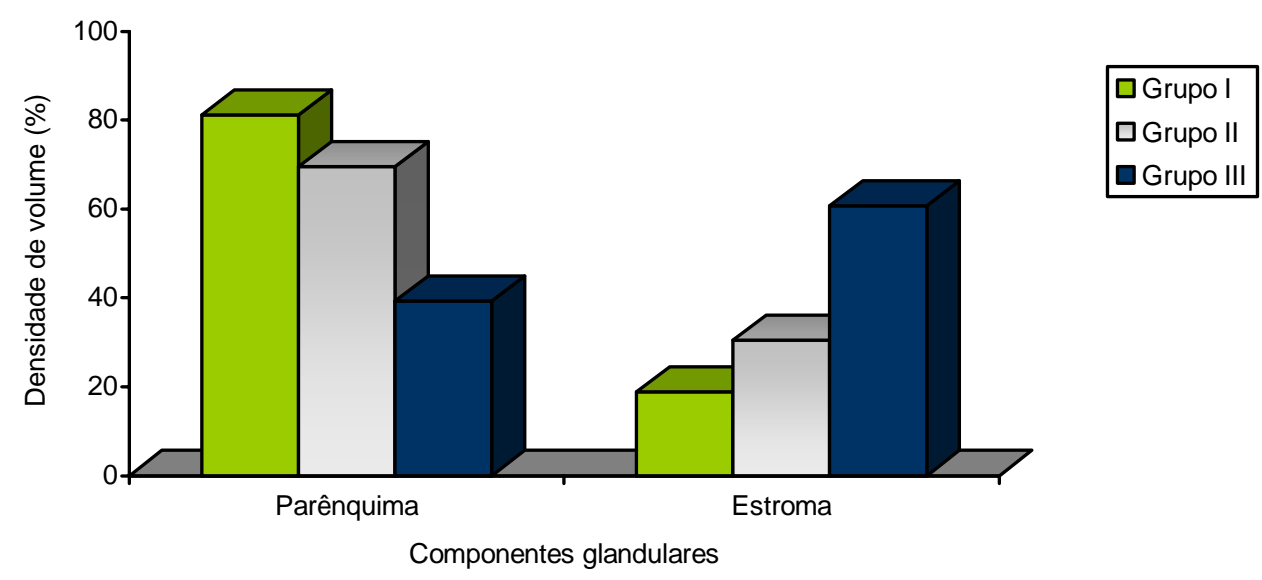

FIGURA 24 - Valores médios da densidade de volume de parênquima e de estroma total nos três grupos estudados

TABELA 12 - Média da densidade de volume de parênquima e de estroma total nos três grupos estudados

\begin{tabular}{cccccccccc}
\hline COMPONENTES & \multicolumn{3}{c}{ GRUPO I } & \multicolumn{3}{c}{ GRUPO II } & \multicolumn{3}{c}{ GRUPO III } \\
\cline { 2 - 10 } GLANDULARES & MD & EPM & DP & MD & EPM & DP & MD & EPM & DP \\
\hline PARÊNQUIMA & 81,13 & 1,625 & 8,126 & 69,44 & 1,996 & 10,934 & 39,32 & 3,543 & 20,962 \\
ESTROMA & 18,87 & 1,625 & 8,126 & 30,55 & 1,996 & 10,934 & 60,8 & 3,543 & 20,962
\end{tabular}

Teste de Kruskal-Wallis $(\mathrm{H}=54,851 ; p<0,0001)$

MD: média; EPM: erro padrão da média; DP: desvio padrão

A distribuição da densidade de volume de parênquima e de estroma total dos 90 indivíduos estudados, segundo a idade, está expressa nas Figuras 25 e 26, respectivamente. 


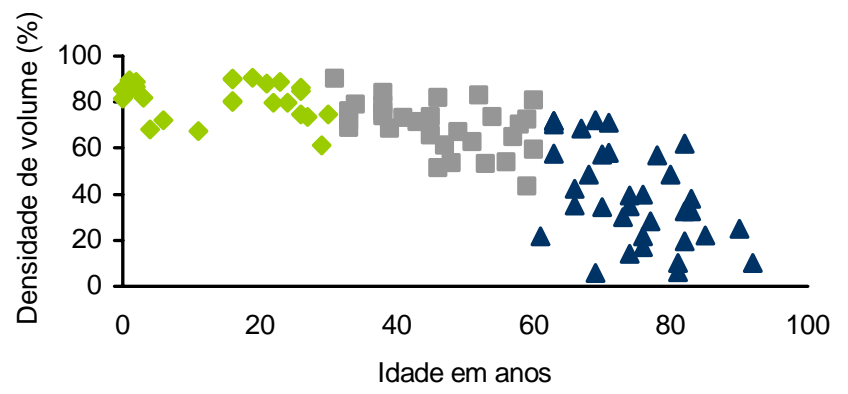

\begin{tabular}{|c|}
\hline Grupo I \\
Grupo II \\
$\Delta$ Grupo III \\
\hline
\end{tabular}

FIGURA 25 - Distribuição da densidade de volume de parênquima dos indivíduos segundo a idade

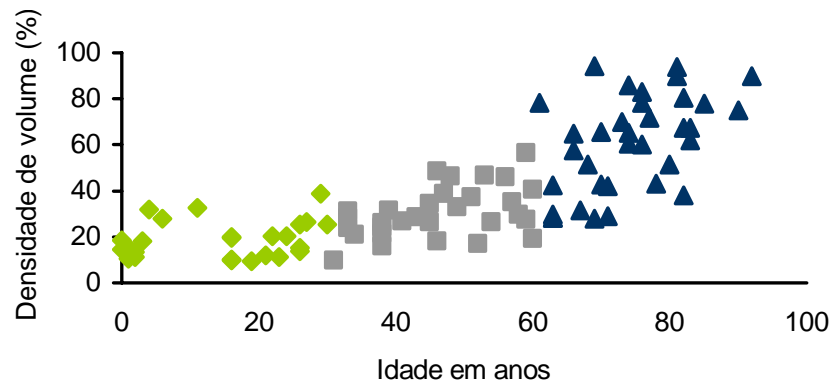

FIGURA 26 - Distribuição da densidade de volume de estroma total dos indivíduos segundo a idade

\subsection{Comparação da densidade de volume entre gêneros}

A Figura 27 mostra os valores médios da densidade de volume de ácinos, ductos, estroma, tecido adiposo e septos nos gêneros masculino e feminino. Na Tabela 13 estão apresentados as médias, erros padrão das médias e desvios padrão de cada gênero. 


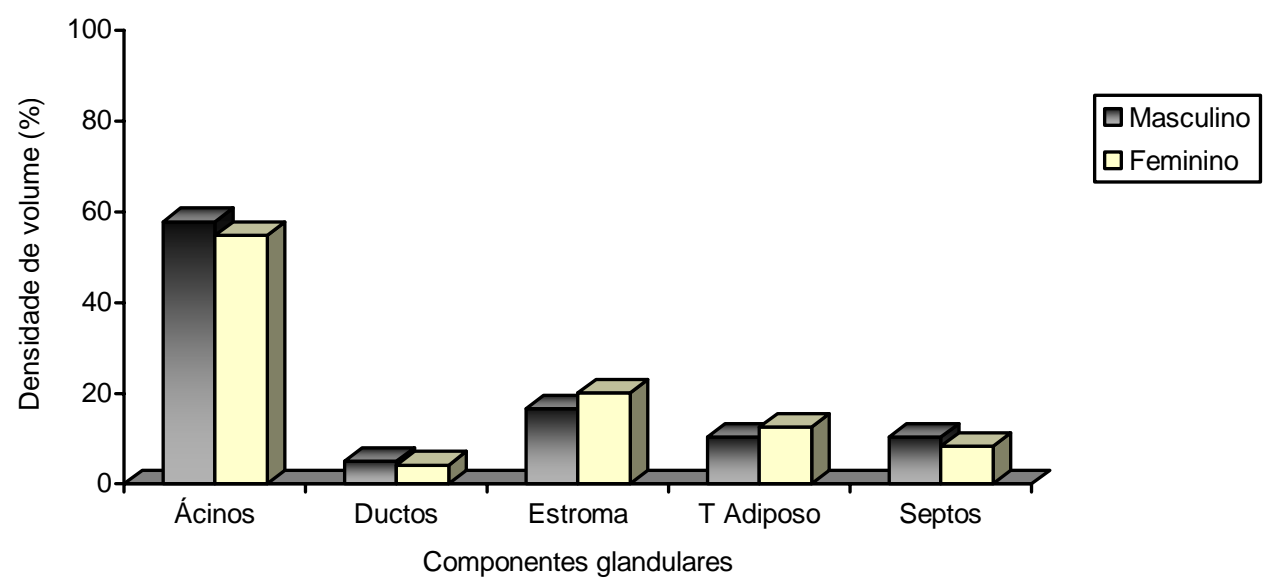

FIGURA 27 - Valores médios da densidade de volume dos vários componentes glandulares nos gêneros masculino e feminino

TABELA 13 - Média da densidade de volume dos vários componentes glandulares nos gêneros masculino e feminino

\begin{tabular}{cccccccc}
\hline COMPONENTES & \multicolumn{3}{c}{ MASCULINO (\%) } & \multicolumn{3}{c}{ FEMININO (\%) } & \multirow{2}{*}{$P$} \\
\cline { 2 - 6 } GLANDULARES & MD & EPM & DP & MD & EPM & DP & \\
\hline ÁCINOS & 57,80 & 2,999 & 20,775 & 54,72 & 4,238 & 27,463 & (MW) $p=0,8938^{N S}$ \\
DUCTOS & 4,97 & 0,384 & 2,662 & 4,21 & 0,419 & 2,716 & (MW) $p=0,1006^{N S}$ \\
ESTROMA & 16,58 & 1,872 & 12,968 & 20,08 & 2,729 & 17,686 & (TT) $p=0,3510^{N S}$ \\
T ADIPOSO & 10,28 & 1,915 & 13,268 & 12,64 & 2,900 & 18,792 & (MW) $p=0,9420^{N S}$ \\
SEPTOS & 10,38 & 0,638 & 4,417 & 8,34 & 0,591 & 3,830 & (TT) $p=0,0166^{*}$
\end{tabular}

MW: Teste de Mann-Whitney; TT: Teste T-Student; *Significante estatisticamente; NS: não significante estatisticamente

MD: média; EPM: erro padrão da média; DP: desvio padrão

\subsection{Coeficiente de variação (Erro)}

O coeficiente de variação ou "erro" associado à volumetria de contagem de pontos de cada componente glandular está expresso na Tabela 14. 
TABELA 14 - Coeficiente de variação médio dos componentes glandulares nos três grupos estudados

\begin{tabular}{cccc}
\hline $\begin{array}{c}\text { COMPONENTES } \\
\text { GLANDULARES }\end{array}$ & GRUPO I & GRUPO II & GRUPO III \\
\hline ÁcINOS & 0,75 & 1,05 & 2,50 \\
DuCTOS & 8,33 & 6,99 & 7,36 \\
ESTROMA & 7,21 & 3,96 & 2,34 \\
T ADIPOSO & 22,89 & 10,87 & 4,82 \\
SEPTOS & 4,14 & 4,24 & 5,85 \\
\hline
\end{tabular}

5.4 Volume glandular e volume absoluto por componente

A Figura 28 mostra o volume glandular dos indivíduos distribuídos segundo a idade e a Tabela 15 os valores médios de cada grupo. A Tabela 16 mostra os valores médios do volume glandular nos gêneros masculino e feminino. Na Tabela 17 estão apresentados os valores médios do volume absoluto dos vários componentes morfológicos calculados para cada grupo etário.

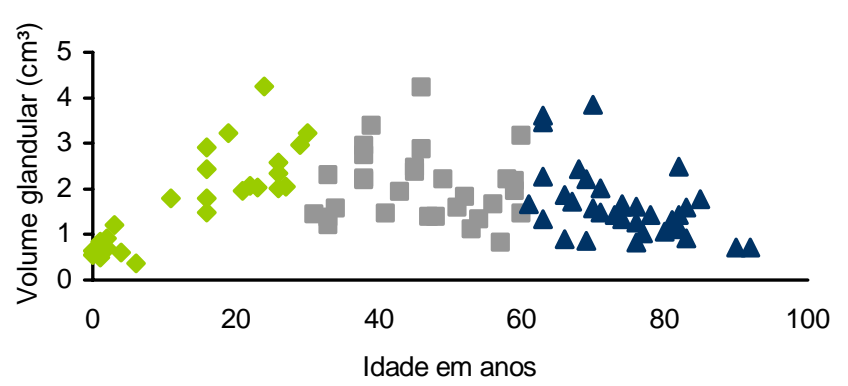

FIGURA 28 - Distribuição do volume glandular dos indivíduos segundo a idade 
TABELA 15 - Volume glandular médio $\left(\mathrm{cm}^{3}\right)$ nos três grupos estudados

\begin{tabular}{cccc}
\hline & GRUPO I & GRUPO II & GRUPO III \\
\hline MÉDIA & 1,82 & 2,04 & 1,65 \\
EPM & 0,206 & 0,138 & 0,130 \\
DP & 1,033 & 0,761 & 0,773
\end{tabular}

Teste de Kruskal-Wallis $(\mathrm{H}=4,2873 ; p=0,1172)$

EPM: erro padrão da média; DP: desvio padrão

TABELA 16 - Volume glandular médio $\left(\mathrm{cm}^{3}\right)$ nos gêneros masculino e feminino

\begin{tabular}{ccc}
\hline & MASCULINO & FEMININO \\
\hline MÉDIA & 1,95 & 1,69 \\
EPM & 0,126 & 0,127 \\
DP & 0,876 & 0,824 \\
\hline
\end{tabular}

Teste de Mann-Whitney $(p=0,0933)$

EPM: erro padrão da média; DP: desvio padrão

TABELA 17 - Volume absoluto médio ( $\mathrm{VT}$ ), em $\mathrm{cm}^{3}$, dos vários componentes glandulares nos três grupos estudados

\begin{tabular}{|c|c|c|c|c|c|}
\hline & VT ÁCINOS & Vt Ductos & VT ESTROMA & VT T ADIPOSO & Vt SePtos \\
\hline \multicolumn{6}{|l|}{ GRUPO I } \\
\hline MÉDIA & 1,42 & 0,05 & 0,10 & 0,06 & 0,19 \\
\hline EPM & 0,165 & 0,006 & 0,025 & 0,023 & 0,022 \\
\hline DP & 0,826 & 0,028 & 0,127 & 0,113 & 0,112 \\
\hline \multicolumn{6}{|l|}{ GRUPO II } \\
\hline MÉDIA & 1,33 & 0,09 & 0,29 & 0,12 & 0,21 \\
\hline EPM & 0,102 & 0,010 & 0,043 & 0,028 & 0,017 \\
\hline DP & 0,557 & 0,054 & 0,235 & 0,152 & 0,092 \\
\hline \multicolumn{6}{|c|}{ GRUPO III } \\
\hline MÉDIA & 0,65 & 0,09 & 0,46 & 0,32 & 0,12 \\
\hline EPM & 0,102 & 0,012 & 0,038 & 0,047 & 0,016 \\
\hline DP & 0,605 & 0,068 & 0,224 & 0,278 & 0,092 \\
\hline
\end{tabular}

EPM: erro padrão da média; DP: desvio padrão 


\subsubsection{Relação parênquima/estroma e ácinos/ductos}

As Figuras 29 e 30 expressam, respectivamente, a distribuição das relações parênquima/estroma e ácinos/ductos dos indivíduos segundo a idade. Os valores médios dessas relações nos três grupos estudados encontram-se, respectivamente, nas Tabelas 18 e 19.

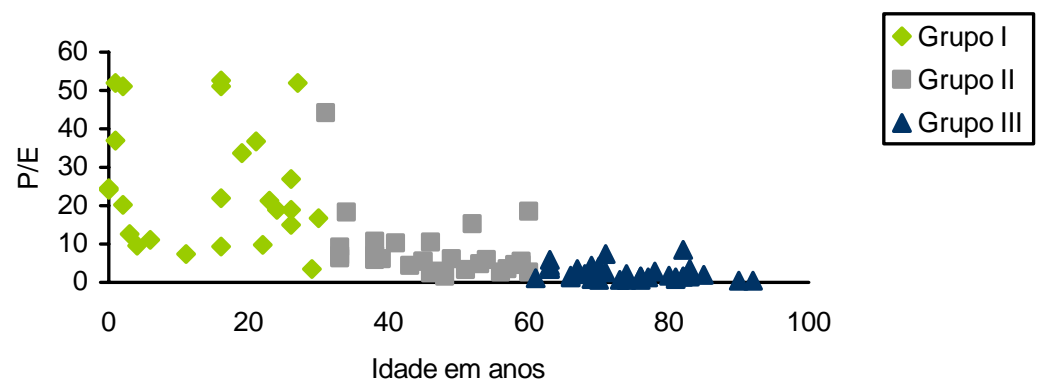

FIGURA 29 - Distribuição da relação parênquima/estroma dos indivíduos segundo a idade

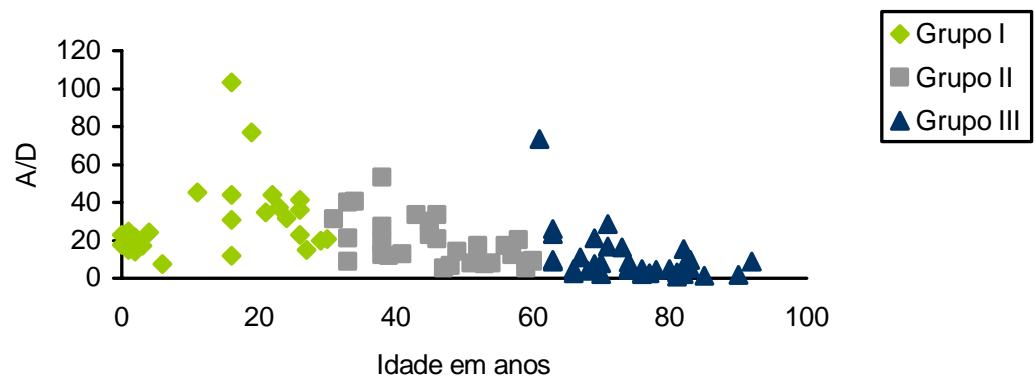

FIGURA 30 - Distribuição da relação ácinos/ductos dos indivíduos segundo a idade

TABELA 18 - Média da relação parênquima/estroma nos três grupos estudados

\begin{tabular}{cccc}
\hline & GRUPO I & GRUPO II & GRUPO III \\
\hline MÉDIA & 25,51 & 8,01 & 2,34 \\
EPM & 3,179 & 1,473 & 0,324 \\
DP & 15,893 & 8,069 & 1,919 \\
\hline
\end{tabular}

Teste de Kruskal-Wallis $(\mathrm{H}=60,118 ; p<0,0001)$ 
EPM: erro padrão da média; DP: desvio padrão

TABELA 19 - Média da relação ácinos/ductos nos três grupos estudados

\begin{tabular}{cccc}
\hline & GRUPO I & GRUPO II & GRUPO III $^{\mathrm{A}}$ \\
\hline MÉDIA & 31,16 & 18,85 & 10,23 \\
EPM & 4,220 & 2,247 & 2,227 \\
DP & 21,101 & 12,309 & 13,177
\end{tabular}

Teste de Kruskal-Wallis $\left(\mathrm{H}=33,548 ; p<0,0001^{*}\right)$

* grupos com a mesma letra não possuem diferença estatisticamente significante entre si EPM: erro padrão da média; DP: desvio padrão 


\section{Discussão}




\section{DISCUSSÃO}

\subsection{Da metodologia}

\subsubsection{Da casualização dos campos microscópicos}

No presente trabalho utilizamos, para as quantificações morfométricas ao microscópio, a casualização dos campos histológicos por amostragem sistemática (WEIBEL ${ }^{33}$, 1969). Nesse sistema de amostragem, os 51 campos histológicos usados nas quantificações foram distribuídos de forma homogênea entre os três cortes, de cada glândula, para representar o todo. Isto porque a metodologia adotada na macroscopia produziu um corte central que era sempre maior que o anterior e o posterior. Como, em certos casos, havia uma diferença muito grande de tamanho entre as glândulas, foi necessário primeiramente mapear os cortes selecionados e obter o número total de campos de cada um. Desta forma, à partir do total de campos histológicos representativos de cada glândula foi possível distribuir os 51 campos pré-estabelecidos para as contagens, proporcionalmente, à área total dos cortes, ou seja, o intervalo regular entre os campos contados foi maior ou menor para cada glândula dependendo do tamanho dos seus cortes.

Por ser extremamente trabalhoso, o mapeamento dos cortes histológicos foi feito em 30 indivíduos. Nos 60 indivíduos restantes, o intervalo entre os campos usados nas contagens foi estabelecido mediante comparação visual entre os tamanhos dos cortes por sobreposição das lâminas.

O número total de campos por indivíduo (51) foi pré-estabelecido a partir de um estudo piloto onde, numa mesma glândula escolhida aleatoriamente, as contagens foram realizadas duas vezes, na primeira vez em 51 campos e na segunda em 237 campos, sendo a última equivalente a $10 \%$ do total dos campos. O confronto dos resultados obtidos nas duas contagens mostrou diferenças estatisticamente desprezíveis. Deste modo, 
os 51 campos (5100 pontos) mostraram-se suficientes para a quantificação dos fenômenos estudados. Vale destacar que esses cuidados tomados na aplicação dessa metodologia foram maiores devido a variação individual observada em humanos. Em animais, a uniformidade de tamanho das peças permite excelente aferição quantitativa com um número de campos significativamente menor (PARDINI $\left.{ }^{19}, 1985\right)$.

Convém ressaltar que, poucos detalhes de metodologia empregada são apresentados nos estudos morfométricos em glândulas salivares humanas (WATERHOUSE et al. ${ }^{32}$, 1973; SCOTT $^{22}$, 1977a; SCOTT $^{24}$, 1980; DRUMMOND; CHISHOLM ${ }^{11}$, 1984; SCOTT; FLOWER; BURNS²7, 1987; DAYAN et al. ${ }^{9}, 2000$; VERED et al. $^{31}$, 2000). Apesar de utilizarem a mesma metodologia de volumetria relativa de contagem de pontos aqui utilizada, há variações no tipo de retículo empregado e no número de pontos contados. Assim, nosso estudo piloto, levado a efeito após a calibração do observador, garantiu a segurança do método para retratar os fenômenos pesquisados.

\subsubsection{Dos critérios adotados nas quantificações}

No processo de atrofia em glândulas salivares, os ácinos podem se assemelhar a ductos (SCOTT $\left.{ }^{23}, 1977 \mathrm{~b}\right)$, sendo chamados de estruturas ductiformes. Nessa situação, a diferenciação entre ácinos e ductos se torna inviável. Quando frente a casos semelhantes, contamos como ducto as estruturas que não possuíam nenhuma célula acinosa. Em outras palavras, mesmo que uma porção do ácino já tivesse assumido aparência de ducto, mas, estivesse ainda presente alguma célula acinosa, o ponto era contado como ácino.

A oncocitose, já descrita como um achado histológico que surge com o envelhecimento (DRUMMOND; CHISHOLM ${ }^{11}$, 1984; SCOTT; FLOWER; BURNS $^{27}, 1987$; AZEVEDO ${ }^{1}$, 2003), não foi aferida separadamente. Como a detecção de oncócitos ocorreu apenas em situações eventuais, a estrutura era marcada como ácino quando a célula sob o ponto estava num ácino. Era marcada como ducto quando fizesse parte de um ducto. 
A aferição do estroma, separadamente em septos, tecido conjuntivo e tecido adiposo, foi feita para que o fenômeno de substituição do parênquima por estroma com a idade fosse melhor discriminado. Entretanto, em alguns campos histológicos, principalmente em indivíduos de idade avançada onde havia substituição parênquima-estromal marcante, sentimos dificuldade na diferenciação entre septo e tecido conjuntivo. Por essa razão, além dos resultados isolados, a soma dos valores de estroma, tecido adiposo e septos, chamados aqui de estroma total, também foram apresentados (Figuras 24 e 26).

\subsection{Dos resultados}

\subsubsection{Da densidade de volume}

As descrições morfológicas das alterações de glândulas sublinguais humanas com a idade (AZEVEDO $\left.{ }^{1}, 2003\right)$, foram confirmadas na presente investigação através da análise morfométrica. Assim, a diminuição de ácinos e o aumento de ductos e/ou estruturas ductiformes, tecido conjuntivo e tecido adiposo ficou claramente demonstrada pelos valores médios da densidade de volume dos referidos componentes, nos grupos etários estudados (Figura 18).

Seguindo a forma de apresentação dos resultados, a discussão será realizada por componente glandular aferido. Procuramos comparar os nossos resultados com os obtidos morfometricamente nas outras glândulas salivares humanas, relacionando os dados e demonstrando o efeito sistêmico do envelhecimento.

\subsubsection{Densidade de volume de ácinos}

A diminuição da densidade de volume de ácinos foi nítida com 0 avançar da idade (Figura 19). Houve diferença estatisticamente significante entre os grupos $(\mathrm{H}=54,195 ; p<0,0001$ - Tabela 2). Embora todas as diferenças entre grupos sejam estatisticamente significantes, destaca-se a marcante diminuição de 56,35\% entre os grupos I e III (Tabela 3). 
Salientamos que a perda do componente acinar com a idade, nas glândulas salivares humanas, tem sido relatada por vários pesquisadores (WATERHOUSE et al. ${ }^{32}, 1973$; SCOTT $^{22}$, 1977a; SCOTT $^{24}$, 1980; DRUMMOND; CHISHOLM ${ }^{11}$, 1984; SCOTT; FLOWER; BURNS ${ }^{27}$, 1987; DAYAN et al. ${ }^{9}, 2000$; VERED et al. ${ }^{31}$, 2000; TAKAHASHI et al.. ${ }^{30}, 2002$; AZEVEDO $^{1}$, 2003), sendo em torno de 32\% na parótida (SCOTT; FLOWER; BURNS $^{27}$, 1987), 37\% na submandibular (SCOTT ${ }^{22}$, 1977a), 28,5\% a 49,3\% nas labiais (SCOTT ${ }^{24}$, 1980; DRUMMOND; CHISHOLM ${ }^{11}$, 1984; VERED et al. ${ }^{31}, 2000$ ) e $48 \%$ nas palatinas (DAYAN et al. $^{9}, 2000$ ). Nossos resultados mostram que o fenômeno se repete em glândulas sublinguais, indo ao encontro das demais pesquisas, o que representa inexoravelmente o envelhecimento do parênquima glandular.

\subsubsection{Densidade de volume de ductos}

Com a idade, observou-se o aumento da densidade de volume de ductos (Figura 20). Este crescimento é evidente na comparação entre as médias ( $\mathrm{F}=3,745 ; p=0,0275$ - Tabela 4). Porém, apenas entre os grupos I e III a diferença observada entre as médias $(59,79 \%)$ foi estatisticamente significante (Tabela 5).

O aumento de ductos com a idade já foi descrito anteriormente (SCOTT $^{22}$, 1977a; SCOTT ${ }^{24}$, 1980; DRUMMOND; CHISHOLM ${ }^{11}$, 1984; SCOTT; FLOWER; BURNS ${ }^{27}$, 1987; DAYAN et al. ${ }^{9}$, 2000; VERED et al. ${ }^{31}$, 2000; TAKAHASHI et al. ${ }^{30}$, 2002; AZEVEDO ${ }^{1}$, 2003), sendo em torno de 2,9\% na parótida (SCOTT; FLOWER; BURNS ${ }^{27}, 1987$ ), 26\% na submandibular (SCOTT $\left.{ }^{22}, 1977 \mathrm{a}\right), 21,15 \%$ a $111 \%$ nas labiais $\left(\mathrm{SCOTT}^{24}\right.$, 1980; DRUMMOND; CHISHOLM ${ }^{11}$, 1984; VERED et al. ${ }^{31}$, 2000) e 177\% nas palatinas (DAYAN et al. $\left.{ }^{9}, 2000\right)$. Nossos resultados vão ao encontro dos resultados acima. Parece que o fenômeno representa o processo final da atrofia de um ácino (SCOTT ${ }^{23}$, 1977b; SCOTT; FLOWER; BURNS ${ }^{27}$, 1987) e, por não garantir que sejam verdadeiros ductos, os autores preferem denominá-los estruturas ductifomes. 


\subsubsection{Densidade de volume de estroma}

O estroma sofreu um aumento marcante com o passar dos anos, como pode ser notado na Figura 21. Houve diferença estatisticamente significante entre os grupos $(\mathrm{H}=57,192 ; p<0,0001$ - Tabela 6$)$. O percentual de aumento da densidade de volume de estroma entre os grupos demonstra, claramente, o quanto que a porção ocupada por este componente cresceu com a idade (Tabela 7).

O aumento do estroma com o envelhecimento é um fenômeno conhecido nas glândulas salivares humanas (WATERHOUSE et al. ${ }^{32}$, 1973; SCOTT $^{22}$, 1977a; SCOTT ${ }^{24}$, 1980; DRUMMOND; CHISHOLM ${ }^{11}$, 1984; SCOTT; FLOWER; BURNS ${ }^{27}$, 1987; DAYAN et al. ${ }^{9}$, 2000; VERED et al. ${ }^{31}$, 2000; TAKAHASHI et al. ${ }^{30}, 2002 ;$ AZEVEDO $\left.^{1}, 2003\right)$. A comparação de resultados fica limitada por diferenças nos critérios utilizados para quantificar este componente. Assim, SCOTT; FLOWER; BURNS ${ }^{27}$ (1987), verificaram que, na parótida, o tecido vascular, representado por vasos sangüíneos e linfáticos, aumentou $29,8 \%$, e os outros componentes agrupando tecido conjuntivo, nervos e infiltrado inflamatório, sofreram um acréscimo de 26,6\%. Utilizando os mesmos critérios na submandibular, SCOTT ${ }^{22}$ (1977a), observou um aumento de 59,64\% no tecido vascular com a idade. Nas glândulas labiais, os vasos sangüíneos e linfáticos aumentaram de 8,57\% (DRUMMOND; CHISHOLM ${ }^{11}$, 1984) a 138\% (VERED et al. ${ }^{31}, 2000$ ) e o tecido conjuntivo de 49,32\% (DRUMMOND; CHISHOLM ${ }^{11}$, 1984) a 60\% (VERED et al. ${ }^{31}$, 2000). Nas glândulas palatinas, os acréscimos foram de $54,5 \%$ e 511,9\%, respectivamente, para vasos sangüíneos e linfáticos, e infiltrado inflamatório; a diminuição de 16,5\% no tecido conjuntivo foi atribuída à substituição por tecido adiposo (DAYAN et al. ${ }^{9}, 2000$ ).

No presente trabalho, nós não individualizamos componentes estromais como os autores acima. Em alguns trabalhos (SCOTT ${ }^{22}$, 1977a; DRUMMOND; CHISHOLM ${ }^{11}$, 1984; SCOTT; FLOWER; BURNS ${ }^{27}$, 1987; DAYAN et al. $^{9}$, 2000; VERED et al. $^{31}$, 2000), a contagem de vasos sangüíneos e linfáticos foi realizada separadamente do estroma. Como a freqüência destas estruturas era baixa, o erro no grau de precisão do 
método de aferição seria muito alto. Apesar de individualizarmos os septos, o tecido conjuntivo intralobular e o tecido adiposo, contamos os vasos, nervos e células inflamatórias sob os pontos do retículo de integração da ocular do microscópio como estroma. O objetivo foi ter uma visão mais completa do componente estromal. Assim mesmo, nossos resultados se assemelharam aos da literatura.

\subsubsection{Densidade de volume de tecido adiposo}

O tecido adiposo foi outro componente morfológico que sofreu crescimento considerável com o avançar da idade, como está demonstrado na distribuição da densidade de volume da amostra na Figura 22. Houve diferenças estatisticamente significantes entre os grupos $(H=31,955 ; p<$ 0,0001 - Tabela 8). O crescimento de 738,36\% no componente adiposo entre os grupos I e III foi maior dentre todos os outros observados nos vários compartimentos glandulares (Tabela 9).

Outros estudos já haviam mostrado o notável crescimento do tecido adiposo em glândulas salivares humanas com o avanço da idade. Assim, aumentos de 44\%, 252,4\%, 2768\% e 130\%, foram observados, respectivamente, nas glândulas parótidas (SCOTT; FLOWER; BURNS ${ }^{27}$, 1987), submandibulares (SCOTT $\left.{ }^{22}, 1977 a\right)$, labiais (VERED et al. $\left.{ }^{31}, 2000\right) \mathrm{e}$ palatinas (DAYAN et al. ${ }^{9}$, 2000). No trabalho morfológico de AZEVEDO ${ }^{1}$ (2003), a correlação do aumento do tecido adiposo com a idade foi alta e significante, representando o segundo componente mais importante do processo de substituição parenquimatosa.

\subsubsection{Densidade de volume de septos}

A densidade de volume de septos apresentou um declínio com a idade (Figura 23). Esta diminuição foi notada entre as médias ( $F=10,616 ; p<$ 0,0001 - Tabela 10). Embora a diminuição na densidade de volume dos septos tenha sido de $30,67 \%$ e $35 \%$ entre os grupos II e III e, grupos I e III, respectivamente, diferenças estas estatisticamente significantes (Tabela 11), 
a distribuição gráfica desta variável na Figura 23 não nos mostra claramente essas diferenças.

Acreditamos que este declínio é devido à diminuição dos lóbulos e a sua substituição por tecido conjuntivo e tecido adiposo. Salientamos que estes tecidos de substituição preenchiam os lóbulos das glândulas, às vezes, sem respeitar os limites dos septos, englobando-os e unificando os lóbulos. Delimitar os septos no meio do tecido conjuntivo de substituição em indivíduos mais velhos foi uma tarefa muito difícil.

\subsubsection{Densidade de volume de parênquima e de estroma total}

Com o objetivo de melhor destacar as transformações com a idade e facilitar a comparação com dados de outros pesquisadores, juntamos os valores obtidos para os ácinos e ductos como parênquima, e os valores de septos, tecido conjuntivo e tecido adiposo como estroma total.

Observando as Figuras 24, 25 e 26 e os dados da Tabela 12 percebese claramente que a densidade de volume de parênquima diminuiu com a idade, com diferenças estatisticamente significantes entre os três grupos estudados ( $\mathrm{H}=54,851 ; p<0,0001)$, e que a densidade de volume de estroma aumentou entre os grupos também com diferenças significantes entre eles $(\mathrm{H}=54,851 ; p<0,0001)$.

Salienta-se que, a diminuição de parênquima e o aumento de estroma, com a idade, já estão bem estabelecidas na literatura (WATERHOUSE et al. ${ }^{32}$, 1973; SCOTT $^{22}$, 1977a; SCOTT $^{24}$, 1980; DRUMMOND; CHISHOLM ${ }^{11}$, 1984; SCOTT; FLOWER; BURNS ${ }^{27}$, 1987; DAYAN et al. ${ }^{9}, 2000 ;$ VERED et al. ${ }^{31}$, 2000; TAKAHASHI et al. ${ }^{30}, 2002$; $A_{Z E V E D O}{ }^{1}$, 2003). Nossos dados mostram que, nas sublinguais, o fenômeno de substituição com a idade não é diferente das demais glândulas salivares. A distribuição das variáveis "parênquima e estroma total" nas Figuras 25 e 26 destacam melhor a substituição se comparado às figuras onde os componentes foram vistos individualmente (Figuras 19, 20, 21, 22 e 23). A densidade de volume de ductos não influenciou a distribuição da densidade de volume de ácinos (Figuras 19, 20 e 25). 


\subsubsection{Da comparação entre gêneros}

Os valores médios da densidade de volume dos componentes glandulares foram próximos nos dois gêneros (Figura 27 e Tabela 13). Desta forma, não houve diferenças estatisticamente significantes nos vários compartimentos morfológicos: ácinos $(p=0,8938)$, ductos $(p=0,1006)$, estroma $(p=0,3510)$ e tecido adiposo $(p=0,9420)$. O único componente a exibir diferença estatisticamente significante entre os gêneros masculino e feminino foi $o$ dos septos $(p=0,0166)$. Este achado não tem nenhuma justificativa clínica, destoa do conjunto e pareceu-nos puramente casual.

A inexistência de diferenças entre gêneros já havia sido constatada em outros estudos (SCOTT ${ }^{22}, 1977 \mathrm{a}$; SCOTT $^{24}$, 1980; AZEVEDO ${ }^{1}, 2003$ ). Destaca-se, neste contexto, o trabalho de $\operatorname{AZEVEDO}^{1}$ (2003), que já apontava morfologicamente a semelhança nos eventos de envelhecimento em glândulas sublinguais de homens e mulheres.

No entanto, SCOTT; FLOWER; BURNS ${ }^{27}$ (1987) encontraram diferença estatisticamente significante entre gêneros, quanto ao tecido fibrovascular, em glândulas parótidas de indivíduos jovens. Os autores não justificaram esta diferença, apenas ressaltaram que valores igualmente maiores em homens mais velhos não foram estatisticamente significantes. Neste estudo, também foi observada semelhança entre os resultados na densidade de volume de ácinos e ductos.

\subsubsection{Do coeficiente de variação (Erro)}

O grau de precisão do método de aferição das densidades de volume dos diferentes compartimentos glandulares é avaliado através do cálculo do coeficiente de variação. Os valores mínimo e máximo encontrados entre as médias dos componentes foram de 0,75 para os ácinos e 22,89 para o tecido adiposo, respectivamente, tendo ocorrido no grupo I (Tabela 14).

No grupo I (0-30 anos), onde o número de ácinos é elevado, a variação na aferição deste componente foi a mais baixa. Raciocínio inverso pode ser aplicado ao tecido adiposo, observado ocasionalmente neste 
grupo, o que explica um "erro" maior. Todavia, valores até 25 são considerados aceitáveis pela literatura internacional ${ }^{+}$.

\subsubsection{Dos volumes glandular e absoluto por componente}

A análise da Figura 28 mostra que o volume absoluto glandular aumentou a partir dos primeiros anos de vida, estabilizando no grupo II e sofrendo um pequeno declínio no grupo III. Porém, as diferenças observadas não foram estatisticamente significantes entre os três grupos $(H=4,2873 ; p=$ 0,1172 - Tabela 15) e nem entre os gêneros masculino e feminino $(p=$ 0,0933 - Tabela 16).

SCOTT $^{21}$ (1975), estudando indivíduos entre 16 e 95 anos, observou glândulas submandibulares masculinas maiores quando comparadas às femininas, mesmo com a grande variação entre os indivíduos e lados do mesmo indivíduo. Apenas nas mulheres observou redução estatisticamente significante do volume glandular com a idade.

A amostra estudada neste trabalho foi composta por indivíduos a partir de 7 meses de idade. Dos 25 indivíduos do grupo I, 10 tinham idades inferiores a 16 anos e, portanto, estavam em fase de crescimento com volumes mutáveis, ainda não estáveis. Tomando os 16 anos como parâmetro, decidimos desprezar os dez indivíduos abaixo desta idade e refazer os cálculos com os 15 restantes que estavam acima daquela idade. Houve diferenças estatisticamente significantes entre os grupos $(H=15,033$; $p=0,0005$ - Tabela 20). O volume glandular diminuiu 33,73\% entre os grupos I (média $=2,49 \mathrm{~cm}^{3}$ ) e III (média $\left.=1,65 \mathrm{~cm}^{3}\right)(p<0,05)$. Este dado é reforçado pela impressão transmitida por aqueles que participaram das necropsias. Segundo eles*, as glândulas dos idosos tinham volume menor no ato da remoção. Nossos resultados permitem-nos, por outro lado, afirmar que a substituição por estroma com a idade é inferior ao volume do parênquima mais jovem.

\footnotetext{
+ Comunicação pessoal - Prof. Dr. Rumio Taga.

* DAMANTE, J.H. - Professor titular do departamento de Estomatologia - FOB-USP. Orientador da linha de pesquisa. AZEVEDO, L.R. Doutoranda em Estomatologia - FOB-USP de 2000 a 2003. (AZEVEDO $\left.{ }^{1}, 2003\right)$.
} 
TABELA 20 - Volume glandular médio $\left(\mathrm{cm}^{3}\right)$ nos três grupos estudados considerando o grupo I com 15 indivíduos

\begin{tabular}{cccc}
\hline & GRUPO I & GRUPO II & GRUPO III \\
\hline MÉDIA & 2,49 & 2,04 & 1,65 \\
EPM & 0,186 & 0,139 & 0,131 \\
DP & 0,719 & 0,762 & 0,774 \\
\hline
\end{tabular}

Teste de Kruskal-Wallis $(\mathrm{H}=15,033 ; p=0,0005)$

EPM: erro padrão da média; DP: desvio padrão

A atrofia generalizada dos órgãos com a idade é um fenômeno conhecido. Como explicar as tumefações do soalho bucal associadas às glândulas sublinguais, em desdentados, se o volume diminui com a idade e os portadores de tumefação têm idade mais avançada (DAMANTE et al. ${ }^{7}$, 1999; IWAKI FILHO $\left.{ }^{13}, 1999\right)$ ?

A influência da altura de inserção do músculo milo-hióideo nos pacientes com tumefações do soalho bucal já foi destacada como uma das hipóteses (IWAKI $\mathrm{FILHO}^{13}, 1999$ ). É possível que, realmente, não haja aumento de volume da glândula em si, mas sim uma elevação de todo o soalho bucal empurrando a glândula para cima do rebordo alveolar e criando, assim, uma falsa impressão clínica de tumefação.

Analisando a Tabela 17, observamos que as pequenas alterações no volume glandular parecem estar compensadas entre os volumes absolutos dos componentes glandulares. Enquanto a média do volume dos ácinos diminui com a idade, ocorre o oposto com o estroma e o tecido adiposo. Embora os valores não sejam absolutamente iguais, a tendência evidenciada pela diminuição de parênquima e aumento de estroma e tecido adiposo é inequívoca. Não se pode, contudo, afirmar que a substituição aumenta o volume do órgão. Ao contrário, os tecidos conjuntivo e adiposo ocupam menos espaço que aquele liberado pela atrofia acinar. Os tecidos conjuntivo e adiposo não se somam ao parênquima glandular. 


\subsubsection{Das relações parênquima/estroma e ácinos/ductos}

As relações parênquima/estroma e ácinos/ductos foram calculadas a partir dos dados do volume dos componentes. Ambas relações sofreram decréscimo com o avanço da idade (Figuras 29 e 30). Houve diferenças estatisticamente significantes entre os três grupos na relação parênquima/estroma ( $\mathrm{H}=60,118 ; p<0,0001$ - Tabela 18). Já na relação ácinos/ductos, houve diferenças significantes entre os grupos I e III e, II e III $(H=33,548 ; p<0,0001-$ Tabela 19). A relação parênquima/estroma mostra mais claramente as modificações que ocorrem nas glândulas sublinguais com o envelhecimento, ou seja, atrofia e desaparecimento dos ácinos e a sua substituição por estroma sem diminuição significativa no volume glandular. Por outro lado, a diminuição na relação ácinos/ductos, mostra que a atrofia observada no parênquima glandular ocorre por diminuição principalmente no volume e no número de ácinos e que os ductos são mais resistentes.

Os achados desta investigação demonstram que as alterações decorrentes do envelhecimento na glândula sublingual humana parecem ocorrer de forma similar àquelas observadas em estudos anteriores, nas glândulas parótidas (SCOTT; FLOWER; BURNS ${ }^{27}$, 1987), submandibulares (WATERHOUSE et al. $^{32}$, 1973; SCOTT ${ }^{22}$, 1977a), labiais (SCOTT ${ }^{24}$, 1980; VERED et al. ${ }^{31}$, 2000) e palatinas (DAYAN et al. ${ }^{9}$, 2000) humanas. Os resultados também comprovam, quantitativamente, por outro lado, as mesmas alterações com a idade, observadas no trabalho morfológico de AZEVEDO $^{1}$ (2003) e DAMANTE et al. ${ }^{8}$ (2004). 


\section{Conclusões}




\section{CONCLUSÕES}

A partir dos resultados obtidos em glândulas sublinguais humanas, podemos concluir que:

5. ocorre a diminuição do parênquima e o aumento do estroma com o envelhecimento $(p<0,0001)$;

6. há diminuição na densidade de volume de ácinos $(p<0,0001)$ e aumento de ductos $(p=0,0275)$, estroma $(p=0,0275)$ e tecido adiposo $(p<0,0001)$ com a idade;

7. o volume absoluto glandular não se modifica significantemente com a idade entre 0 e 92 anos $(p=0,1172)$, mas diminui entre 16 e 92 anos $(p=0,0005)$;

8. as relações volumétricas entre as várias estruturas glandulares e entre o parênquima e o estroma sofrem modificações significativas com o envelhecimento $(p<0,05)$;

9. não foram observadas diferenças estatisticamente significantes entre os gêneros masculino e feminino quanto a densidade de volume de ácinos $(p=0,8938)$, ductos $(p=0,1006)$, estroma $(p=0,3510)$ e tecido adiposo $(p=0,9420)$. 
Anexos 
ANEXOS $^{\dagger}$

\section{Valores Obtidos para Densidade de Volume}

(DADOS ORIGINAIS SEM TRANSFORMAÇÃO)

GRUPO I

\begin{tabular}{|c|c|c|c|c|c|}
\hline GLÂNDULA & ÁcINOS & Ductos & ESTROMA & T. ADIPOSO & SEPtos \\
\hline 1 & $65,76 \%$ & $1,46 \%$ & $9,71 \%$ & $0,30 \%$ & $22,77 \%$ \\
\hline 2 & $77,10 \%$ & $4,41 \%$ & $3,34 \%$ & $0,55 \%$ & $14,59 \%$ \\
\hline 3 & $71,06 \%$ & $3,43 \%$ & $4,66 \%$ & $14,26 \%$ & $6,59 \%$ \\
\hline 4 & $68,97 \%$ & $4,66 \%$ & $1,43 \%$ & $13,88 \%$ & $11,06 \%$ \\
\hline 5 & $58,24 \%$ & $2,92 \%$ & $21,37 \%$ & $4,77 \%$ & $12,70 \%$ \\
\hline 6 & $78,33 \%$ & $1,78 \%$ & $8,73 \%$ & $0,63 \%$ & $10,52 \%$ \\
\hline 7 & $65,29 \%$ & $2,71 \%$ & $7,20 \%$ & $10,20 \%$ & $14,59 \%$ \\
\hline 8 & $77,34 \%$ & $4,48 \%$ & $6,57 \%$ & $0,33 \%$ & $11,27 \%$ \\
\hline 9 & $72,46 \%$ & $2,02 \%$ & $4,06 \%$ & $4,39 \%$ & $17,07 \%$ \\
\hline 10 & $63,68 \%$ & $8,41 \%$ & $6,53 \%$ & $0,08 \%$ & $21,31 \%$ \\
\hline 11 & $82,64 \%$ & $3,64 \%$ & $3,23 \%$ & $0,18 \%$ & $10,31 \%$ \\
\hline 12 & $86,51 \%$ & $2,32 \%$ & $4,20 \%$ & $0,83 \%$ & $6,14 \%$ \\
\hline 13 & $83,06 \%$ & $5,85 \%$ & $1,74 \%$ & $0,25 \%$ & $9,09 \%$ \\
\hline 14 & $86,11 \%$ & $3,52 \%$ & $1,72 \%$ & $0,05 \%$ & $8,60 \%$ \\
\hline 15 & $79,25 \%$ & $5,37 \%$ & $2,30 \%$ & $0,02 \%$ & $13,06 \%$ \\
\hline 16 & $82,86 \%$ & $3,84 \%$ & $4,29 \%$ & $0,76 \%$ & $8,26 \%$ \\
\hline 17 & $81,81 \%$ & $3,57 \%$ & $3,55 \%$ & $0,13 \%$ & $10,93 \%$ \\
\hline 18 & $82,62 \%$ & $2,00 \%$ & $5,74 \%$ & $0,76 \%$ & $8,89 \%$ \\
\hline 19 & $77,90 \%$ & $1,77 \%$ & $8,31 \%$ & $2,97 \%$ & $9,06 \%$ \\
\hline 20 & $87,09 \%$ & $2,84 \%$ & $1,71 \%$ & $0,45 \%$ & $7,91 \%$ \\
\hline 21 & $77,36 \%$ & $2,45 \%$ & $4,38 \%$ & $6,16 \%$ & $9,65 \%$ \\
\hline 22 & $89,48 \%$ & $1,16 \%$ & $2,71 \%$ & $0,00 \%$ & $6,65 \%$ \\
\hline 23 & $85,57 \%$ & $2,48 \%$ & $2,41 \%$ & $0,24 \%$ & $9,31 \%$ \\
\hline 24 & $74,20 \%$ & $6,31 \%$ & $3,71 \%$ & $3,10 \%$ & $12,69 \%$ \\
\hline 25 & $89,22 \%$ & $0,87 \%$ & $1,77 \%$ & $1,57 \%$ & $6,58 \%$ \\
\hline
\end{tabular}

GRUPO II

\begin{tabular}{cccccc}
\hline GLÂNDULA & ÁCINOS & DUCTOS & ESTROMA & T. ADIPOSO & SEPTOS \\
\hline 1 & $63,09 \%$ & $5,39 \%$ & $12,44 \%$ & $12,27 \%$ & $6,80 \%$ \\
2 & $51,26 \%$ & $10,04 \%$ & $22,93 \%$ & $0,35 \%$ & $15,42 \%$ \\
3 & $62,62 \%$ & $4,41 \%$ & $12,06 \%$ & $9,60 \%$ & $11,32 \%$ \\
4 & $65,84 \%$ & $3,13 \%$ & $11,28 \%$ & $0,58 \%$ & $19,17 \%$ \\
5 & $64,35 \%$ & $7,35 \%$ & $10,57 \%$ & $3,31 \%$ & $14,41 \%$ \\
6 & $68,55 \%$ & $5,52 \%$ & $12,97 \%$ & $1,70 \%$ & $11,25 \%$
\end{tabular}

\footnotetext{
${ }^{\dagger}$ NBR 10719 da ABNT (Associação Brasileira de Normas Técnicas)
} 


\begin{tabular}{|c|c|c|c|c|c|}
\hline 7 & $60,01 \%$ & $4,93 \%$ & $19,16 \%$ & $2,90 \%$ & $13,01 \%$ \\
\hline 8 & $60,75 \%$ & $11,73 \%$ & $13,87 \%$ & $4,90 \%$ & $8,75 \%$ \\
\hline 9 & $46,34 \%$ & $7,18 \%$ & $38,39 \%$ & $0,00 \%$ & $8,10 \%$ \\
\hline 10 & $67,86 \%$ & $5,25 \%$ & $7,42 \%$ & $6,74 \%$ & $12,72 \%$ \\
\hline 11 & $71,07 \%$ & $2,39 \%$ & $14,35 \%$ & $2,25 \%$ & $9,95 \%$ \\
\hline 12 & $71,96 \%$ & $3,81 \%$ & $11,44 \%$ & $2,84 \%$ & $9,96 \%$ \\
\hline 13 & $55,64 \%$ & $6,99 \%$ & $20,60 \%$ & $6,23 \%$ & $10,54 \%$ \\
\hline 14 & $50,97 \%$ & $3,00 \%$ & $25,07 \%$ & $11,80 \%$ & $9,16 \%$ \\
\hline 15 & $48,99 \%$ & $2,38 \%$ & $32,24 \%$ & $5,22 \%$ & $11,17 \%$ \\
\hline 16 & $78,44 \%$ & $4,52 \%$ & $5,56 \%$ & $1,77 \%$ & $9,71 \%$ \\
\hline 17 & $62,68 \%$ & $2,76 \%$ & $13,30 \%$ & $8,61 \%$ & $12,65 \%$ \\
\hline 18 & $67,09 \%$ & $3,30 \%$ & $16,35 \%$ & $6,79 \%$ & $6,47 \%$ \\
\hline 19 & $39,04 \%$ & $4,48 \%$ & $12,22 \%$ & $33,96 \%$ & $10,30 \%$ \\
\hline 20 & $72,82 \%$ & $7,87 \%$ & $4,47 \%$ & $0,48 \%$ & $14,35 \%$ \\
\hline 21 & $79,46 \%$ & $2,38 \%$ & $8,01 \%$ & $1,63 \%$ & $8,53 \%$ \\
\hline 22 & $53,35 \%$ & $6,22 \%$ & $25,72 \%$ & $10,58 \%$ & $4,14 \%$ \\
\hline 23 & $82,34 \%$ & $1,54 \%$ & $8,01 \%$ & $0,45 \%$ & $7,65 \%$ \\
\hline 24 & $77,20 \%$ & $1,92 \%$ & $4,37 \%$ & $2,90 \%$ & $13,62 \%$ \\
\hline 25 & $69,29 \%$ & $2,08 \%$ & $17,10 \%$ & $3,61 \%$ & $7,93 \%$ \\
\hline 26 & $74,34 \%$ & $1,85 \%$ & $8,65 \%$ & $4,95 \%$ & $10,20 \%$ \\
\hline 27 & $65,23 \%$ & $8,34 \%$ & $13,07 \%$ & $3,37 \%$ & $9,99 \%$ \\
\hline 28 & $46,92 \%$ & $6,20 \%$ & $11,96 \%$ & $22,39 \%$ & $12,53 \%$ \\
\hline 29 & $87,47 \%$ & $2,80 \%$ & $2,05 \%$ & $0,53 \%$ & $7,15 \%$ \\
\hline 30 & $75,86 \%$ & $2,78 \%$ & $13,67 \%$ & $0,05 \%$ & $7,65 \%$ \\
\hline
\end{tabular}

GRUPO III

\begin{tabular}{cccccc}
\hline GLÂNDULA & ÁCINOS & DUCTOS & ESTROMA & T. ADIPOSO & SEPTOS \\
\hline 1 & $28,18 \%$ & $1,72 \%$ & $64,22 \%$ & $1,50 \%$ & $4,38 \%$ \\
2 & $23,81 \%$ & $10,67 \%$ & $58,05 \%$ & $0,55 \%$ & $6,93 \%$ \\
3 & $13,17 \%$ & $9,01 \%$ & $24,17 \%$ & $47,60 \%$ & $6,05 \%$ \\
4 & $50,79 \%$ & $6,39 \%$ & $17,81 \%$ & $19,60 \%$ & $5,41 \%$ \\
5 & $62,79 \%$ & $5,83 \%$ & $20,23 \%$ & $2,16 \%$ & $9,00 \%$ \\
6 & $16,44 \%$ & $8,67 \%$ & $59,42 \%$ & $11,41 \%$ & $4,06 \%$ \\
7 & $33,00 \%$ & $7,00 \%$ & $35,16 \%$ & $9,88 \%$ & $14,96 \%$ \\
8 & $64,38 \%$ & $7,47 \%$ & $18,34 \%$ & $0,83 \%$ & $8,98 \%$ \\
9 & $35,05 \%$ & $7,36 \%$ & $34,84 \%$ & $16,85 \%$ & $5,90 \%$ \\
10 & $38,54 \%$ & $10,04 \%$ & $30,38 \%$ & $3,60 \%$ & $17,45 \%$ \\
11 & $40,27 \%$ & $8,24 \%$ & $31,04 \%$ & $4,74 \%$ & $15,70 \%$ \\
12 & $20,71 \%$ & $7,55 \%$ & $31,93 \%$ & $31,02 \%$ & $8,79 \%$ \\
13 & $21,51 \%$ & $0,29 \%$ & $41,71 \%$ & $34,16 \%$ & $2,32 \%$ \\
14 & $68,97 \%$ & $3,28 \%$ & $17,81 \%$ & $2,20 \%$ & $7,75 \%$ \\
15 & $12,01 \%$ & $5,07 \%$ & $54,68 \%$ & $20,69 \%$ & $7,55 \%$ \\
16 & $11,46 \%$ & $2,71 \%$ & $55,93 \%$ & $29,90 \%$ & $0,00 \%$
\end{tabular}




\begin{tabular}{cccccc}
17 & $52,11 \%$ & $5,39 \%$ & $20,52 \%$ & $17,33 \%$ & $4,64 \%$ \\
18 & $30,88 \%$ & $3,75 \%$ & $22,25 \%$ & $33,82 \%$ & $9,30 \%$ \\
19 & $33,53 \%$ & $5,97 \%$ & $51,34 \%$ & $1,57 \%$ & $7,59 \%$ \\
20 & $9,12 \%$ & $1,05 \%$ & $60,43 \%$ & $26,96 \%$ & $2,44 \%$ \\
21 & $5,03 \%$ & $0,67 \%$ & $21,60 \%$ & $67,79 \%$ & $4,91 \%$ \\
22 & $16,74 \%$ & $2,76 \%$ & $27,30 \%$ & $46,12 \%$ & $7,08 \%$ \\
23 & $69,16 \%$ & $2,68 \%$ & $21,74 \%$ & $1,82 \%$ & $4,59 \%$ \\
24 & $4,40 \%$ & $5,71 \%$ & $20,90 \%$ & $68,45 \%$ & $0,52 \%$ \\
25 & $67,11 \%$ & $4,00 \%$ & $10,14 \%$ & $7,64 \%$ & $11,10 \%$ \\
26 & $25,85 \%$ & $9,39 \%$ & $35,79 \%$ & $12,48 \%$ & $16,48 \%$ \\
27 & $46,13 \%$ & $10,68 \%$ & $23,26 \%$ & $12,53 \%$ & $7,40 \%$ \\
28 & $16,17 \%$ & $5,69 \%$ & $26,34 \%$ & $48,39 \%$ & $3,41 \%$ \\
29 & $67,48 \%$ & $2,90 \%$ & $13,06 \%$ & $5,17 \%$ & $11,39 \%$ \\
30 & $4,66 \%$ & $1,60 \%$ & $28,00 \%$ & $64,27 \%$ & $1,47 \%$ \\
31 & $56,02 \%$ & $1,95 \%$ & $25,20 \%$ & $6,62 \%$ & $10,22 \%$ \\
32 & $22,49 \%$ & $10,26 \%$ & $32,11 \%$ & $27,73 \%$ & $7,42 \%$ \\
33 & $32,21 \%$ & $5,95 \%$ & $14,16 \%$ & $42,59 \%$ & $5,10 \%$ \\
34 & $29,54 \%$ & $3,02 \%$ & $26,66 \%$ & $34,44 \%$ & $6,33 \%$ \\
35 & $58,09 \%$ & $3,76 \%$ & $7,95 \%$ & $22,37 \%$ & $7,82 \%$ \\
\hline
\end{tabular}

\section{CÁlCULO do ERRo}

GRUPO I

\begin{tabular}{cccccc}
\hline GLÂNDULA & ÁCINOS & DUCTOS & ESTROMA & T. ADIPOSO & SEPTOS \\
\hline 1 & 1,01 & 11,51 & 4,27 & 25,33 & 2,58 \\
2 & 0,76 & 6,52 & 7,53 & 18,76 & 3,39 \\
3 & 0,89 & 7,43 & 6,34 & 3,43 & 5,27 \\
4 & 0,94 & 6,34 & 11,62 & 3,49 & 3,97 \\
5 & 1,19 & 8,07 & 2,69 & 6,26 & 3,67 \\
6 & 0,74 & 10,39 & 4,53 & 17,56 & 4,08 \\
7 & 1,02 & 8,38 & 5,03 & 4,15 & 3,39 \\
8 & 0,76 & 6,46 & 5,28 & 24,35 & 3,93 \\
9 & 0,86 & 9,75 & 6,81 & 6,53 & 3,09 \\
10 & 1,06 & 4,62 & 5,30 & 51,10 & 2,69 \\
11 & 0,64 & 7,21 & 7,66 & 32,90 & 4,13 \\
12 & 0,55 & 9,09 & 6,69 & 15,30 & 5,47 \\
13 & 0,63 & 5,62 & 10,51 & 28,21 & 4,43 \\
14 & 0,56 & 7,33 & 10,57 & 65,27 & 4,56 \\
15 & 0,72 & 5,88 & 9,13 & 94,59 & 3,61 \\
16 & 0,64 & 7,01 & 6,62 & 15,97 & 4,67 \\
17 & 0,66 & 7,28 & 7,30 & 38,59 & 4,00 \\
18 & 0,64 & 9,81 & 5,68 & 16,04 & 4,48 \\
19 & 0,75 & 10,44 & 4,65 & 8,01 & 4,44
\end{tabular}




\begin{tabular}{lccccc}
20 & 0,54 & 8,19 & 10,61 & 20,72 & 4,78 \\
21 & 0,76 & 8,83 & 6,54 & 5,47 & 4,28 \\
22 & 0,48 & 12,92 & 8,39 & - & 5,25 \\
23 & 0,58 & 8,79 & 8,91 & 28,36 & 4,37 \\
24 & 0,83 & 5,40 & 7,13 & 7,83 & 3,67 \\
25 & 0,49 & 14,99 & 10,43 & 11,09 & 5,28 \\
\hline
\end{tabular}

GRUPO II

\begin{tabular}{|c|c|c|c|c|c|}
\hline GLÂNDULA & ÁcINOS & Ductos & ESTROMA & T. ADIPOSO & SEPTOS \\
\hline 1 & 1,07 & 5,87 & 3,71 & 3,74 & 5,18 \\
\hline 2 & 1,37 & 4,19 & 2,57 & 23,64 & 3,28 \\
\hline 3 & 1,08 & 6,52 & 3,78 & 4,30 & 3,92 \\
\hline 4 & 1,01 & 7,80 & 3,93 & 18,29 & 2,88 \\
\hline 5 & 1,04 & 4,97 & 4,07 & 7,57 & 3,41 \\
\hline 6 & 0,95 & 5,79 & 3,63 & 10,66 & 3,93 \\
\hline 7 & 1,14 & 6,15 & 2,88 & 8,11 & 3,62 \\
\hline 8 & 1,13 & 3,84 & 3,49 & 6,17 & 4,52 \\
\hline 9 & 1,51 & 5,03 & 1,77 & - & 4,72 \\
\hline 10 & 0,96 & 5,95 & 4,95 & 5,21 & 3,67 \\
\hline 11 & 0,89 & 8,95 & 3,42 & 9,23 & 4,21 \\
\hline 12 & 0,87 & 7,03 & 3,90 & 8,20 & 4,21 \\
\hline 13 & 1,25 & 5,11 & 2,75 & 5,43 & 4,08 \\
\hline 14 & 1,37 & 7,96 & 2,42 & 3,83 & 4,41 \\
\hline 15 & 1,43 & 8,97 & 2,03 & 5,97 & 3,95 \\
\hline 16 & 0,73 & 6,43 & 5,77 & 10,44 & 4,27 \\
\hline 17 & 1,08 & 8,31 & 3,57 & 4,56 & 3,68 \\
\hline 18 & 0,98 & 7,58 & 3,17 & 5,19 & 5,32 \\
\hline 19 & 1,75 & 6,47 & 3,75 & 1,95 & 4,13 \\
\hline 20 & 0,86 & 4,79 & 6,47 & 20,17 & 3,42 \\
\hline 21 & 0,71 & 8,97 & 4,75 & 10,89 & 4,59 \\
\hline 22 & 1,31 & 5,44 & 2,38 & 4,07 & 6,74 \\
\hline 23 & 0,65 & 11,18 & 4,74 & 20,74 & 4,87 \\
\hline 24 & 0,76 & 10,02 & 6,55 & 8,11 & 3,53 \\
\hline 25 & 0,93 & 9,61 & 3,08 & 7,23 & 4,77 \\
\hline 26 & 0,82 & 10,20 & 4,55 & 6,13 & 4,15 \\
\hline 27 & 1,02 & 4,64 & 3,61 & 7,49 & 4,20 \\
\hline 28 & 1,49 & 5,45 & 3,80 & 2,61 & 3,70 \\
\hline 29 & 0,53 & 8,25 & 9,68 & 19,27 & 5,05 \\
\hline 30 & 0,79 & 8,29 & 3,52 & 65,90 & 4,87 \\
\hline
\end{tabular}


GRUPO III

\begin{tabular}{|c|c|c|c|c|c|}
\hline GLÂNDULA & ÁcINOS & Ductos & ESTROMA & T. ADIPOSO & SEPTOS \\
\hline 1 & 2,24 & 10,58 & 1,05 & 11,34 & 6,54 \\
\hline 2 & 2,51 & 4,05 & 1,19 & 18,91 & 5,13 \\
\hline 3 & 3,60 & 4,45 & 2,48 & 1,47 & 5,52 \\
\hline 4 & 1,38 & 5,36 & 3,01 & 2,84 & 5,85 \\
\hline 5 & 1,08 & 5,63 & 2,78 & 9,43 & 4,45 \\
\hline 6 & 3,16 & 4,54 & 1,16 & 3,90 & 6,80 \\
\hline 7 & 2,00 & 5,10 & 1,90 & 4,23 & 3,34 \\
\hline 8 & 1,04 & 4,93 & 2,96 & 15,27 & 4,46 \\
\hline 9 & 1,91 & 4,97 & 1,92 & 3,11 & 5,59 \\
\hline 10 & 1,77 & 4,19 & 2,12 & 7,25 & 3,05 \\
\hline 11 & 1,71 & 4,67 & 2,09 & 6,28 & 3,24 \\
\hline 12 & 2,74 & 4,90 & 2,04 & 2,09 & 4,51 \\
\hline 13 & 2,67 & 25,83 & 1,66 & 1,94 & 9,09 \\
\hline 14 & 0,94 & 7,61 & 3,01 & 9,34 & 4,83 \\
\hline 15 & 3,79 & 6,06 & 1,27 & 2,74 & 4,90 \\
\hline 16 & 3,89 & 8,38 & 1,24 & 2,14 & - \\
\hline 17 & 1,34 & 5,87 & 2,76 & 3,06 & 6,35 \\
\hline 18 & 2,09 & 7,09 & 2,62 & 1,96 & 4,37 \\
\hline 19 & 1,97 & 5,56 & 1,36 & 11,09 & 4,89 \\
\hline 20 & 4,42 & 13,59 & 1,13 & 2,30 & 8,85 \\
\hline 21 & 6,08 & 17,08 & 2,67 & 0,97 & 6,16 \\
\hline 22 & 3,12 & 8,32 & 2,29 & 1,51 & 5,07 \\
\hline 23 & 0,94 & 8,43 & 2,66 & 10,29 & 6,38 \\
\hline 24 & 6,52 & 5,69 & 2,72 & 0,95 & 19,30 \\
\hline 25 & 0,98 & 6,86 & 4,17 & 4,87 & 3,96 \\
\hline 26 & 2,37 & 4,35 & 1,88 & 3,71 & 3,15 \\
\hline 27 & 1,51 & 4,05 & 2,54 & 3,70 & 4,95 \\
\hline 28 & 3,19 & 5,70 & 2,34 & 1,45 & 7,46 \\
\hline 29 & 0,97 & 8,10 & 3,61 & 5,99 & 3,91 \\
\hline 30 & 6,33 & 10,99 & 2,25 & 1,04 & 11,46 \\
\hline 31 & 1,24 & 9,94 & 2,41 & 5,26 & 4,15 \\
\hline 32 & 2,60 & 4,14 & 2,04 & 2,26 & 4,95 \\
\hline 33 & 2,03 & 5,57 & 3,45 & 1,63 & 6,04 \\
\hline 34 & 2,16 & 7,94 & 2,32 & 1,93 & 5,38 \\
\hline 35 & 1,19 & 7,08 & 4,76 & 2,61 & 4,81 \\
\hline
\end{tabular}


Referências Bibliográficas 


\section{REFERÊNCIAS BIBLIOGRÁFICAS}

1. AZEVEDO, L.R. de. Alterações microscópicas com a idade em glândulas sublinguais humanas. Estudo post mortem. Bauru, 2003. 97p. Tese (Doutorado) - Faculdade de Odontologia de Bauru, Universidade de São Paulo.

2. $\mathrm{BOSCH}, \mathrm{X}$. et al. Nifedipine-induced parotitis [letter]. Lancet, v.23, n.2, p.467, Aug. 1986.

3. CAMPOS, L.A. Hyperplasia of the sublingual glands in adult patients. Oral Surg., v.81, n.5, p.584-5, May 1996.

4. CASTRO, A.L. Estomatologia. 2.ed. São Paulo: Ed. Santos, 1995.

5. CAWSON, R.A.; BINNIE, W.H.; EVESON, J.W. Atlas colorido de enfermidades da boca. Correlações clínicas e patológicas. 2.ed. São Paulo: Artes Médicas, 1995.

6. CHALKLEY, H.W. Method for the quantitative morphologic analysis of times. J. Nat. Cancer Inst., v.4, p.47-53, 1943.

7. DAMANTE, J.H. et al. Floor of the mouth enlargements related to the sublingual glands in edentulous or partially edentulous patients. J. dent. Res., v. 78, Abstract \#3177, p.503, Mar. 1999.

8. DAMANTE, J.H. et al. Age-related changes in human sublingual glands. A post mortem study. IADR Honolulu, 2004. Disponível na Internet. http://iadr.confex.com/iadr/2004Hawaii/techprogram/abstract_43781.htm

\footnotetext{
* Normas recomendadas para uso no âmbito da Universidade de São Paulo, com base no documento "Referências Bibliográficas: exemplos", emanados do Conselho Supervisor do Sistema Integrado de Bibliotecas da USP, em reunião de 20 de setembro de 1990.
} 
9. DAYAN, D.; VERED, M.; PAZ, T.; BUCHNER, A. Aging of human palatal salivary glands: a histomorphometric study. Exp. Gerontol., v.35, n.1, p.85-93, Feb 2000.

10.DE WILDE, P.C.; BAAK, J.P.; VAN HOUWELINGEN J.C.; KARTER, L.; SLOOTWEG, P.J. Morphometric study of histological changes in sublabial salivary glands due to age process. J. clin. Pathol., v.39, n.4, p.406-17, April 1986.

11. DRUMMOND, J.R.; CHISHOLM, D.M. A qualitative and quantitative study of the ageing human labial salivary glands. Archs. oral Biol., v.29, n.2, p.151-5, 1984.

12. FULOP, M. Pouting sublinguals: enlarged salivary glands in myxoedema. Lancet, v.2, n.2, p.550-1, Sept. 1989.

13. IWAKI FILHO, L. Tumefações do soalho da boca relacionadas às glândulas sublinguais em desdentados parciais e totais. Estudo clínico e microscópico. Bauru, 1999. 91p. Tese (Doutorado) Faculdade de Odontologia de Bauru, Universidade de São Paulo.

14. KOMESU, M.C. et al. Alterações morfológicas da glândula submandibular do rato determinadas pelo envelhecimento. Rev. Fac. Odontol. Ribeirão Preto, v.23, n.2, p.79-88, jul.-dez. 1986.

15. KOMESU, M.C. et al. Estudo morfométrico das alterações da glândula submandibular do rato determinadas pelo envelhecimento. I. Ácinos. Arch. Cent. Est. Cur. Odontol., v.24, n.1/2, p.9-26, jan.-dez. 1987. 
16. KOMESU, M.C. et al. Estudo morfométrico das alterações da glândula submandibular do rato, determinadas pelo envelhecimento. II. Ductos. Rev. Fac. Odontol. Lins., v.2, n.1, p.6-10, jan.-jun. 1989.

17. MINTZ, G.A.; MOORADIAN, A.D. Age-related changes in rat sublingual salivary gland morphology. Gerodontology, v.6, n.4, p.137-44, Winter 1987.

18. NEVILLE, B.W. et al. Patologia oral maxilofacial. Rio de Janeiro: Guanabara Koogan, 1995.

19. PARDINI, L.C. Estudo morfométrico da glândula submandibular do camundongo. Comparação entre sexos. Bauru, $1985.146 p$. Dissertação (Mestrado) - Faculdade de Odontologia de Bauru, Universidade de São Paulo.

20.SASHIMA, M. Age-related changes of rat submandibular gland: a morphometric and ultrastructural study. J. oral Pathol., v.15, n.10, p.50712, Nov. 1986.

21. SCOTT, J. Age, sex and contralateral differences in the volumes of human submandibular salivary glands. Archs. oral. Biol., v.20, n.12, p.885-7, Dec. 1975.

22. SCOTT, J. Quantitative age changes in the histological structure of human submandibular salivary glands. Archs. oral Biol., v.22, n.3, p.221-7, 1977a.

23.SCOTT, J. Degenerative changes in the histology of the human submandibular salivary gland occuring with age. J. Biol. Buccale, v.5, n.4, p.311-9, Dec. 1977b. 
24. SCOTT, J. Qualitative and quantitative observations on the histology of human labial salivary glands obtained post mortem. J. biol. Buccale, v.8, n.3, p.187-200, Sept. 1980.

25. SCOTT, J. Structure and function in aging human salivary glands. Gerodontology, v.5, p.149-58, 1986.

26. SCOTT, J.; BODNER, L.; BAUM, B.J. Assessment of age-related changes in the submandibular and sublingual salivary glands of the rat using stereological analysis. Archs. oral Biol., v.31, n.1, p.69-71, Jan. 1986.

27. SCOTT, J.; FLOWER, E.A.; BURNS, J. A quantitative study of histological changes in the human parotid gland occurring with adult age. J. oral Pathol., v.16, n.10, p.505-510, Nov. 1987.

28. TAGA, R.; SESSO, A.; PARDINI, L.C. Avaliação da homogeneidade da amostra em morfometria. Rev. Fac. Odontol. Bauru, v.6, n.4, p.57-60, out./dez. 1998.

29. TAGAWA, S. et al. Adenomatoid serous hyperlasia of sublingual gland. A case report. Oral Surg., v.82, n.4, p.437-40, Oct. 1996.

30. TAKAHASHI, S. et al. The roles of apoptosis and mitosis in atrophy of the rat sublingual gland. Tissue Cell, v.34, n.5, p.297-304, Oct. 2002.

31. VERED, M.; BUCHNER, A.; BOLDON, P.; DAYAN, D. Age-related histomorphometric changes in labial salivary glands with special reference to the acinar component. Exp. Gerontol., v.35, n.8, p.1075-84, Oct. 2000. 
32. WATERHOUSE, J.P. et al. Replacement of functional parenchymal cells by fat and connective tissue in human submandibular salivary glands: an age-related change. J. oral Pathol., v.2, n.1, p.16-27, 1973.

33.WEIBEL, E.R. Stereological principles for morphometry in electron microscopic cytology. Int. Rev. Cytol., v.26, p.235-302, 1969. 
Abstract 


\section{ABSTRACT}

\section{Age-RELATED CHANGES IN HUMAN SUBLINGUAL GLAND. A QUANTITATIVE STUDY}

The aim of this study was to evaluate quantitative morphological ageand gender-related changes in human sublingual glands. Ninety right human sublingual glands from necropsies were distributed by gender and age groups for morphometric analysis of the glandular components and volume. Individuals with ages ranging from 7 months to 92 years were divided into Groups I (0-30 years), II (31-60 years) and III (61-92 years). The quantifications were realized under light microscopy at x40 using a Kpl ocular x8 with a graticule constituted by 100 symmetrical points. The proportional volume of acini, ducts, stroma, adipose tissue and septa were counted on fifty one histological fields for each gland, selected by systematic sampling. The proportional volume of acini was reduced by $56.35 \%(p<0.0001)$ and by $35 \%$ in the septa $(p<0.0001)$, being replaced partly by an increase of $59.79 \%, 517.82 \%$ and $738.36 \%$ in the proportional volume of ducts $(p=$ $0.0275)$, stroma $(p<0.0001)$ and adipose tissue $(p<0.0001)$, respectively. The glandular volume decreased, on average, 33.73\% $(p=0.0005)$. No significant difference was observed between genders ( $p>0.05)$. The decrease of parenchyma is accompanied by an increase of stroma with aging. 